University of Massachusetts Amherst

ScholarWorks@UMass Amherst

Doctoral Dissertations 1896 - February 2014

$1-1-1935$

\title{
Factors influencing the rate of decomposition of different types of plant tissue in soil, and the effect of the products of plant growth
}

Major Franklin Spaulding

University of Massachusetts Amherst

Follow this and additional works at: https://scholarworks.umass.edu/dissertations_1

\section{Recommended Citation}

Spaulding, Major Franklin, "Factors influencing the rate of decomposition of different types of plant tissue in soil, and the effect of the products of plant growth" (1935). Doctoral Dissertations 1896 - February 2014. 904.

https://doi.org/10.7275/pzk2-c774 https://scholarworks.umass.edu/dissertations_1/904

This Open Access Dissertation is brought to you for free and open access by ScholarWorks@UMass Amherst. It has been accepted for inclusion in Doctoral Dissertations 1896 - February 2014 by an authorized administrator of ScholarWorks@UMass Amherst. For more information, please contact scholarworks@library.umass.edu. 
ANO IHE EYECT OE THE PRODUCTS ON PLA 
IAPR $8 \quad 1983$
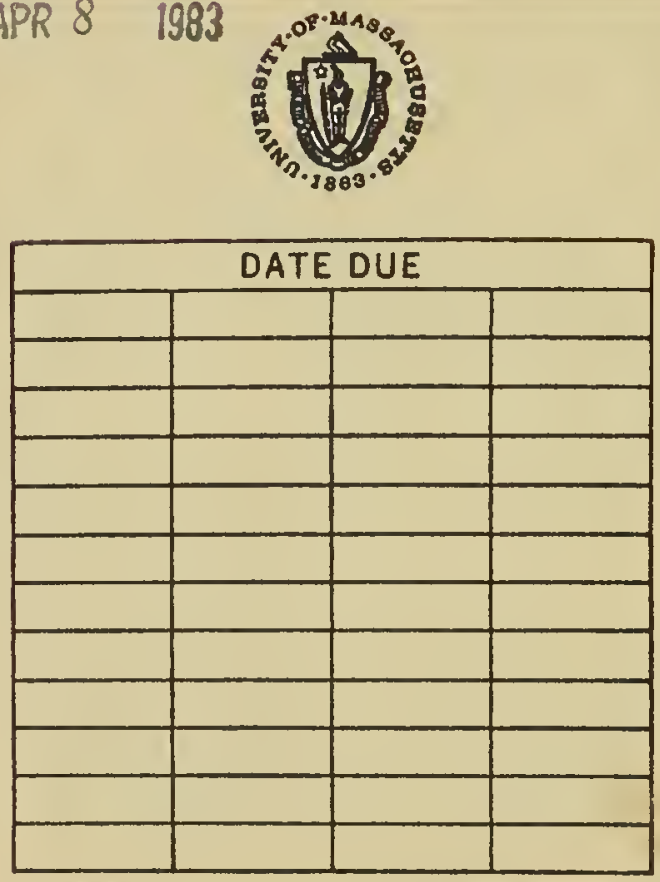

UNIV. OF MASSACHUSETTS/AMHERST LIBRARY MORR

LD

3234

M267

1935

S739 
FACTORS INILUANCING THE RATE OF DECOMPOSITION OT DI RTRENT TYPES OF DLANT TISEUE IN SOIL, AND THE EHTECT OF THE PRODUCTS ON PI ANT GRONTY

By

Wajor Franklin Spaulding

Presented in Partial Fulfilment of the Requirements for the Derree of Doctor of philosoohy at the Massachusetts State College, Amherst, Lassachusetts, May 1935. 
I. Introduction

III. Fieviev of 11terature urion the subject 6

4. Organic matter in solls 6

1. Source 8

2. Function 9

3. Value 9

4. Decomposition

a. The sole of cellalose 10

b. The role of pentosan 13

c. The role of Soluble material 14

d. The vole of nitrogen 15

e. The rolo of 11gain 16

f. The effect of crylug decunposit1on

g. Sol1 acidity ans decomposition 17

B. Needs a fertilizers

C. Summary of facts al ready established and recorded in IIterature upon the subject

IV. Bxperimental procedure for the determination of new facts: results thereof

$\begin{array}{ll}\text { A. Metind } & 26 \\ \text { P.P-eparation of materials } & 27 \\ \text { C. Determinations } & 28 \\ \text { D. Results } & 29\end{array}$

7. Discussion 58

VI. sumbary 68

VII.BIbllograoby 70

VII.Appond1x 76 


\section{ACKMOILEDGEMENTS}

It is a pleasure to make grateful acknowledgement to Dr. Valter S. El senmenger. Head of the Department of Agronomy of the Massachusetts State College, for his suggestion of a subject and for his continued interest and ald throughout the experiment; to Dr. Arthur B. Beaumont, Professor of Agronomy, and to the other instructors and the graduate assistants in the Department of Agronomy for their contributions of valuable information and kindly attention: to Professor orton I. Clark, advisor in minor studies: and to other member of the Department of Botany for assistance in the identification of planta: to Dr. Harry N. Glick, advisor in minor studies: and to other members of the Department of Education for sound advice: and to Mr. Philiip H. Snith of the Massachusetts Exper1ment Station. for the use of the mills in which samples were ground. 


\section{INTRODUCTION}

This study is deroted particularly to decomposition of decaying plants which yield the fertilizing constituents so necessary to the proper growth of other plants: and 1 t will become evident that the rate of decomposition of a plant is governed by the proportion in it of carbohydrates to nitrogenous comoounds, and that the proportion of carbohydrates to nitrogenous compounds in 1 ts make-up depends, in turn, uron the tyoical chenical make up of the species and unon the stage of growth of a plant at the time it is cut dom and left to decay. (The pronoztions of pentosan and nitrogenous compounds in various plants might be made the basis of a classiflcation of plants. Bor, although, there appears not to be a clear increase of nitrogenous content in the evolutionary series -- fungl have a small nitrogen content, for exemple: ferns show somewhat larger propor tions: and the dicotyledons have st1ll more: but with the monocotyledons there appears a diminution of nitrocenous content: -- yet the proportion of pentosans rises steadily bhrough the series.)

Generally speaking the older the nlant, the larger the proportion of carbohydrates in 1ts comosition: and the carbohydrates resist decomposition under the chemical influences of fungl, bacteria, and enzymes for longer than nitrogenous compounds. Furthermore, a large ratio of carbohydrates to nitrogenous comounds delay the time at which the latter -- the fertilizing constituents of the decaying plant -- are avall- 
able for the sustenance of other nlants: for so long as the bacteria and fungl of decay find carbohydrates to feed unon, they w111 come between the growing plant and the nitrogenous compounds in order to consume these latter in themselves. 


\section{OBJECT}

The object of the investigation was to establish by experimental methods principles by which the characteristics and relative values of natural fertilizer (humus) could be estimated in advance of use from their known or discoverable chemical constituents. Such principles would help the agriculturist to maintain the fertility and increase the yield of his land by proper use of his om resources rather than by recourse to commercial fertilizers. With this principal object are combined certain incidental objects growing logically out of the results of the investigation.

In more detall these objects may be stated thus:

1. To discover the rates of decomposition in both soil and sand cultures of various nlants widely used by agriculturists, this rate to be determined in two distinct ways:

a. By determining the total content of carbon, nitrogen, pentosans, and I1gnic acid of each plant at a certain stage of growth: and then determining the amount of amronia and nitrates liberated in the soll or sand culture at'glven intervals during the period of rotting by the various plants.

b. By determining the total content of carbon, nitrogen, pentosan, and $11 \mathrm{gnic}$ acid of each plant at a certain stage of growth: and estimating the rate at which armonia and nitrates are successively 11 berated by 
the various plants in the 8011 or sand culture by their effects upon the growth of barley. In both these methods of determining the rate of decomposition, the following factors were kept constant for all samples and tests:

(1) the significant chemical constituency of soil and sand cultures: and (2) the amount of nitrogen in each sample of plant tissue left to decay (whatever the total bulk of the sample). The first constant was the result of determinations of the amount of nitrogen and carbon in the soll cultures (none of either was pernitted in the sand cultures): the second constant was the result of determinations of the percentage of nitrogen normally present in each of the samples which were to be rotted in the cultures. But in method (a) the amount of ammonla and nitrates liberated vere measured in the laboratory: while in method (b) the amounts of ammoni.a and nitrate liberated were measured by olant growth in the greenhouse.

2. To compare the relative proportions of certain constituents (especially pentosans) of the plants with their relative nositions in classifications of Bessy, Clements, and Conrad, who arrange plants in an evolutionary series determined by morphologlcal rather than chemical considerations: that is, to show a correlgtion between cassification of plants in accordance with their relative contents of ventosans or nitrogen and classifications in accordance with the evolution of their forms. 
3. To determine the relation of the nitrogenous content of a plant to the proportion of silica and lime in the tissue thereof.

4. To show that correlation (either positive of negative) exist among all the characteristics of plants studied in this experiment.

a. Rates of decomoosition (especially liberation of ammonia and nitrates).

b. Rates of beneficial effects of these olants when allowed to rot, upon other living olants.

c. Proportions of nitrogenous compounds to carbohydrates (ospecially pentosans and lignic acid) in the original make-up of plants.

d. Proportions of silica and lime in the tissues of plants.

ब. Classifications of plants in evolutionary series. 


\section{IITERATUHW REVIEW}

When the agricultural sciences began to energe in a recognizable form at the beginning of the last century, the importance of organic material to soll fertility was already known and penerally accepted. Ilumus, the decorposed residue of plants and animals, was supposed to be the direct food of plants. The Netritihe effect of this residue, though generally known to agriculturists, was not oreclsely demonstrated in the laboratory unt11 about 1838. This demongtration aroused 1nterest, but was so on overshadored by the famous pronouncement of Leibig in 18ito. "that crops in a field increase or decrease in exact proportion to the increase or decrease of mineral substances conveyed to them in manure", and by the ravid development on the part of Lawes and filbert of the Rothamstead Experiments in nutrition of plants.

One of the essential differences between a soll and a mass of rocky fragments lies in the organic content of the former. Organic matter Is necessary to that chemical decomosition of minerals (usually in the form of rocks) which produce a soll capable of growing crops successfully. The physical condition of the soll also depends largely on the oresence of organic matter. In an average soll there w1ll be found orgaric matter existing in an almost infinite number of stages of decomosition, organic matter which includes not only all complex compounds contained in the as yet unspoiled regetable and animal tissue, but also those simpler compounds of which the partially decayed portion of such material is composed. The source of practically all organic matter is nlant-tissue. Iyon 
and Buckman (26) demonstrate the prenonderance of plant-tissue over an1mal-tissue by assuming one bacterial cell to weigh .000 .000 .002 milligram. and assuming further that there were some $100,000,000$ such organisms in each gram of soll: even at this density of bacteria only 400 to 800 pounds of the total welght $(2,000.000$ pounds) of an acre of six inch soil is made up of microscoplc life. Another 1200 to 1600 pounis of molds. fungl, algai, actinonycea, insects, and eanthrorms. But the remainder of the roughly 400.000 pounds of organic material in a soll weighing $2,000,000$ pounds to the acre (of six inch depth) consists of plant-tissue in various stages of decay. In short, al though the bacterla perform a very 1mortant function in the moking of a fertile soll, they actually compose a very small fraction by weight of 1 ts organic content. The much larger proportion of plant-tissue is made un partly of the exposed portion of vegetation: and the remainder is the result of root extension and subsequent decay. Since the organic matter in soll has its orgin very largely in the higher plants, it is advisable to consider the general chemical nature of such plants. About 75 percent of the average green plant is vater. The remalning 25 percent is made up roughly of carbon, oxygen, hydrogen and mineral materials in the approximate ratio of 6-6-1-1. (As can be seen from the partial analysis recorded in Table I of some few plants, the preponderant part of normal plant-tissue is carbon). The chemical conatituents of plants are usually more spectefcally classified under the following heads: (I) Carbohydrates, which include sugars, starch, cellulose, lignins, imulin, gums, pectins, and pentosans: (II) fixed oils and waxes, which include castor 011, com o1l, cottonseed 011, linseed oil, and the like: (III) volatile oils and resins, which include such olls as those of 
mastard, cloves, and peppernint, as well as such related meterials as rosin, myrrh and balsam: (IV) orgenic acids and their salts, such as citric, malic, tannic, and tartaric acid: and ( $\gamma$ ) nitrogenous compounds such as nitrate anmonias, amides, amminio-acid, alkaloids, and proteins. Some of the compounda of the first grour are unusually resistant to decomosition: for although sugars and starches disapnear fairly soon, the other cormound 1 isted under this heading decompose slowly. If gnin, indeed. is by far the most resistant of all the constituents of a plant, being the orincipal contributor to humas.

of the five groups, the nitrogenous comoounds are probably the most complicated chemically, for they contain not only carbon hydrogen, oxygen, and nitrogen, but also practically all of the mineral elements such as sulfur, phosphorus, celclun, and iron that exist in the nlant. (The nitrogenous comoounds are probably the most comnlicated chemically because the molecular weight and exact comnosition of many of them are not get certainly established). To be sure, the nitrogenous compounds are not all equally comlex: there are, for examnle, simole proteins such as globulins, albumin, and protamines, besides such derivative proteins as proteose, and peptones. In addition to all these, there is a host of other nitrogenous corpounds that have no small influence on the composition of the soll. AII these comounds exist in the living forms, especially of plants: which tend to accumlate in varying anounts in the umper level of the soil, and are present in all stages of decomposition and of soluility. 413. the chemical transformations in the soil thus far referred to are brought about by the microorganisms which are normally present in soils, and which are lnown to brino about or influence indirectly nunerous physical and cherical changes therein. 
The average of analyses shows that in ordinary fertile soils 95 percent of the nitrogen, 33 percent of the phosphorus, and appreclable amounts of the potassium, sulfur, and calcium vhich it contains are embodied in the organic matter. In other rords, by far the most important natural source of the nitrogen avallable to the farmer for the production of crops is plant-tissue.

But the function of organic matter is cumulative, for when the plant decomoses, it returns to the soil not only the mineral nutrients that it has taken therefrom and utilized by metabolism, but also carbohydrates which with the aid of sunlieht, it has synthesized from the carbon dioxide of the air. When the plant decomposes, the carbon thus synthesized serves as a source of energy for organisms of the soll that tie up atmospheric nitrogen and return it to the soil. Consequently, the vlant yields, upon decomposition, not only the nitrogen it extracted from the soil as it grew, but, through bacteria feeding on its carbon, also niteogen from the air.

Because the restdue of plants increases the capacity of soll to hald water, retards erosion, absorbs (by means of the acidoid colloids in organic material) the ion of mineral elements which would be otherFlse leached out of the soil, and reduces both the plasticity and the cohesion of soils, plant-tissue helps in still other ways to form and maintain the agricultural usefulness of soll. All these ourooses are served as vell by plants that grow out of season or that are otherwise economically worthless as by plants which are grom to be used as fertilizer. 
Scott (54), Collison and Conn (7), Nerton and Daniloff (3), and Gilbert and Pember (13) have all noted that when traw containing little nitrogen and much cellulose was apnlied to the soll, there resulted a diminution of nitrates, with a consequent falling off in the yield of crops: but that these effects could be overcome by the addition of sufficient nitrates in the form of nitrogen and manure.

Doryland (11) stated that a given soil can absorb and hold only so much ammonia and nitrate: that when it is saturated, attempts to force more of these compounds into it are vain. But he found, too, that the addition of dextrose or straw temorarily increased the power of the soll to absorb ammonia and nitrate: and when large quantities of wraw were added to the soll, there was a marked increase in this nower. Although their effect is less marked the residues of plants other than the small gains affect the soil in the same way.

Patrick (140) found that the amount of carbon dioxide evolved from a soll fertilized with plant tissue reflects the relative carbon-nitrogen ratios of the plants used: timothy (which has a high proportion of carbon): and corn gave off more than clover (which has a still smaller proportion of carbon). But when fertilizer was added to a neutral soll in such quantities as to insure an equal anount of carbon in the several samples, the total evolution of carbon-dioxide was much greater from soil treated with clover than from soll treated th timothy to make Its nitrogen-carbon ratio the same as that of clover, the timothy plus the sodium-nitrate invariably yielded more free nitrate than did the clover. 
W11son (67) explained the depression of nitrate in solls when timothy and clover were turned under as follows: carbon-dioxide evolution followed the growth of organisms, whlch was greater under clover soon after tuming under, but soon dropped, mereas the growth of organisms where the timothy was tumed under were not so rapid, but were more prolonged. The decomposition of timothy extended over a longer period of time than did that of the clover residue.

Norman (38) reported that carbon-dioxide closely paralleded the production of heat, and heat production was shown to corresnond to a ravid Ios: of hemicellujoses. Patricik (39) in studying the influence of crop residue on nitrate found that in the roots and stubble of sweet clover ther's was added 6144 pounds wh a carbon nitrogen ratio of 22.9:1. timothy 12652 pounds with a carbon nitrogen ratio of $81: 1$, corn 978 pounds with a carbon nitrogen ratio of $58: 1$. He observed that the carbon-dioxide evolution was in the order of the carbon-nitrogen ratio, timothy, corn and clover. Hill (19) found that the dopression of crop growth from the addition of cellulose to the soil was in proportion to the amount of cellulose added. Varying the amount of nitrates added up to 8 tons did not counteract these 111 effects. Rye in a green stage depressed growth on a heavy clay soil and gave in increase on a more open type of soll which was mell aerated. Corn Jields wore depressed over a period of 12 years where rye was tumed under, and com and wheat gave a much saller yield where clover and soybeans were cut for hay than where they were turned under. The carbonnitrogen ratio was much wider in non-legumes than it was in legurnes, and decay was much slower.

Viljoen and Fred (60) reported that the unfavorable action of wood on plant growth is due to a lack of nitrates in the soil. This lose 
may be due to a greater assimilation of nitrates by soll mlcro-organisms. Diminution of nitrification is caused by a groun of organisms which make use of cellulose, rather than an inhibition of nitrification.

Salter and Green (1:8) reported that the accumulation and losses of organic material are affected by the nature and size of the crop in fleld soils. Corn is about twice as destructive of organic carbon and nitrogen as is a crop of wheat or oats.

Smolik (56) found a relative accumalation of fats, vaxes, and oils to take place in the humification of alfalfs roots and tops. The amount of soluble protein, sugars, amino acids and starches decrease. Hemicalluloses decrease almost half and celluloses 22 percent. Proteins in the green parts as well as the roots decrease, but 1 ignins and 11 oids increase considerably.

Heck (18) found that when energy material was simnle, decomoosition Is largely bacterial. With the liberation of large amounts of nitrate nitrogen, when it is of a high cellulose content, the action is to a great extent fungus, with the liberation of little or no mineral nitrogen. The structure of the carbonaceous energy-materlal governs somewhat the type of decomposition curves and the mount of nitrogen liberated as nitrate. Decomosition 1 s rapid and their effects soon lost if simole: if they are of a hioh cellulose content, the decompositionis much slower and continues over a longer period. He also found that the nitrogen content of fungus tissue was influenced by the nitropen content of the substrate. The decrease in the amount of fungus tissue begins when its carbon nitrogen ratio rasches 10 or 32 to 1 . The average percentage of nitrogen for field forms of funms tissue is 4 percent and that of carbon 10 to 4 li percent. Rudolf (116) found that soil algne acted as indicators of soll properties. 
He drew his conclusions from a study of the algae present in the end in like solls over a period of 13 years which had the same fertilizer treatment. The treatment was as follows: no fertilizer, complete fertilizer. nitrogen, and phosphorus, nitrogen and potash, ohosphorus and potash. Ee found that the different types of algae in the soils were different for the different treatments. The plot recelving the corulete fertilizer contained 26 times as many algae as the unfertilized plots. Whe former had 43 different tyoes where the latter had only 9.

Nornan (38) found that the distribution and arrangement of hemicelluloses in plant tissue are not shlelded so as to be hindered in their attack by microorganisms as in the case of cellulose, by the presence of a more resistant Iignin barrier.

\section{ROLE OF PENTOSAT}

Redge(44) found in studying the decomosition of rice, oats, wheat, barley, straw, rushes, corn, and white ash that if pentosan are much in excess of 11 gnin, the material will be easily dscomposed, the rate decreasing as the ratio to lignins decreased. A high lignin content of any cellulose material is detrimental to deformosition. Pentosans form the imoortant microbial food and may be assumed to control decomposition of a material.

Schmidt and others (49) found that about 50 percent of the pentosans of corn was destroyed in 100 days, and about 35 percent of that of rye steaw in about 300 days. Fraps (12) In studying the organic constituents of the soil reported that the average percentage of pentusans increased With the average nitrogen content of the soll. They are sliently higher 
in the surface than in the subsoil in proportion to the nitrogen content. Pentosans in cotton seed meal disapneared rapidly from the soll durine the first week, and at the end of the eighth week 7 percent of the original pentosans were oresent: from sudan grass 31 percent: from rlce bran 61 percent, from sheep excrement 75 percent.

\section{THE INTLUNNCE OF SOLURLE BATERI IL OH DEOMPOSITION}

Martin (3) determined the decomposition of alfalf a and sweet clover at 30-210- and 270 day intorvals after incorporating thein in the soil and mensured the rate of decomposition as indicated by carbon-dioxide evolution and nitrate accuralation. Plant tissue low In nitrogen jielded Iittle anmonia and nitrogen, even though decay took place. Jo found that fat in elfalfa and corn stalis decomposed quicicly whlle fat in straw resisted disintegration. More than 50 percent of the cold water soluble fractions (sugar anino acids, soluble protein, starches, organic acids, ash, etc.) had gone in 30 days in alfalfa tops and was noarly comolote in 90 days. In sweet clover the decrease ras not so rawld and at the end of 9 months was not as complete as was in alfalfa at the ond of 90 days. Vaksman(52) found that the removal of the alcohol ani water soluble fractions had but little effect on the decomsosition of barley straw but greatly reduced the decomposition of alfilfa meal. He found further from the study of ryo at different stages of growth that there was a gradual decrease of the nitrogen, ach, and fa' content al so of the water soluble portion with an advance in age, and a gradual increase in the content of 11 gnin, pentosans, and cellulose. Ie concluded that the rate of decomposition devends unon the amount of witer soluble constituents, 
nitrogen, and lignin content.

Whiting and Richmond (66a) reported that the first season's growth of biennial white sweet clover contalned less nitrogen than the leaves and stems, though they nitrified more readily. He exolained this on the basis of the higher water soluble nitrogen content.

\section{THE ROLE OT NITROGEN}

Shunk (55) found that the addition of nitrates speeded up the decomposition of cellulose, as evidence by the evolution of carbon-diox1de. This increase was probably due to an increase in fungus activity. He is of the opinion that the decomposition of cellulose depends on the avallable nitrogenous content. The work of Martin (3) showed an increase in the number of molds from the addition of alfalfa in excess of that of sweet clover. Tenny and haksman (61) report from their study of corn stalks, rye straw, oak leaves, and alfalfa plants that the rate of decomposition was influenced by their chemical composition. Plant materials w1 th a nitrogen content between .2 percent and 1.7 percent their decompom sition was marked by an increase in crude protein content, due to the synthesizing activities of the soil organisms. They further report that the adaltion of avallable inorganic nitrogen salts hastens the decomposition of celluloses and hemicelluloses. The rapidity of liberation of nitrogen in an available form depends upon the nitrogen content of the plant.

\section{THE ROLF OF IIGNIN}

Iranoff and $\mathrm{Z}_{\text {wetkoff }}$ (24) found that addition of lignin to proteln being decomposed by pure cultures of bacteria and fungt checked 
the decomposition considerably, due to the formation of comound that are resistant to decomposition by bacteria. Waksman (63) found that of mong the various ingredients of such materials as straw the lignins are the most resistant to the action of soll fungt and bacteria. The accumalation of $11 \mathrm{gnin}$ in the soll accounted for a large part of the soil humus which was formed as a result of the decomposttion of straws. The removal of the lignin from straw and alfalfa meal increased the rate and the amount of decomposition.

Tenny and Maksman (61) found from their studies of the decomoosition of corn stalks, rye straw, oak leaves, and alfalfa plants under opt1mum temperature and moisture after 12 to 14 months the residue possessed all the conditions and properties of soll humus. This humus was made up of lignin or modified 11 gnin complexes largely of plant ortgin: of protefns and other complex organic nitrogenous compounds largely of microblal origin: of a small amount of cellulose undergoing decomoost tion and of varying concentrations either in the process of decomposition or nroducts of decomposition.

Boruff and Buswell (3) studied the anaeroblc fermentation of 11 gnin from cornstalks and reported that after 136 days pentosans had Permented 54 percent, cellulose 57 percent, and I1gnin 42 percent. After 600 days pentosans 71 percent. cellulose 85 percent, and lignin 54 percent. He concluded that 1 solated $11 \mathrm{gnin}$ fermented very slomly and incompletely under aeroblc conditions.

Pussell (47) gives the comparative percentages of carbon in plant constituents as follows: Sugars and starches 40 percent

Colluloses and hemicelluloses 45 percent Fats, waxes, o1ls, 45 to 60 percent If gnin 63 percent 
Based on the carbon content the lignins rould be the last to decompose.

\section{THE ERFECT OF DRYING}

Whiting and schoonover (65) found that the drying of green manures retarded the rate of decomposition as evidenced by ammonification and nitrification, and carbon-dioxide evolution in both green house and laboratory experiments. Green clover projuced nitrates very rapidly with a maximum transformation of 35.8 percent at the end of 43 days, while the dried yielded 15.7 percent for the same period. Eutchinson and M1111gan (2la) reported that at the end of 8 weeks green manure from Crotaiaria juncea had nitrified 68 percent, dried for 24 hours 45.3 percent, dried 48 hours 39.1 percent. H111 (19) reported that the drying of green manures retarded the decorposition as evidenced by the carbon=ioxide ovolved during the first ten days. This retardation was thought to have been due to the soluble hemicelluloses and other nolysaccharides having been chenged to less soluble forms.

\section{SOIL ACIDITY AND DECOMPOSITION}

Thom and smith (59) found that the total number of microorgenisms in a limed soil to be about 2 to 3 times that of an acid soil. Organic materials break down by aerobic action, which involves enormous mumbers of bacteria fungl and other orgenisms, without correlated effects upon the micro-nopulation of the underlying soil. Green manures olored into the soil in good tillable condition are broken down princiaplly by bac terial activity. Growing root systems surrounded by very narrow zones of microbic activity give acialty tests at least partialig independent of adjacent soil, hence present biological conditions are determined by their om acidity, rather than that of the soil. 
Jensen (26) submitted a group of organic materials with a carbonnitrogen ratio from 1 to 85 , to 1 to 10 , to nitriflcation tests in acid and alkaline soll for six months. In acid soll only pea meal with a carbon-nitrogen rat1o of 13.3 to 1 showed an increased in inorganic nitrogen over the control: in alkaline soll the limit above which no nitrification in six months was 26-1. Below this limit the rate of nitrification increased rapidy with decreasing carbon nitrogen ratio. All of these materlals tended to increase the content of "alpha" humas but not to the same extent: more was produced in alkaline than in acid soil. The mycelium of Polyporus contains a fraction possessing the properties of humlc acid. Iich in nitrogen but devoid of methoxyl which persists in the so11. The carbon nitrogen ratio is a factor which exerts an infinence on nitrification as profound as that of the soil reaction.

Aso and Yoshlda (1). found that the decomposttion of green manures in soils of ph of 5.30 and low in water soluble phosphorus was increased by apolications of superphosphate or notassium sulfate. The affect of the former was the greater.

\section{WEEDS AS FERTIIIZERS}

All plants during the process of their growth extract from the earth and air such elements of food as they may require for their subsistence, or if they fail to do so, die or fall to reach maturity. It is just as essential for weeds to be properly fed as it is for crop plants as far as olants themselves are concerned. They extract from the soll thelr due nortion of those food ingredients necessary for proper growth and productiveness of paying crops. If these weeds are burned or removed from the soll the question naturally arises as to the how, the 
when, and the what is the best method for retuming these elements that have been removed from the soll by vegetation that is useless, except from the standpoint of prevention of erosion and the tying up of plant food elements as organic matter that might have been lost to the soil.

In the case of many of the well established grasses and legumes they are cut and fed to livestock and then returned to the soll as barnyard manure, but in the case of the useless weeds that are unpalatable to livestock this has not been practiced.

Every plant, no matter of what nature, that is gathered and removed from the fields in which it grew, takes with it more or less of the food elements needed by the next plants to be grom thereon. In order that the natural fertility of the soll be maintained and that the soll fertility elements be preserved for crops yet to follow. It is essential that we return to the soll not only the principal nutrient losses, but that other factors affecting plant growth be properly maintained. Comercial fertilizers alm in general to return to the soil the three essential elements of Nitrogen. Phosphorus, and Potassium, but with the exception of the few organic fertilizers, they in no wise directly return the humus and organic acids produced by decaylne organic matter.

Information concerning the chemical composition of plants and natural begotation is very limited as compared with the total number of plants which have been studied, and the major portion of the investigations which have been conducted have been confined to weeds and grasses which grow in competition with cultivated crops.

Ince (23) determined the anount of nitrogen in 13 comon weeds whlch occurred in the cultivated fields of North Dakota and found that 24 out of 
27 weeds which were analyzed contained a larger andunt of nitrogen and phosphorus than wheat, oats, barley, or flax. The average nitrogen content of these reeds was 2.53 percent and the phosphorus content was 0.29 percent on the dry matter basis.

Snyder (57) analyzed 15 different reeds for their n1trogen and found that on the average they contalned 3.01 percent of this element. There wis found more proteln in the dry matter of these weeds than in either alfalfa or clover. Portulaca contalned the largest amount which was 4.40 percent. Because of the large amount of mineral matter which they contain, he suggests the weeds are not dellcate feeders, and when they are burned or removed from the land a large amount of the nitrogen and mineral matter is lost.

Pickell (40) determined the protein content in 9 Fiorlda reeds and found that most of the plants were relatively low in nitrogen as compared with the results of the two previous investipators, although Portu1aca olearlacea contained 4.05 percent nitrogen, which $1 \mathrm{~s}$ similar to the results secured by snyder.

Campbell (5) studied the nitrogen content in the tops of 11 winter annuals which were collected in the fall and again in the spring. He found that the spring growth contained on the average 3.53 percent nitrogen as compared to 2.63 percent which occurred in the leaves and stems which grem in the fall. A comparison of the nitrogen content of nine annual plants at different stages of growth indicated that a rapld decrease in the nitrogen content occurs between the blooming period and maturity. Six weeds growling in rye contafned about the same amount of nitrogen as the rye plants when karvested at different periods during 
the growng season. The roots of certain reeds contained maller amounts of nitrogen than the leaves and the stems were usually higher in viant food elements than the roots.

Milisnaugh (33) Enalyzed 49 different plants for total nitrogen. phoshorus, and notash and his remite indicate that the composition of weeds and grasses are very similar to that of the cultivated crops although a marked variation occurs in cortain spectes.

Cooper (9) foumd that the nitrogen phosphorus and calciun content of Poa pratense. Danthonia solcata, and Andropogon virginicus were all low when these nlants were in full blonw. Ckulckshank (10) and others have shorn that the nitrogen ard nhosphorus content of grasses decrease as tho season advances and that young grass is higher in nitrogen.

Stutzer and seldle* (58) analyzed seren imortant reeds for nttrogen, phosphorus, potassiun, sodium, and calcium. These weeds contalned larger amounts of nlant food than ordinary fleld crops, and in soins instances plants which contrined large amounts of calclum pere low in cotassium. Kling (2) made a survey of the German literature on the chemical composition of weeds and reported the analysis of 6 common weeds, all of which were very high in plant food. The average nitrogen content wos $3.6 !$ percent, phosphorus 0.52 percent, calcium 2.35 percent, and potassium 6.20 percent. These analyses were mash higher than those gecured by stutzer and seldier on the same kind of plants.

Harper (16) and others made a study of the nitrogen, phosphorus and calcium content of comon weede and native grasses frowing in Oklahoma. Two hundred and twenty nine composite samples rere collected and analyzed. This collection included 50 different species of olants. Feecs were higher in nitrogen, phosphorus and calcium than the grasses, and plante growing 
on good soll were higher in nitrogen than similar plants growing on poor soil. Toung plants were higher in mineral nutrients and nitrogen then older plunts. The stens were lower in nitrogen phosohorus and calElum than the leaves. Plants growing on the same soll were found to be different in mineral anolysis. This was explained on the difference in the feeding power of plants.

Harper and $\mathrm{D}$ anfel (17) made an analysis of the vegetation in ponds and lakes near st111water, oklahome. for nitrogen, phosphorus, and calciun. The nitrogen content was higher than that which 1 s found in weed and grasses. This was also true for the phosphoru content. All samples of Elodea canadensis were high in calcium while those of Typhs lat1folla were very low.

Greenhill and Page (14) analyzed pasture grasses zepresenting from flve weeks growth under Intensive systems of grass land management and found that the lime cnntent varied during the season, but there rere no indications of a seasonal trend. The average seasonal content was practically the same in all cases. The phosphorlc acld content showed a def1nite seasonal trend, decreasing during drought or the early sumer flush period and increasing again after the flush period. There was a significant correlation between the phosphoric acid and the nitrogen content. Variations in the total akh and silica contents were less definite during the season. Good quality untreated samples contained less total ash and phosphorus than the ingensive pastures, but similar amounts of 11 me and s111ca.

Mitchell ( $33 a$ ) found that phosphorus content of plants was increased by fertilization. Applications of lime atded in the assinilation of phosphorus by legume plants. Three hundred pounds of ammonium sulfate 
per acre increased the nitrogen content of rye and clover from 28 to 40 percent. Copper, zinc, and manganese showed no effects. Mascheupt (29) studied the effect of the different kinds of soll and fertilizer, soilum nitrate, potassium nitrate, and ammonium sulfate on the content of nitrogen and ash in barley, rye, beets, oats, and notatoes. The influence of the kind of soll was greater wth straw, beet and notato leaves than with grain or roots and was greatest in silica content of stran. The average sillca content of straw from clav soll was five times that of strav from heather solls. The kind of fertilizer had no marked influence uron the nitrogen content and ash of crops on these solis. The solls were heather, moor, swamp, loan, and clay.

Hepner (80) studied the chemical composition of 63 samoles of Wroming grasses. Fushes ant sedges from different altitudes rangtng from 6.900 feet to 10,000 feet. The avergge nitrogen content of all crops grom below 8.000 feet was 1.385 percent. A convlote analysis of 25 soils Filed to roveal any correlation betwen the nitrogen contient of the plants and any of the soll constituents. He thinks that other factors play a much more imcortant role than does the soll in causing increased Etorage of nitrogen by high altitude plants. Foagland $(20 \mathrm{a})$ is of the opinion that the intake of mineral nutrients may be influenced by several fectors such ss the ratio of antons to anions, cetions to cations, and anfons to cations: the nower of the soll to sunly mineral elements and the conditions surrounding the ton together with conditions favorable to the exnansion of the root system.

Cruickshank (10) analyzed semples of some different apecies of plent: collected from the same ficld and found that there was a natural difference in the rineral composition of different snecies, the most 
outstanding of which was between the legumes and the grasses. Iegumes tend to be richer than the grasses in minerals, Expocially in calcium content. The erasses are relatively richer in phosphorus than the legumes. A ratio of calcium to phosphorus was found to be 1 to 0.3 in alfalfa. 1 to 3.8 in timothy, 1 to 0.45 in clover, as compared to 1 to 1.6 in rye grass.

Orr (39) renorted four main conditions under thich the mineral content of the plant eay vary, namely: the species of the plant: the stage of gromth: climatic conditions: and the nature of the soll. A rich soll favors the spread of those species phich are naturally rich in minerals and also tends to enrich the individual plant whatever its species.

Iljin (22) studies the composition of plants under different conditions. He renorted that the amount of one or the other elenents in plants depends on the composition of the soll or unon the ability of the plant to accumulate some certain proferred ion. The influence of the soil on the accumalation of notassium. is very weak. With most plants the more calcium presont in the soll the more they take ur. especially is lime taicen uo on Ilmestone solls. The drier the climate and the stronger the tranguiration of the plants the more calcium is found in soecles living on limestone sils. Many species regulate their calcium content by accunnl-ting a constant amount on many different types of soils. On one and tine sane soil the calcium intake of different plants may be different. 


\section{SURMARY FRON IITERATURE REVIET}

Material of a high cellulose content or a wide carbon nitrogen ratio when added to the soil are attacked mostly by soil fungi vith 11ttle or no mineral nitrogen 11berated, and a depression of soll nitrates.

Pentosans are relatively easily decomnosed, but their resistance to decomposition varies $\mathbb{N}$ th the source.

Plant materials that have a high water soluble nitrogen fraction are retarded in their rate of decompostion by the removal of this fraction, indicating that decomposition may be controlled by the amount of water soluble nitrogen present. If the total nitrogen content is less than 1.7 percent, decay vill be marked by a reducison in the nitrate content of the soll.

Isignin is the greatest contributor to soil hums of the various plant products. It is of a higher carbon content. and is attacked but slightly by soil bacteria and fungl.

Drying of plant tissue or green manures retards decomposition probably due to a retarding effect on the entrance of soil organisms and a change in the solubility of the products.

Carbon-iloxide evolution indicate that an alkaline soil provides a larger number of soll organisms than an acid soll, and decomposition is more ranid. Blological activities are not wholly inde pendent of soil reaction.

The mineral content of plants may vary according to thes species of plant: stage of growth: climatic condition: and the nature of the soll. Weeds in general are higher than the grasses in nitrogen, phosphorus, calcium, and potassium. 


\section{METHOD}

The olant parts used were finely ground and incorporated into sand and into soll in one gallon stone fars. The experiment was carried on over a period of 8 meeks and in a. fer instances to 9 reeks. Diring this perlod an analysis was made to determine the rate of decomoosition as indicated by the amount of amonia and nitrate nitrogen fomed.

The soll used was a Yexrimac eandy loara from the experimorit

station farm. It was allowed to dry out considerably so as to be easily screened and pulverized. In the case of the sand, glass sand was secured from the Berkshire Sand Coupany and treated similar to the soll. In the Iime treatments-the equivalent of 2 tons per acre अas used.

A sufficlent amount of soll was welghed to provide $z$ pounds for each, pot used in the series. To $1 \mathrm{t}$ was added the required moncalclum phosphate and notassium sulfate which was constant throughout the investigation. After a thorough mixing 16 nounds wes welghed and into It was put the eround nlant tissue. The mixture was then divided oqually Into two pots.

Bach pot contalned 8 pounds of slightly wolst soll with a total nitrogen content of 0.143 percent, which was 5.19 grams of nitrogon par pot. The carbon content of this soll was 1.63 percent which was 59.15 grams of carbon cer pot. The total nitrogen content of the plant tissue was determined and equivalent quantities of nitrogen addod from onch source to make 0.41 gram. It was unfortunate that in this investigation equivalent quantities of carbon. $11 \mathrm{gnin}$. cellulose, etc. could not be adied, and at the same time have an equivalent quantity of nitrogen. This factor should be kept in mind in making deductions from this work. 
All materials mere collected in the fall or in their green stage and dried imrediately. Oat straw, rye straw, and corm stover were secured from farters north of the college. All others except cottenseed hulls. buckwhont hulls, sorghum and seaweed (Ascophylum nodosum) were secured locally, efther surolied by the department or collected locally. Only the above ground parts were used.

\section{PRETARATTON OF MATTERIALS}

The materials were prepared by firct passing them through an ensilage cutter, which cut then into lengthe from a fraction of an inch to 1 inch or longer. They were then dried in a steam heated air drier at to to $70^{\circ} \mathrm{C}$. After they were thoroughly aried they pere ground in a Ianse Brothers and mite burr wil whlch ground them into e coarse meal. They were then nut in a wiley mill and chopped until fine enough to pass a I milimeter sieve. This material was then mixed thoroughly and a composite sample taken for makine determinations. The sarnle was placed in

a Little Trojan Ball mill and pounded for a day or overnight which ground them to a very fine nowder, except in the case of the wonocotyledonous group which were very hard to powder. The material as taken from the W1ley mill ras used for incorporation in the soll.

The organic nitrogenous materials were incorporated in the soil, and the soil placed in 1 gajlon stone jars and moistened to about 20 to 25 percent molsture on the dry basis and allowed to set for one week. 


\section{DETERMINATONS}

Total nitrogen deterninations vere made by the method of Ranker (42), for making total nitrogeu detcrminations in plant tis sue.

Carbon was dotermined by combustion in a stream of oxygen. The carbon-dioxide was absorbed by ascarlte and weighed.

Pentosans werc deternined by the official rethods of The Assoclation of offlcial Agricultural Chemists (39a).

If gnins were determined by the method of Vehta (32) (alkal1 method) at 30 pounds preseure and the results multiplied by 3.743 as 26.72 percent of the 11 gnocellulose was resolved at this pressure.

Nitretee vere deternined colorimetrically by the use of phenoldIsulfonlc acid in an alkaline soiution (described in Bureau of Solls Bullotin $\$ 31,1906)(50)$.

Ammonia was determined by the method of Harper (15). 


\section{RISIITS}

The different plant waterials are listed on rage 27 . and a partial chemical analysis in Table I shoms the nitropen, carbon. pentose, and liguid content. The results are everages of duplicate determinations. In cases where the duplicate did not check favorably a third determination was rade end the two which most nearly checked were used for averages.

The accumulation of amonis and nitrate nitrogen in sand and in soll for treatrents 1 to 12 inciusive both with and without Iime are expressed as narts por cillion of nitrogen as I1 ated in Tables 3,5 . and 7. Alfalfa treaticent in sand and in soll was token as control. The corresnondine molstures for the amonia and nitrate determations are 11 sted in mables 4,6 and 8 .

Berley growth produced from similarly treated oots are listed In Table 20, in dry welghts and as percentage of control. The control was an equivalent quantity of nitrogen from nitrate of soda.

The accelerating or rotardine effect of the soll was not taken Into account, as this factor meg constant throughout the investigation for all treatnents. 
1. Sudan grass - Sorghum sorghum, var sudanense P.

2. Hilot Gerran - Setaria iselica L.

3. Oat straw - Avena sativa I.

4. Hye tren - Secale cereale I.

5. Timothy - Phleum pratense $L$.

6. Corr stcrer - Zoa ralze I.

7. Ped Clover - Trifolium pratense I.

8. Alfalfa - Modiceo sativa $x_{\text {. }}$

9. Buckwheat hulls - Fagopyrum esculentam Moench.

10. Coftonseed lulis - Gosaiplum vas. I.

11. Andropogon sorghum, var. I.

12. Tobacco (steia and Iesvas) Nicotiana tabacum I.

13. Fungi-Polyoorus betulinus Micheli.

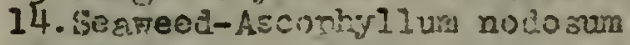

15. Club moss - Lucopodiun complanatum I.

16. Torseteils - Yqui setun aivense I.

17. Fern - Osmandae cinarmomea I.

18. Euttercup-Tammculus neris I.

19. Buakwheat - Fegopyrum esculentum Moerch.

20. Knotresil - Polygunum nviculare I.

21. Smartweed - Polygonum dersicaria L.

22. Pepner - . Mnsicirn annun l.

23. Potato top - Solanum tuberrosum L.

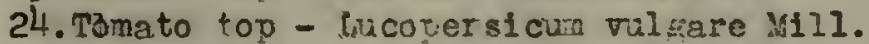

25. Artichoke - Helianthus tuberosus I.

26. Bidens - Btiens frundosa i.

27. Ragweed - Ambrosia artemesifolia I.

28. Xasthiun - Ianthiw canadense Mili.

29. Pursley -Portulaca oleariaceae I.

30. Amarisnth - Amoranthis retroflesus L.

31. Cabbage - Brassica ol eariaceao L.

32. Onlon - Allium cepa I.

33. Orchard grass - Dactylis glomerata I.

34. Lnmbs narter - chenopo3iua albun I.

35. Kentucky blue grass - Poa pratense I.

36. Turntu ton - Bresstea concestris $I$.

37. Canadian blue grass - Poa combressa I.

38. Sweet clover - lílilotus alta D.

39. Sedge - Carex luoulinus Muhl.

40. Sedge - Juncue effusus I.

41. Noss (Hairs Cap) - Polytrichum commune I.

42. Sedge - Carez stricta Lam.

43. Witch grass - Agropyron repens I (Beauv)

44. Gladiolus var.

45. Red Too - Agrost1s alba L. 
TABLE I - Results of partial chemical analyses of materials. Arranged in the order of decreasine nitrogen content. expressed in percentage of dry wt.

\begin{tabular}{|c|c|c|c|c|c|}
\hline Materials & Nitrogen & Carbon & $N-C \perp R$ & Pentosan & $\begin{array}{l}\text { Ilpnic } \\
\text { actd }\end{array}$ \\
\hline $\begin{array}{l}\text { Pursley } \\
\text { Amaranth } \\
\text { Cabbage } \\
\text { Tomato }\end{array}$ & $\begin{array}{l}4.48 \\
3.62 \\
3.58 \\
3.33\end{array}$ & $\begin{array}{l}35.98 \\
38.01 \\
41.07 \\
40.89\end{array}$ & $\begin{array}{l}1-8 \\
1-11 \\
1-12 \\
1-12\end{array}$ & $\begin{array}{l}8.90 \\
9.88 \\
5.10 \\
7.45\end{array}$ & $\begin{array}{r}9.36 \\
6.66 \\
4.08 \\
11.34\end{array}$ \\
\hline Tobacco & 2.99 & 38.17 & $1-13$ & $22.70 \mathrm{v}$ & 4.42 \\
\hline $\begin{array}{l}\text { Onion } \\
\text { Pepper }\end{array}$ & $\begin{array}{l}2.63 \\
2.56\end{array}$ & $\begin{array}{l}41.64 \\
38.25\end{array}$ & $\begin{array}{l}1-15 \\
1-15\end{array}$ & $\begin{array}{l}9.74 \\
8.32\end{array}$ & $\begin{array}{l}4.38 \\
4.23\end{array}$ \\
\hline $\begin{array}{l}\text { Bidens } \\
\text { Orchard grass }\end{array}$ & $\begin{array}{l}2.55 \\
2.54\end{array}$ & $\begin{array}{l}45.22 \\
47.17\end{array}$ & $\begin{array}{l}1-18 \\
1-19\end{array}$ & $\begin{array}{l}13.30 \\
12.14\end{array}$ & $\begin{array}{r}11.40 \\
7.67\end{array}$ \\
\hline Alfalfa & 2.43 & 47.84 & $1-20$ & 16.93 & 10.89 \\
\hline $\begin{array}{l}\text { Lambs quarter } \\
\text { Kentucky Blue Grass }\end{array}$ & $\begin{array}{l}2.43 \\
2.41\end{array}$ & 40.05 & $\begin{array}{l}1-17 \\
1-19\end{array}$ & $\begin{array}{r}8.62 \\
19.41\end{array}$ & $\begin{array}{l}4.45 \\
1.76\end{array}$ \\
\hline $\begin{array}{l}\text { Turnip top } \\
\text { Canadian Blue Grass }\end{array}$ & $\begin{array}{l}2.32 \\
2.29\end{array}$ & $\begin{array}{l}44.66 \\
45.84\end{array}$ & $\begin{array}{l}1-19 \\
1-20\end{array}$ & $\begin{array}{l}10.98 \\
13.70\end{array}$ & $\begin{aligned} 5.74 \\
14.15\end{aligned}$ \\
\hline Knot meed & 2.21 & 40.13 & $1-18$ & 8.12 & 10.18 \\
\hline $\begin{array}{l}\text { Buttercup } \\
\text { Ragweed }\end{array}$ & $\begin{array}{l}2.17 \\
2.15\end{array}$ & $\begin{array}{l}50.64 \\
45.16\end{array}$ & $\begin{array}{l}1-23 \\
1-21\end{array}$ & $\begin{array}{l}12.51 \\
14.82\end{array}$ & $\begin{array}{r}13.74 \\
2.06\end{array}$ \\
\hline Xanthium & 2.12 & $4 \longdiv { 1 . 2 8 }$ & $1-21$ & 9.17 & 6.44 \\
\hline Smartweed & 1.94 & 47.22 & $1-24$ & 9.27 & 16.58 \\
\hline Seaweed & 1.92 & 35.88 & $1-19$ & 10.17 & $9 \cdot 55$ \\
\hline $\begin{array}{l}\text { Red clover } \\
\text { Sweet clover }\end{array}$ & $\begin{array}{l}1.76 \\
1.67\end{array}$ & $\begin{array}{l}46.79 \\
47.55\end{array}$ & $\begin{array}{l}1-27 \\
1-29\end{array}$ & $\begin{array}{l}15.53 \\
10.59\end{array}$ & $\begin{array}{r}13.28 \\
5.61\end{array}$ \\
\hline Carex luoulinus & 1.62 & 50.69 & $1-31$ & $23 \cdot 32$ & $11 \cdot 34$ \\
\hline Millet German & 1.56 & 46.19 & $1-30$ & 26.45 & 14.84 \\
\hline Juncus effusus & 1.52 & 50.23 & $1-33$ & $25 \cdot 54$ & 30.24 \\
\hline $\begin{array}{l}\text { Buckwheat } \\
\text { Potato top }\end{array}$ & 1.50 & $\begin{array}{l}411.08 \\
35.75\end{array}$ & $\begin{array}{l}1-29 \\
1-25\end{array}$ & $\begin{array}{l}9.76 \\
8.31\end{array}$ & $\begin{array}{r}9.47 \\
10.22\end{array}$ \\
\hline Noss halrs cap & 1.42 & 43.47 & $1-27$ & 6.89 & 16.47 \\
\hline Carex stricta & 1.41 & 50.18 & $1-35$ & $25 \cdot 74$ & 21.26 \\
\hline Witch grass & 1.36 & 50.46 & $1-36$ & 16.96 & 15.08 \\
\hline Sudan Erass & 1.36 & 46.63 & $1-3^{4}$ & $22 \cdot 91$ & 13.96 \\
\hline Gladidlus & 1.21 & 48.02 & $1-40$ & 19.73 & 14.41 \\
\hline $\begin{array}{l}\text { Horsetalls } \\
\text { Fern }\end{array}$ & $\begin{array}{l}1.19 \\
1.13\end{array}$ & $\begin{array}{l}32.89 \\
48.71\end{array}$ & $\begin{array}{l}1-28 \\
1-43\end{array}$ & $\begin{array}{l}6.89 \\
7.56\end{array}$ & $\begin{array}{r}6.40 \\
12.76\end{array}$ \\
\hline Fungl & 1.09 & 47.48 & $1-44$ & & 19.24 \\
\hline Oat straw & 1.03 & 49.71 & $1-48$ & 26.90 & 18.53 \\
\hline $\begin{array}{l}\text { Corn stover } \\
\text { Timothy }\end{array}$ & $\begin{array}{l}1.02 \\
0.86\end{array}$ & $\begin{array}{l}45.94 \\
49.90\end{array}$ & $\begin{array}{l}1-45 \\
1-58\end{array}$ & $\begin{array}{l}27.17 \mathrm{~L} \\
18.70 \mathrm{~L}\end{array}$ & $\begin{array}{r}9.84 \\
13.96\end{array}$ \\
\hline Red top & 0.86 & 47.68 & $1-55$ & $21.32 v$ & 5.20 \\
\hline Club moss & 0.83 & 46.32 & $1-56$ & 8.82 & 4.19 \\
\hline $\begin{array}{l}\text { Articholre } \\
\text { Sorghum }\end{array}$ & $\begin{array}{l}0.67 \\
0.62\end{array}$ & $\begin{array}{l}45.87 \\
46.23\end{array}$ & $\begin{array}{l}1-68 \\
1-75\end{array}$ & $\begin{array}{l}11.85 \\
22.06\end{array}$ & $\begin{array}{r}3.97 \\
13.92\end{array}$ \\
\hline Cottonseed hulls & 0.57 & 47.18 & $1-83$ & 31.63 & 17.26 \\
\hline Rye straw & 0.53 & 47.20 & $1-89$ & $27 \cdot 36$ & 15.16 \\
\hline Bucicwheat hulls & 0.52 & 49.76 & $1-96$ & 24.33 & 20.62 \\
\hline
\end{tabular}


TABLE II - Grams of materials added to maintain 41 gan. nitrogen arranged in the order of increasing quantities. The calculated additional amounts of carbon in gram in the paraliel column.

Organic source

Pursley

Amaranth

Oabbage

Tomato

Tobacco

Feppe:

Bidens

Lambs quarter

Alfelfa

Onion

Orchord grass

Kontucky blue grass

Candian blue grass

Ragweed

Xanthium

Turnip top

Buttercup

Seaweed

Red clover

sweet cover

Millet

Carex Iupulinus

Buckwheat

Juncus effusus

Potato top

Moss halrs cap

Sudan grass

Carex stricta

Mitch grass

Horsetalls

Gladiolus

Knotweed

Fungl

Corn stover

Ferm

Cat straw

Smartweed

Timothy

Red top

qlub moss

Arti choke

Sorghum

Cottonseed hull.

pye straw

Buckwheat hulls
Grams of material added per 8 \$ soll
Grams of carbon added.

10.7

12.1

13.2

13.7

14.9

17.6

17.7

17.8

18.2

18.5

18.6

19.0

19.8

20.9

21.0

21.8

23.4

23.5

25.2

27.2

28.4

28.5

30.2

30.2

30.3

31.1

32.0

32.1

32.9

36.7

38.5

40.8

41.8

42.6

42.6

45.5

48.1

49.3

53.5

54.2

66.9

73.3

80.9

81.5

84.1
4.0

4.6

$5 . \frac{7}{5}$

5.7

6.8

8.0

7.1

8.7

7.7

8.8

8.7

9.1

9.4

9.3

9.7

11.9

11.8

12.9

13.1

14.5

13.3

15.2

10.8

13.5

14.9

16.1

16.6

12.0

18.5

19.8

19.6

20.7

22.6

22.7

24.6

25.5

25.1

30.7

33.9

38.2

38.5

41.8

Soll intentipy of carbon and nitrogen present 
TABLE III - Parts per million of amnonia and nitrate
nitrogen produced in soll from the addition
of . Il of nitrogen from the plants listed.

Time in days

14

21

28

$\mathrm{p} \cdot \mathrm{p} \cdot \mathrm{m} \cdot$

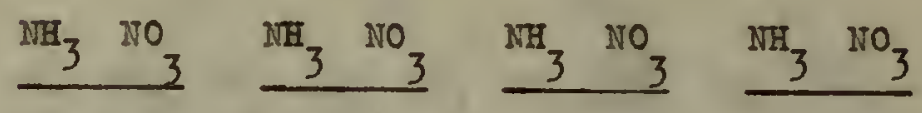

1. Sudan grass

2. German millot

3. Oat stran

4. Rye straw

5. Timothy

6. Corn stover

7. Red Clover

8. Alfalfa

9. Buckwheat hulls

10. Cottonseed hulls

11. Sorghum

12. Tobacco stems \& loaves

13. Fung1

14. Seaveed

15. Club moss

16. Horsetails

17. Fern

18. But tercup

19. Buckmheat

20. inotweed

21. Srartweed

22. Pepper

23. Potato tops

24. Tomato tops

25. Arti choke

26 . Bidens

27. Ragweed

28. Xanthium

29. Pursley

30. Amaranth

31. Cabbage

32. Oni on

33. Orchard grass

31. Lambs quarter

35. Kentucky blue grass 3

37. Canadian blue grass 1

38. Sweet clover

39. Carex Iupulinus

40. Juncus effusus

41. Woss (Hairs cap)

42. Carex stricta

43. \#1tch grass

44. Gladioli

45.Red top

$\overline{-}$

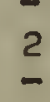

$\begin{array}{ccc}13 & 1 & 15 \\ 25 & 2 & 28 \\ - & 1 & - \\ - & - & - \\ - & 1 & - \\ 33 & 1 & 25\end{array}$

- - -

$-2 T$

$\begin{array}{lll}\overline{77} & \overline{1} & \overline{7}\end{array}$

$5 \frac{1}{4}$

2 -

$3=$

$3-$

3

45

352

148

1 -

$\begin{array}{ll}2 & 27 \\ 2 & 28\end{array}$

$-53$

695

435

3

337

4

13

34

94

$\begin{array}{ll}3 & 33 \\ 4 & 24\end{array}$

$5 \quad 27$

523

7

T

$T$

$\begin{array}{lll}T & 5 & - \\ T & 3 & 32\end{array}$

$\overline{32}$

2

$\begin{array}{cccc}1 & 30 & 1 & 22 \\ 1 & 64 & 1 & 48 \\ - & \mathrm{T} & 1 & \mathrm{~T}\end{array}$

2 - - -

- - $-T^{-}$

$\begin{array}{llll}2 & 51 & 2 & 82\end{array}$

- $118-115$

4 - - -

1 - - -

1 - - -

$\begin{array}{llll}3 & 236 & - & 137\end{array}$

$\begin{array}{llll}4 & 56 & 4 & 57\end{array}$

$\begin{array}{llll}3 & - & 5 & -\end{array}$

$2-4$

$\begin{array}{llll}2 & 9 & 4 & 14\end{array}$

51

$58 \quad 3 \quad 51$

$\begin{array}{lll}11 & 2 & 20 \\ 84 & 4 & 47\end{array}$

$\begin{array}{lll}61 & 2 & 70\end{array}$

$\begin{array}{llll}1 & 75 & 3 & 67\end{array}$

134145

$\begin{array}{llll}1 & 50 & 1 & 43\end{array}$

337360

$1 \quad 1013282$

$\begin{array}{llll}2 & 88 & 2 & 85\end{array}$

$\begin{array}{llll}2 & 78 & 3 & 76\end{array}$

$\begin{array}{llll}3 & 46 & 3 & 47\end{array}$

$2 \quad 12 \quad 2 \quad 20$

$\begin{array}{llll}2 & 75 & 6 & 100\end{array}$

$\begin{array}{llll}5 & 37 & 5 & 45\end{array}$

$\begin{array}{llll}1 & 22 & 5 & 28\end{array}$

$\begin{array}{llll}4 & 29 & 3 & 40\end{array}$

$\begin{array}{llll}4 & 34 & 2 & 45\end{array}$

$$
3
$$

31

31

$3=$ 
TABLE III (Comt.) - Ports per million of amonia and nitrate nitrogen preduced in 8011 from the eddition of .41 of nitropen from the plante 11 sted.

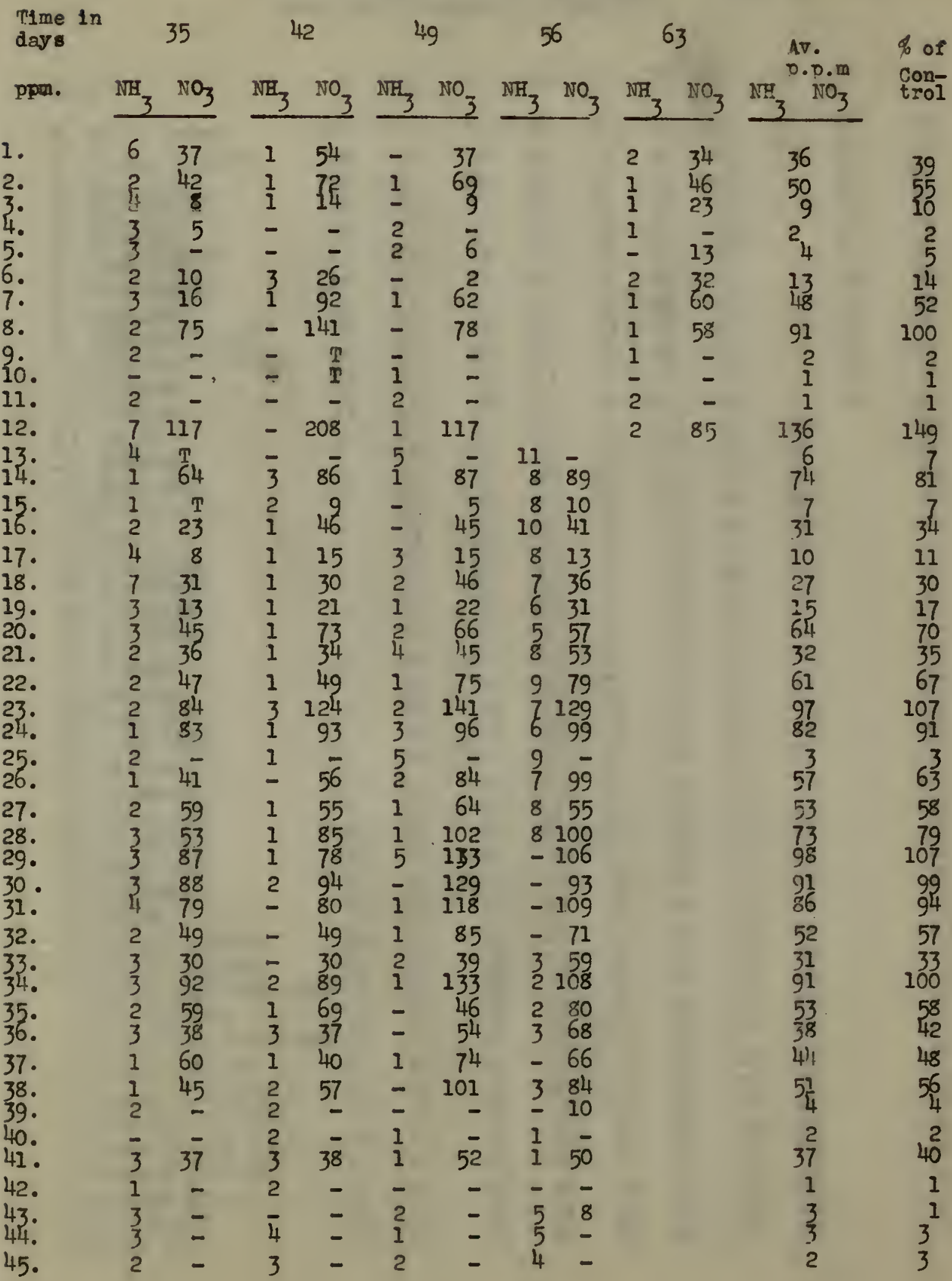




\section{TABLI IV - Percentage mol retre content of soll on which amonfa and nitrate aftrogen determinations wore made, as indicated in Table III.}

Days

1. Sudan grass

2. German millet

3. Oat straw

4. Rye straw

5. Timothy

6. Corn stover

7. Red clover

8. Alfalfa

9. Buclswheat hulls

10. Cottonseed hulls

11. Sor ghum

12. Tobacco

13. Tungt

14. Seaveed

15. club moss

16. Eorsetails

17. Fern

18. But tercup

19. Buckwheat

20. Knotweed

21. Smartweed

22.Pepper

23. Patato

24. Tomato

25. Art 1 choke

26. B1dens

27. Ragweed

28. Xanthium

29.Pursley

30. Amaranth

31. Cabbage

32. Onion

33. Orchard grass

34. Lambs quarter

35. Kentucky blue grass 23

36. Turnin top

37. Canadian blue grams 21

38. Sweet clover

39. Carex lupulanus

40. Juncus ef rusus

41. Noss (Hairs can)

42. Carex stricta

43. Witch grass

44. Gladiol1

45. Red top $\begin{array}{llllllllll}7 & 14 & 21 & 28 & 35 & 42 & 49 & 56 & 63 & \text { Av. }\end{array}$

$\begin{array}{lllllll}22 & 21 & 23 & 24 & 24 & 21 & 20\end{array}$

$\begin{array}{lllllll}18 & 19 & 22 & 22 & 20 & 18 & 18\end{array}$

$\begin{array}{lllllll}18 & 27 & 28 & 25 & 22 & 24 & 22\end{array}$

$\begin{array}{lllllll}19 & 25 & 27 & 22 & 20 & 21 & 21\end{array}$

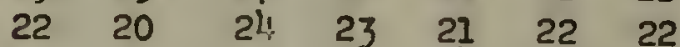

$25 \quad 27$

29

$25 \quad 24$

$23 \quad 22$

$20 \quad 21$

$25 \quad 23$

1721

2022

3133

1924

2124

1723

20

21

19

19

25

22

21

$20 \quad 19$

24

22

20

22

20

$\begin{array}{lll}33 & 28 & 27\end{array}$

$23 \quad 22 \quad 28$

$\begin{array}{lll}23 & 25 & 25\end{array}$

18

17

17

24

27

30

27

17

$25 \quad 30$

23

21

22

21

$20 \quad 26$

$19 \quad 24$

1924

17

27

24

23

22

17

$22 \quad 26$

15
21

21

17

17

18

17

20

24

25

1716

21

23
18

22

22

18

$25 \quad 24$

$22 \quad 20$

21

17

$17 \quad 16$

15

17

17

20

21

19

23

23

31

20

24

28

24

20

22

22

21

23

27

23

$25 \quad 28$

25

21

22

23

25

25

28

25

27

21

$\begin{array}{lll}27 & 27 & 20\end{array}$

$\begin{array}{lll}27 & 33 & 21\end{array}$

1921

18 21

$19 \quad 22$

1922

$27 \quad 24$

$\begin{array}{ll}27 & 24 \\ 26 & 24\end{array}$

$29 \quad 31$

21

$27 \quad 24$

28

28

22

24

22

29

23

21

25

27
27

2519

$27 \quad 24$

$25 \quad 22$

$24 \quad 22$

$25 \quad 24$

$22 \quad 20$

$22 \quad 22$

$23 \quad 22$

2321

$25 \quad 29$

2122

31

34

28

21

24

25

17

21

21

30

25

27

18

17

19

20

24

25

18

21

20

21

22

23

23

22

20

21

22

20

24
28

24

19

29

22

23

23

18

21

19

24

20

24

19

17

20

20

22

23

21

23

24

25

24

24

24

23
24

24

24

23
$21 \quad 24$

23
26

20
22

25
23 
TABLE V - Parts per million of grmonia and nitrate nitrogen produced in soll from the addtion of .il Exams of nitrogen from the plants listed pluse the equivalent of 2 tons of limestone per acre.

Days
7
14
21
28
$\mathrm{III}_{3} \mathrm{NO}_{3}$
$\mathrm{NH}_{3} \mathrm{NO}_{3} \quad \mathrm{NH}_{3} \quad \mathrm{NO}_{3}$
$\mathrm{NE}_{3} \mathrm{NO}_{3}$

1. Sudan prass

2. German millet

3. Oat strat

$\begin{array}{lr}2 & - \\ 1 & 9 \\ 2 & 9 \\ 2 & T \\ 2 & - \\ 2 & - \\ 3 & - \\ 2 & 54\end{array}$

क

4

$\begin{array}{rrr}14 & 5 & 5 \\ 15 & 6 & 30 \\ 16 & 2 & - \\ - & 6 & - \\ - & 3 & - \\ 97 & 5 & 18 \\ - & 6 & -\end{array}$

9. Buckwheat hulls 2

10. Cottonseed

5. Timothy

6. Gorn stover

7. Red clover

8. Alfalfa hulls 1

11. Sorginuia

12. Tobacco

13. Trung 1

14. Jeareed

1
1
1
4
4

15. Clut moss

16. Horsetalls

17. Sern

18. Buttercup

19. Buckwheat

20. Knotweed

21. Smartweed

22. Pepner

23. Putato tops 24. Tomato tops

$5 \overline{2}$

$2 \quad \mathrm{~T}$

$1 \quad T$

-

$1 \quad T$

-

110

$-\quad-$

- -

25. Art 1 choke

26. Bidens

27. Ragneed

28. Xanthium

$\begin{array}{ll}5 & 28 \\ 3 & 28\end{array}$

$\frac{1}{3}=$

5

$\begin{array}{rrrr}1 & - & 7 & - \\ 1 & 80 & 7 & 81 \\ 6 & - & 6 & - \\ 25 & 23 & 4 & 40\end{array}$

$2 \quad 10 \quad 2 \quad T$

$\begin{array}{llll}4 & 9 & 3 & \end{array}$

$2 \mathrm{~T}$

$3-$

116

3 T

$\begin{array}{llll}4 & 1 & 2 & 24\end{array}$

$\begin{array}{ll}6 & - \\ - & 61 \\ 3 & T \\ 3 & T \\ 1 & T \\ 4 & T \\ 3 & - \\ 2 & 48 \\ 2 & 5 \\ 3 & 37 \\ 1 & 37 \\ 1 & 82 \\ 1 & 59 \\ 1 & 39 \\ 2 & 37 \\ 2 & 57\end{array}$ 
TABLE V (cont.) - Pasts por allion of amonla end nitrate nitrogon produced in soll from the addition of .'I proms of nitropen fron the rlants listed plus the equivalent of 2 tons of 11 iestone por sere.

Daves 35 $14 \quad 49 \quad 56 \quad-63 \quad$ Av. control

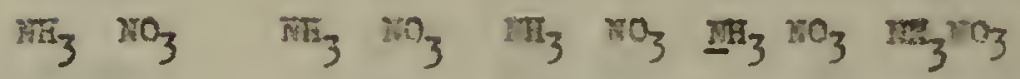

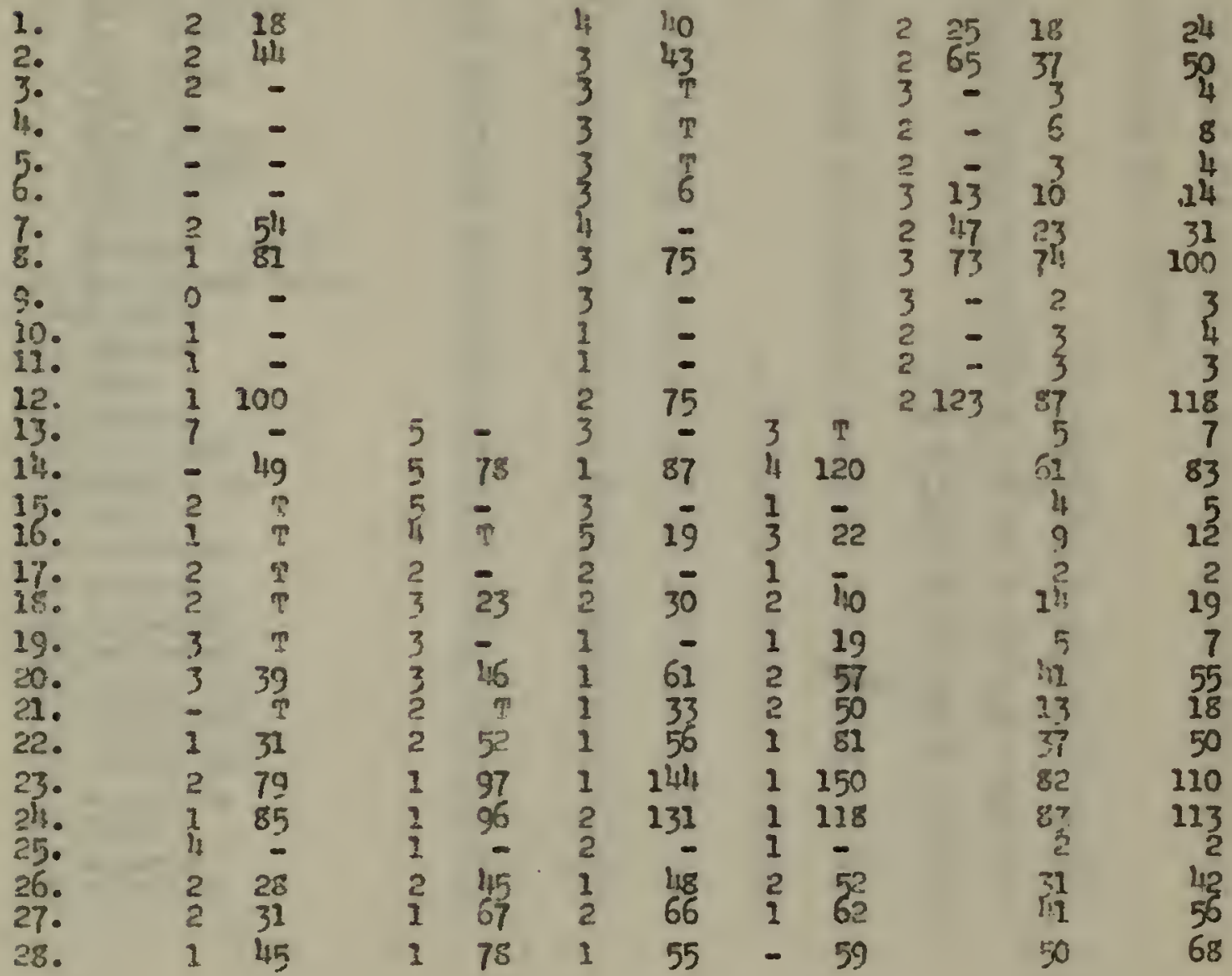


TABLE VI - Percentage molsture content of soll plus lime on which ammonia and nitrate nitrogen determinations were made, as indicated in Table $\mathrm{V}$.

Days

1. Sudan grass

2. Berman Millet

3. Oat straw

4. Rye straw

5. Timothy

6. Corn stover

7. Red clover

8. Alfalfa

9. Buckwhert holls

10. Cottonseed hulls

11. So rghum

12. Tobacco

13. Iung1

14. Searreed

15. Club moss

16. Horsetalls

17. Fern

18. Buttercup

19. Buckwheat

20. Knotweed

31. Smartweed

22. Pepper top

23. Potato top

24. Tomato top

25. Art1 choke

26. Bidens

27. Ragwe ed

28. Xan thium $\begin{array}{llllllllll}7 & 14 & 21 & 28 & 35 & 42 & 49 & 56 & 63 & \text { Av. }\end{array}$

$\begin{array}{lll}34 & 23 & 25 \\ 33 & 25 & 26 \\ 26 & 17 & 25\end{array}$

$29 \quad 23 \quad 28$

$\begin{array}{lll}26 & 24 & 27 \\ 33 & 28 & 32\end{array}$

$\begin{array}{lll}32 & 26 & 29 \\ 25 & 20 & 24\end{array}$

$29 \quad 23 \quad 25$

$21 \quad 20 \quad 22$

$\begin{array}{lll}31 & 30 & 33\end{array}$

$\begin{array}{lll}29 & 19 & 25\end{array}$

23

26

23

27

23
24

24

26

27

22

27

25

$\begin{array}{ll}22 & 27 \\ 23 & 25\end{array}$

25
22 $\begin{array}{llll}18 & 19 & 16 & 22 \\ 17 & 18 & 22 & 23 \\ 19 & 21 & 24 & 22\end{array}$

$\begin{array}{llll}19 & 21 & 26 & 24\end{array}$

$19 \quad 17 \quad 24 \quad 22$

$\begin{array}{llll}19 & 30 & 27\end{array}$

$\begin{array}{llll}19 & 15 & 24 & 24\end{array}$

$2316 \quad 1720$

$\begin{array}{llll}18 & 16 & 19 & 21\end{array}$

$\begin{array}{llll}24 & 23 & 25 & 27\end{array}$

$\begin{array}{llll}18 & 17 & 17 & 20\end{array}$

$\begin{array}{lllllll}31 & 31 & 29 & 28 & 29 & & 28\end{array}$

$\begin{array}{llllll}23 & 31 & 26 & 24 & 25 & 25\end{array}$

$\begin{array}{lllll}28 & 34 & 29 & 26 & 26\end{array}$

$\begin{array}{lllll}23 & 26 & 23 & 24 & 26\end{array}$

2936

$25 \quad 33$

$\begin{array}{lll}29 & 28 & 32 \\ 26 & 21 & 24\end{array}$

$\begin{array}{lll}28 & 27 & 28\end{array}$

$\begin{array}{lllll}25 & 24 & 17 & 22 & 22 \\ 32 & 31 & 24 & 29 & 27\end{array}$

$22 \quad 1922$

$\begin{array}{lll}24 & 20 & 31\end{array}$

$\begin{array}{lll}22 & 17 & 21\end{array}$

$\begin{array}{lll}33 & 25 & 27 \\ 19 & 17 & 18\end{array}$

$20 \quad 22 \quad 26$

$\begin{array}{lll}27 & 18 & 19\end{array}$ $\begin{array}{llll}18 & 19 & 21 & 20\end{array}$ 


\section{TABLE VII - Annonia and nitrate nitrogen produced in sand with and without lime from the addition of . 1 grams of nitrogen from the plants 11sted.}

Sand

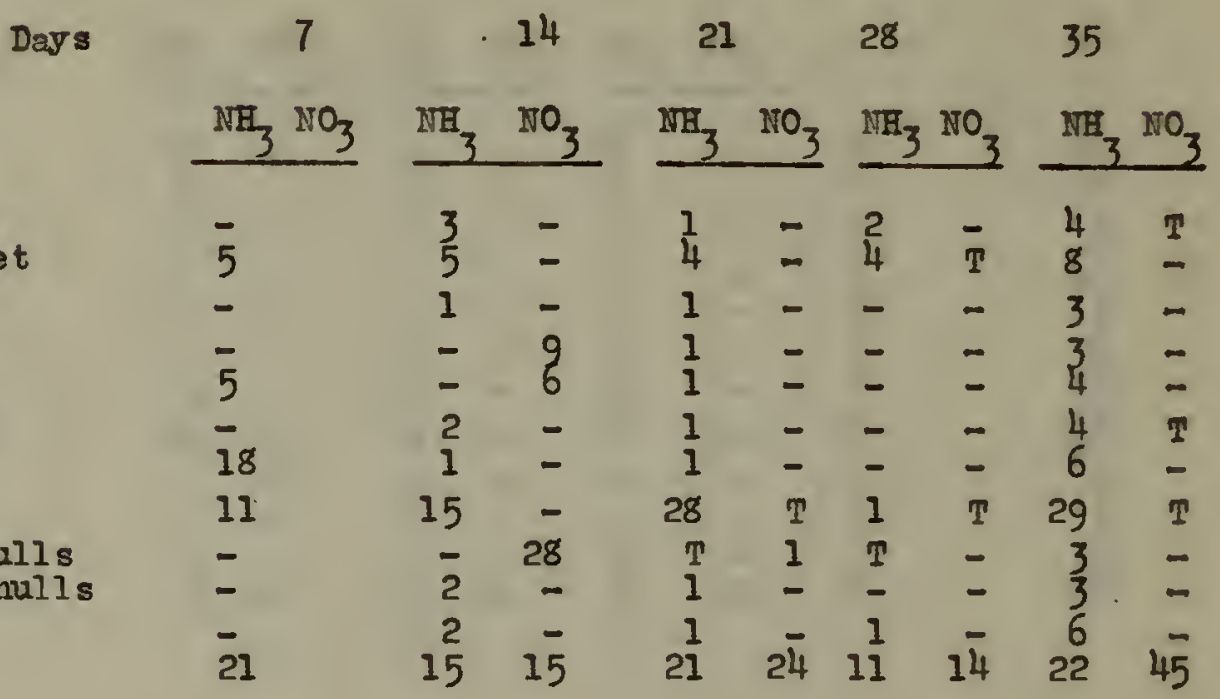

Sand-IIme Treatment

Days

19

35

49

1. Sudan grass

2. German Millet

3. Oat straw

4. Rye straw

5. Timothy

6. Corn stover

7. Red clover

8. Alfalfa

9. Buckwheat hulls

10. Cottonseed hulls

11. Sorghum

12. Tobacco
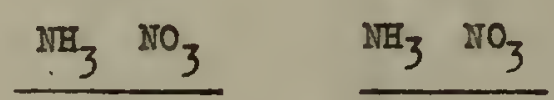

$\mathrm{NH}_{3} \mathrm{NO}_{3}$

1. Sudan grass

2. Gernan Millet

3. Oat straw

4. Rye strar

5. TImothy

6. Corn stover

7. Red clover

8. Alfalfa

9. Buckwheat hulls 10. Cottonseed hulls 11. Sorghum

$6=$
$1=$
$3=$
$2=$
$1=$
$2=$
$2=$
$6=$
$1=$
$2=$
$3=$

12. Tobacco 
TABLE VII (Cont.) - Armonia and nitrate nitrogen produced
in sand with and without lime from the addition
of .41 grams of nitrogen from the plants listed.

Sand

\begin{tabular}{|c|c|c|c|c|c|c|c|c|}
\hline \multirow{2}{*}{$\begin{array}{l}\text { Sand } \\
\text { Days }\end{array}$} & \multicolumn{2}{|c|}{42} & \multicolumn{2}{|c|}{49} & \multicolumn{2}{|c|}{63} & \multirow[t]{2}{*}{ Av. } & \multirow[t]{2}{*}{$\begin{array}{l}\text { क of } \\
\text { Control }\end{array}$} \\
\hline & $\mathrm{NH}_{3}$ & $\mathrm{NO}_{3}$ & $\mathrm{NH}_{3}$ & $\mathrm{NO}_{3}$ & $\mathrm{NH}_{3}$ & $\mathrm{NO}_{3}$ & & \\
\hline $\begin{array}{l}1 . \\
2 .\end{array}$ & $\begin{array}{l}4 \\
8\end{array}$ & $\overline{-}$ & $\begin{array}{l}6 \\
6\end{array}$ & I & 5 & - & $\begin{array}{l}4 \\
6\end{array}$ & $\begin{array}{l}16 \\
25\end{array}$ \\
\hline 3. & 2 & - & - & - & 1 & - & 2 & 7 \\
\hline 4. & 1 & - & - & - & 2 & - & 3 & 14 \\
\hline 5. & 1 & - & $\overline{5}$ & - & 1 & - & 3 & 13 \\
\hline 6. & - & - & 1 & - & 1 & - & 1 & 6 \\
\hline 7. & 8 & - & 2 & - & 9 & - & 7 & 29 \\
\hline 8. & 29 & 6 & 23 & - & 24 & 18 & 23 & 100 \\
\hline 9. & - & - & 1 & - & 2 & - & 1 & 6 \\
\hline 10. & - & - & - & - & - & - & 2 & 7 \\
\hline $\begin{array}{l}11 . \\
12 .\end{array}$ & 9 & $\overline{3}$ & $\begin{array}{r}2 \\
12\end{array}$ & $2 \overline{8}$ & $\begin{array}{l}2 \\
5\end{array}$ & $\overrightarrow{30}$ & $3 \frac{3}{8}$ & 14 \\
\hline
\end{tabular}

Sand-Iime Treatment

Days

63

1.

2.

3.

5.

7.

8.

9.

10.

11.

12.

$\begin{array}{rrrr}2 & - & 4 & 74 \\ 3 & - & 4 & 77 \\ 1 & - & 3 & 58 \\ 1 & = & 29 \\ 2 & - & 1 & 31 \\ - & - & 2 & 52 \\ 2 & - & 5 & 100 \\ 1 & - & 1 & 27 \\ 0 & - & 1 & 22 \\ 1 & - & 1 & 23 \\ 2 & - & 2 & 37\end{array}$




\section{TABBLE VIII - Pescentsge molsture contont of sand Fith and 1 thout 12 on which ramonta end nitrate nitrocen detezsinations vere ande in Table VII. \\ Sand}

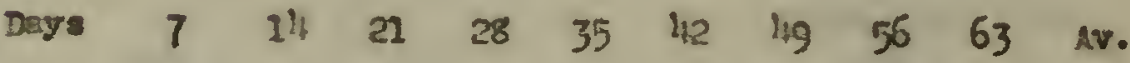

1. Sudอม Exnยs

2. Gerran millet

3. Dat traw

4. 1ye stras

5. F1rotho

6. com stove:

7. Ther ciover

8. Alfalfa

9. Incle-moat mils 10. Cottonseed hull

11. Sorgines

12. 10 obseco $\begin{array}{lllllll}5 & 10 & 9 & 9 & 10 & 8 & 7\end{array}$

$\begin{array}{lllllll}5 & 11 & 11 & 10 & 7 & 5 & 7\end{array}$

$\begin{array}{lllllll}8 & 11 & 16 & 11 & 12 & 7 & 11 \\ 8 & 8 & 12 & 11 & 9 & 7 & 8\end{array}$

$8 \quad 19$

$10 \quad 10 \quad 10$

510

99 il $11 \quad 8 \quad 6 \quad 8$

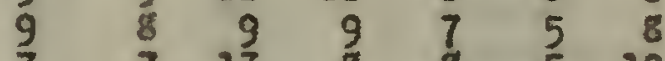

\&

13

11!

12

9
9
8
9

18

11.
7
8
9

16

8 . 55
119

118

141.0

2511

$10 \quad 10$

1210

910

108

1110

2215

108

Snre and Lime

1. Sutan Brass

2. Corran millot

3! Oat traw

4. Tye straw

5. Timothy

6. Corn stove:

7. Rod clover

8. Mralia

9. Buckwheat bulls

10. Cottonseed buils

11. So: ghum

12. Tobreco

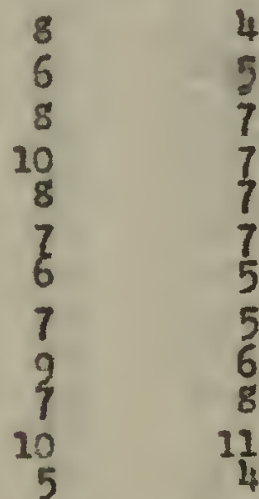

8
6
8
9
9
7
5
5
6
13
11

128

97

129

$18 \quad 11$

1510

$\begin{array}{cc}17 & 10 \\ 7 & 6\end{array}$

76

118

1210

$\begin{array}{cc}14 & 12 \\ 10 & 6\end{array}$ 
TABLE IX - A classifleation based on arerage p.p.M. of amonta and nitrate nitrogen produced po: weak, al 60 comparative waount: of arovonia and nitrato calculated in ternss of D.p.ta. utaing the emount of these furras of nitrogen evolved Pron control as 100. Included are Groups of th 1 ino and whout $11 \mathrm{me}$.

So11

1. "obaceo

2. pursley

3. Fotsto top

4. Mralfa

5. Lamb cuarter

6. Naranth

7. Cubbage

8. Tomento top

9. Sesweed

10. Xanthiun

11. rnotreed

12. Porner

13. B1dens

1i. Kentucles blue grase

15. Thepreed

16. Ontor

17. Sweet clover

18. nezang millet

19. Red clover

20. Csinda blue

22. Tumis top

22." "03s hatre cap

23. Sudan Exaes

24. Soustweed

25. Torsetalis

26. Orchar grass

27. 3ut to =cus

28. Nuclowhat

29. horg atder

30. 7 enz

31. Dat straw

32. Tlub noss

33. กun 1

34. Timothy

35. Carex trieta

36. 'tch grese

37. Art I cholce

35.01 adiolus

39. Red tap

40. Juncus ex โxurus

11. Fue strav

42. Dudewhent hull

13. Carex stricta

4i. . corestuses

45. Sottonsed hulls aิ.

p.p.s.

$\mathrm{WH}_{3} \mathrm{NO}_{3}$

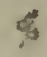

349

107

97

92

91

91

86

82

74

73

64

61

57

53

53

52

50

it

44

38

37

36

32

31

30

27

15

13

10

9

7

4

4

3

3

3

2

2

2

1

120

100

100

34

?1

ह1

Soll and Lime

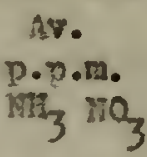

1. Tobseco

87

2. Fonato top

3. Fotato top

83

82

4. Alralfa

5. seaweed

74

6. ranthtum

61

50

7. กagmend

8. Fnotweed

41

9. Pepperar

10. (Nerman millet

11. B1 dens

1:2

37

12. Ned clover

13. Sudar eress

14. Buttercup

15. Smartweed

31

23

18

14

16. nom stover

13

57 17. Hormetalls

18. Jye stran

12

19. Pucknhbat

20. Pung1

21. C1ub mass

22. Ilsothy

23. nat stran

2h. Cot tonseed

25. Sorginuara

ma?

?

6.

27. Eerm

28. Axt1 cholce

118

113

116

100

83

68

56

55

50

50

42

31

24.

19

18.

14

12
8

7

5
4
4

4 


\section{TABTE IX -(Cont.) A classification bazed on average p.p.re. of ancinla and nitrate nitrogen produced per reek, also comparative amounts of anmoria and nitrate calculated in terms of o.p.m. using the anount of the se fozms of nitrogen evolved from control as 100 . Included are groups $\mathrm{Flth}$ lime and withaut lime.}

Sand

$\mathrm{Av}$.
$\mathrm{NB}$
$\mathrm{NB}_{3} \mathrm{NO}_{3}$

1. Mrobacco

2. Alfalfa

3. Red clover

4. German millet

5. sudan grass

6. Rye straw

7. Sorghum

8. Timothy

9. Cottonseed hulls

10.0at straw

11. Buckwheat hulls

12. Corn stover

Av.

37.36

22.80

6.50

5.76

3.56

3.22

3.08

2. 99

1.51

1.50

1.33

7.64 sand and Iime

\%

Av.

p.p.m.

$\mathrm{NE}_{3} \mathrm{NO}_{3}$

$\%$

\begin{tabular}{ll}
$4.56 \quad 100.00$ \\
\hline
\end{tabular}

1. Alfalfa

2.German millet

76.54

3. Sudan grass

3.49

73.90

28.51

4. Dat straw

58.33

15.61

5. Red clover

51.97

6. Tobacco

36.84

7. Timothy

30.48

13.51

3. Rye straw

$26.5 \frac{1}{2}$

6.75

3. Buckwheat bulls

1.30

2.37

1.68

10. Sorghum

1.11

24.34

6.01

11. Cottonseed huIls 1.01

22.15

5.83

12. Corn stover

1.00

21.93

33.45

2.10

45.96 
TABIE X - Dry welght in grams of barley plants grom in soll and in sand with and without 1 ime to which had been adsed quantities of plant tigsuo in proportions to furnl sh equal quantities of nitrogen.

So11

1. Sudan grass

2. German rillet

3. Oat straw

4. Rye straw

5. Timothy

6. Corn stover

7. Red clover

8. Alfelfa

9. Buckmbeat hulls

10. Cottonseed hulls

11. Sor ghum

12. "obacco

1.3. Tunef

14. Seaweed

15. $\mathrm{clab}$ rooss

16. Forsetails

17. Tern

18. Buttercup

19. Buckwheat

20. Knotwsed

21. Snartweed

22. Pepper

23. Potato top

24. Tomato top

25. Art1 choke

26. Bidens

27. Ragiveed

28. Xanthium

29. Pursley

30. Amaranth

31. Caibage

32. Onion

33. Orchard grass

34. Larnbs quarter

35. Kentucky Blue grass

36. Turnip top

37. Canadian blue grass

38. Sweot clover

39. Barex "I upül'tisus

40. Juncus ef fusus

41. Hoss (Ha1rs cap)

42. Carex stricta

43. W1 tch gass

4. Glad1olus

45. Red top

\section{Av. Ary क of wt.in $g$ control}

2.56
4.69
1.51
1.44
2.13
1.36
3.38
9.01
1.48
1.93
1.30
12.37
0.32

0.62

5.99

1.73

3.03

1.37

3.05

1.52

5.69

2.86

5.02

6.13

6.45

0.76

4.85

5.31

5.77

8.77

9.38

9.28

7.61

6.10

5.26

7.11

6.68

8.58

6.23

3.70

1.15

5.36

2.10

1.27

1.37

1.18

16.46

30.19

9.74

9.28

13.69

8.73

21.11

58.08

9.53

12.41

8.315

79.90

9.00

87.80

24.8

44.1

19.9

44.3

22.0

82.0

41.5

73.0

88.9

93.6

11.0

70.4

77.0

83.7

$67 \cdot 55$

60.90

49.93

40.03

34.51

46.55

43.83

54.99

40.88

24.28

7.55

35.17

13.78

8.33

7.74
1. Sudan grass

2. German millet

3. Oat straw

4. Rye straw

5. Timothy

6. Corn stover

7. Red clover

8. Alfalfa

9. Buckwheat hulls

10. Cottoneed hulls

11. Sor ghum

12. Tobacco

13. Aung 1

3.4. Scareed

15. Club moss

16. Horsetalls

17. Fern

18. Buttercup

19. Buckwheat

20. Fung1

21. Smartweed

22. Penner

23. Potato top

24. Tomato top

25. Arr 1 choke

26 . Bidens

27. Ragweed

8.99

28. Xanthium

\section{Sand}

All died.
Av.dry $\&$ of wt.in $g$ control

$4.82 \quad 37.00$

$10.21 \quad 78.20$

$2.47 \quad 18.90$

$1.43 \quad 10.95$

$1.36 \quad 10.42$

$1.82 \quad 12.94$

$4.32 \quad 33.10$

$11.39 \quad 83.79$

$1.96 \quad 15.00$

$1.55 \quad 11.87$

$14.60 \quad 107.62$

$0.75 \quad 20.10$

$4.61 \quad 123.60$

$1.06 \quad 28.40$

$1.22 \quad 32.70$

$0.69 \quad 13.50$

$2.12 \quad 56.80$

$0.72 \quad 19.30$

$3.15 \quad 8 \% .50$

$2.17 \quad 59.20$

$2.70 \quad 72.40$

$5.80 \quad 155.50$

$2.20 \quad 59.00$

$0.40 \quad 10.70$

$2.51 \quad 67.30$

$2.62 \quad 95.70$

3.57
Sand and Lime

1. Sudan grass

2. German millet

1.26

1.53

64.30

3. Oat stram

4. Bye stran

5. Timothy

6. Corn stover

7. Red clover

8. Alfalfa

1.02

1.11

1.31

1.31

$1.4 \overline{4}$

1.14

9. Buckwheat hulls

10. Cottonseed hulls

1.50

1.12

11. Sor ghum

12. Tobacco
0.89

5.63
78.40

52.50

56.70

66.80

66.80

74.00

58.10

76.50

57.10

45.70

287.20 
TABLE XI - Relative growth of barley plants in so1l and in sand with and Whout lime to which had been added equal quantities of nitrogen from different plent tismes.

Soll Unlimed

$\%$ of

Control

Soil Iimed

q of Control

1. Tomato

94

2. Potato

89

3. Seaweed

87

4. Xanthium

84

5. Knotweed

82

6. Tobacco

80

7. Ragweed

8. Peprer

77

9. Bidens

10. Amaranth

11. Cabbage

- 70

12. Alfalfa

13. Pursley

62

61

58

14. Canada blue graso

58

15. Onion

16. Kentuciky biue

55

47.

17. Buttercup

18. Horsetalls

$41+$

19. Tumnip top

20. Smartweed

21. Sweet clover

22. Orchard grass

23. Moss Halrs cap

44

44

42

40

40

24 .L ambs quarter

35

25. German millet

2€. Carex lupul Inus

35

30

25

27. Club moss

28. Buckwheat

24

22

29. Red clover

21

30. Fern

20

31. Sudan gras:

16

32. Timo thy

33. Care atricta

14

34. Cottonseed hulls 12

35. Ait 1 cholo

11

36. Oat strav

37. Buckwheat hulls

10

38. Rye strair

39. Fungt

40. Cladiolus

41. Corn stover

42. Sor ghum

43. 71 tch grass

4h. Red top

145. Juncus of fusus

10

1. Potato

2. Seaweed

3. Tobacco

4. Xanthium

5. Alfalfa

6. Knotweed

7. Bagweed

8. German millet

9. Pepper

10. BIdens

11. Eomato

12. Suar tweed

13. But tercup

14. Sudan grass

15. Red claver

16. Horsetalls

17. Club moss

18. Fung1

19. Buckwheat

20. Oat straw

21. Fern

22. Buckwhe at hulls

23. Corn stover

24. Cottonseed hulls

156

124

108

96

87

85

78

78

72

67

59

58

37

33

28

20

19

19

18

15

14

12

11

$\begin{array}{ll}26 . \text { Artichoke } & 11 \\ \text { 27. Timathy } & 10\end{array}$

28. Sor ghum

Sand timed

1. Tobacco

287

2. German millet

3. Buckwiseat hulls

7.. Red clover(dead)

5. Timothy

6. Corn stover

7. Sudan grass

8. Alfalfa

9. Cottonseed hulls

10. Rye straw

78

76
74

67
67

64

58

11. Ont straw

57
57

12. So rghrm

53

46 
Table III shows the results of treatments 1 through 12 inclus-

ive. Where the dash appears it indicates that there was less than . 5 p.p.m. of nitrogen present. The results show that tobacco, alfalfa, and red clover were readily decomposed, ranklng in the order given. The grams of carbon added were in the orner 11 sted $5.7,8.7$, and 11.8. German milet and gudan grass were slower in lecomposition, though in the ond approaching red clover. Oat straw, timothy and corn stover treatments vere mach sluwer in comparison with the cthers menioned, and hardy reached the level of nitrates in the orieinal soll. All other treatments need time In ercess of 8 weeks for the nitrates to reapoar after disantoaring. In tre case of the sand cultures nitrification was much slower as nitrates appeared only in tobacco and alfalfa. Amonins nere higher in the sand than in the soil, robably due to the reaction and insufficient nitrifying organisms.

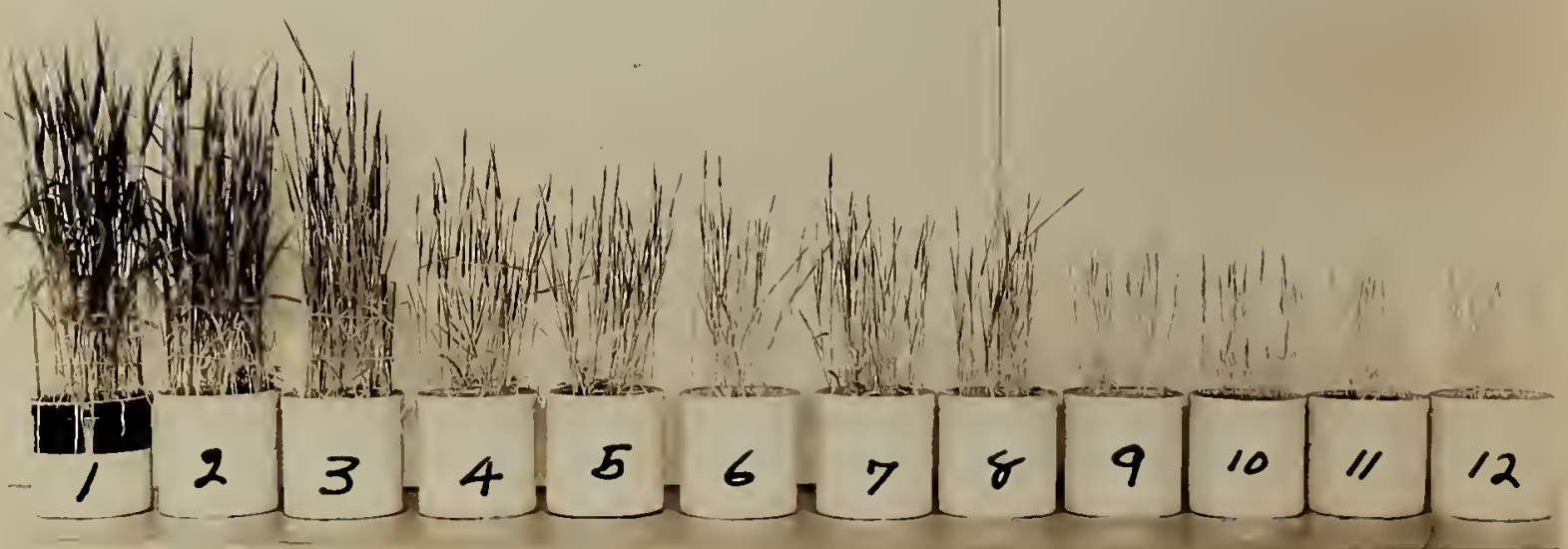


Fig. I, (Treatments 1 - 12) shows the barley growth in soil from an equivalent quantity of nitrogen from: 1 - sodium nitrate, 2 tobacco, 3 - alfalfa, 4 -German millet, 5 - red clover, 6 - cottonseed hulls, 7 - sudan grass, 8 - timothy, 9 - oat straw, 10 - buckwheat hulls, 11 - sorghum, 12 - corn stover.

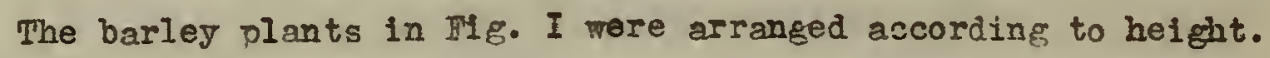
The plant indications of decomposition follow closely that of the ammonification and the nitrification test. Tobacco and alfalfa treatments were very similar to the check. German millet, red clover, cottonseed hulls, sudan grass and timothy treatments forned an inter. mediate group between the extremes. Rye straw was unintentionally omitted and rould be above or below buckwheat hulls.

Tobacco and alfalfa were as good as the check at the end of 30 days, and were heading at the end of 60 days. $A 11$ others were dying from the tips back at the end of 30 days. Table $X$ and XI Iist the data on the barley gromth and the percentage of control. 

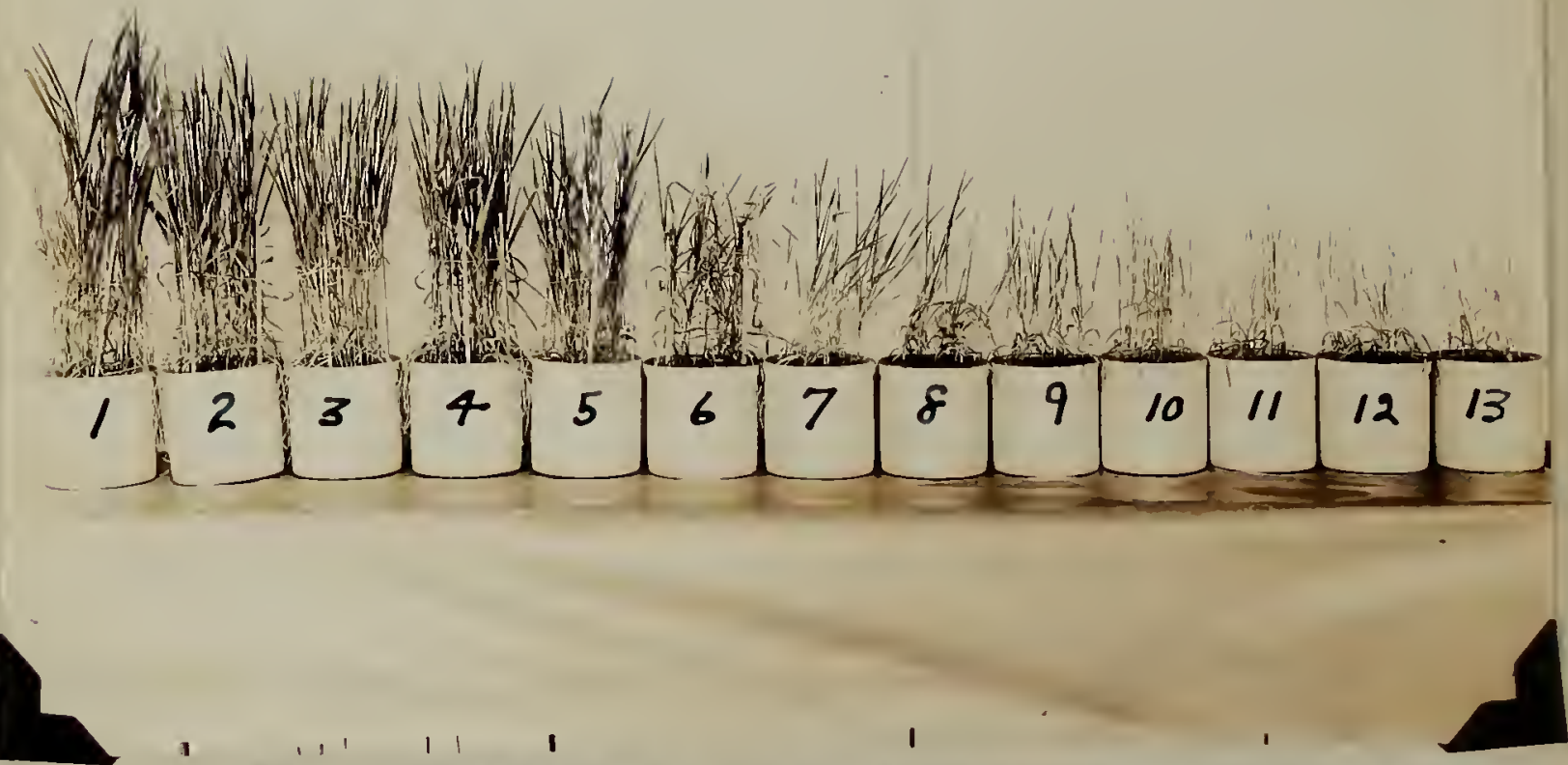

1. 1 1 1

FIg. II (Treatments I - 12) shows the barley growth in Iimed soll arranged according to helght from .41 grams of nitrogen from the following: 1 - check sodiun nitrate, 2 - tobacco, 3 - German millet, 4 - alfalfa, 5 - sudan grass, 6 - red clover, 7 - oat straw, 8 - corn stover, 9 - timothy, 10 - buckwheat hulls, 11 - cottonseed hulls, 12 - rye straw, 13 - sorghum.

In grams of dry welght. lime reduced growth in the following treatments: rye straw, timothy, cottonseed hulls and sorghum: in all others It increased the grams of dry weight produced. This group could be divided as follows: tobacco, millet, alfalfa and sudan grass treatments approaching the check, all others with red clover treatment first followed by oat stran and com stover treatments producing intermediate or poor growth. 


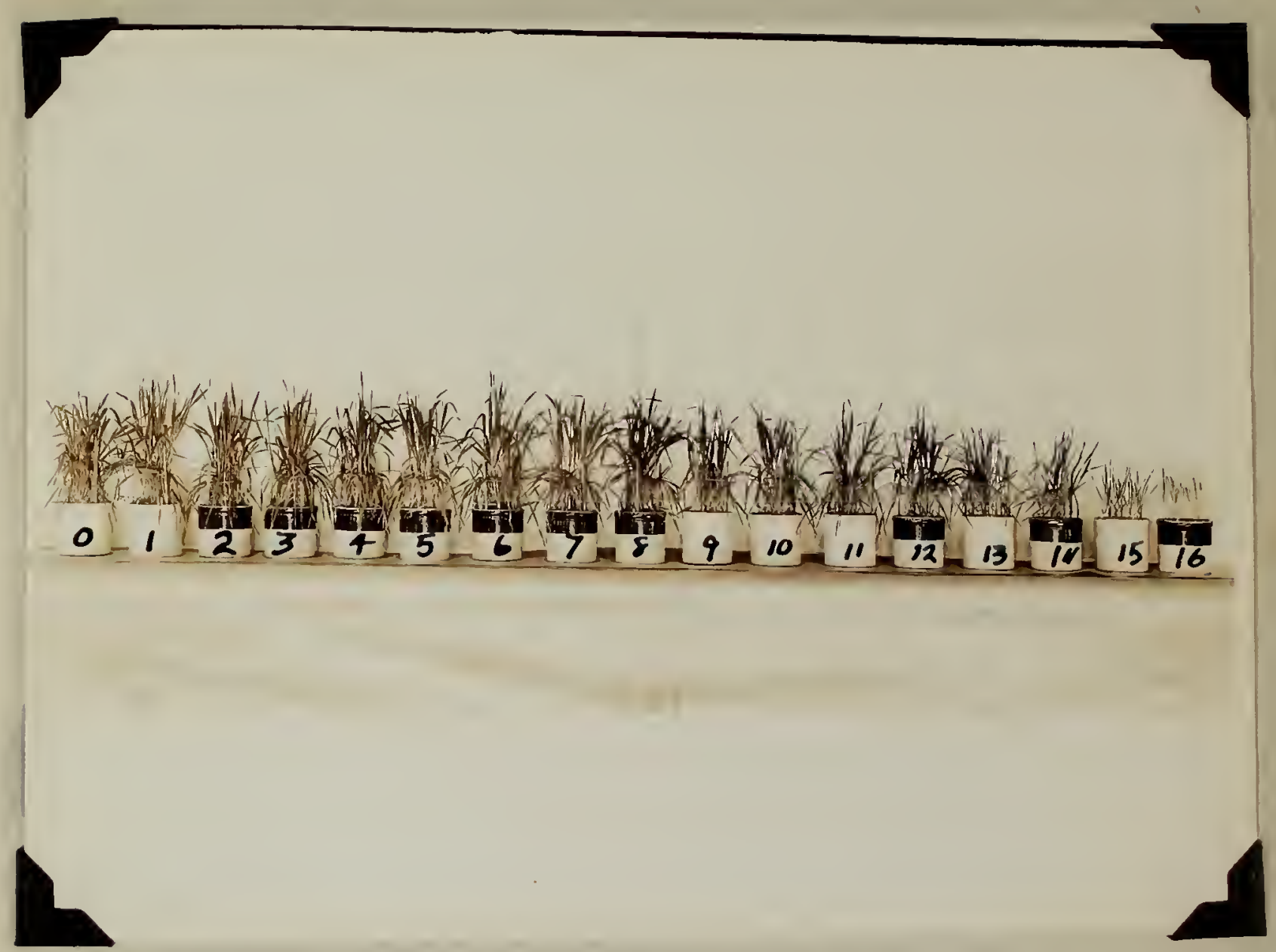

Fig. III (Treatments 13 to 28 inclusive) shows the barloy growth in soll arranged according to helght from .41 grams of nitrogen from the plant tissue listed es follons: 0 - control sodium nitrate, 1 - seaweed. 2 - xanthium, 3 - pepper, 4 -tomato, 5 - motweed, 6 - ragweed, 7 - bidens, 8 - potato, 9 - buttercup, 10 - horsetails, 11 - club moss, 12 - smart weed. 13 - fern, 14 - buclcwheat, 15 - fungl, 16 - artichoke.

Tables IX, X, and XI (treatments $12-28$ inclusive) also figures 1,2 3 and 4 are showing the same thing in a different way. Table XI shows a 
rating in soll based on the ppm. of armonia as nitrates formed. Table $X$ shows the results of the same treatments from plant growth, and figures 1, 2, 3. and 4 are 1llustrations of $x$. Table $x$ also shors the actual dry rrelghts produced in grams. Art1choke, fungl, and club moss did not nitrify in the perlod of this experiment. Ferr, buttercup and buckwheat were found to be marginal, between those that did nitrify and thost that did not.

Family relationships in the solanaceae were very similar as to gropth indications. Polygonacea were not as uniform as the solanaceae. Compositae were very uniform eliminating artichokes. Seareed as good as the check.

mreatments 29 to 45 inclusive were arranged in the order of decreasing nitrogen content. This order was selected in order to 11lustrate what actually havoned in regard to the order of decomoosition.

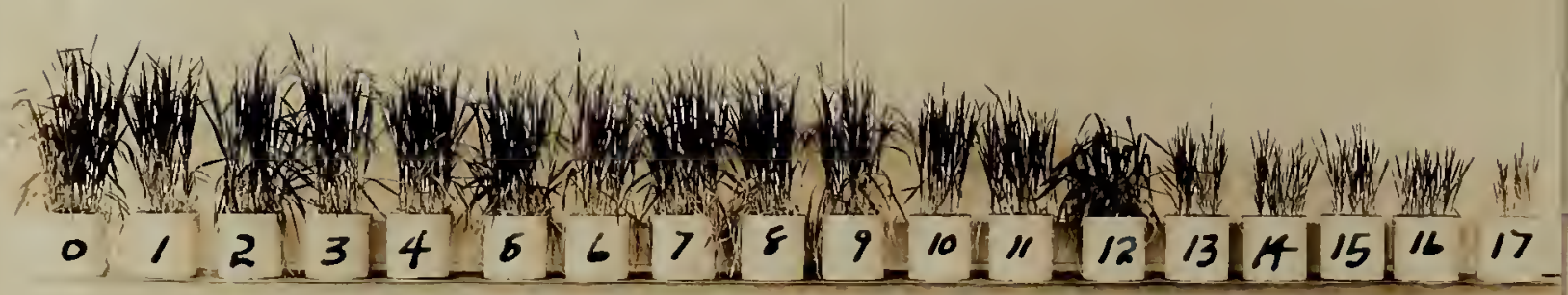


Fig. IV (treatments 29 to 45 inclusive) shows the barley growth in soll arranged according to helght from .41 grams of nitrogen from the following plants: 0 - control, 1 - Kentucky blue grass, 2 - cabbago, 3 - turnip top. 4 - onion, 5-pursley, 6 - orchard grass, 7 - amaranth, 8 - Canada blue, 9 - sweet clover, 10 - moss hairs cap, 11 - carex lupul1nus, 12 - lambs quarter, 13 - carex stricts, 14 - juncus effusus, 15 - witch grass, 16 - gladiolus, 17 - red top.

Thirty dass after planting treatments $1,2,4,6$ and 12 were better than the checks, family correlations showed that Ganadian blue was the best of the monocotyledons followed by Kentucky blue and orchard grass in the order given. At harresting all plants including the controls were aring from the bottom un. Numbers 5 - pursley and 12 - lambs quarter were the greenest of any of the treatments. Gromth in all of the moncotyledons were similar, 1.e. upright, stiff straw, with little stooling. Pursley, amaranth, cabbage and sweet clover treatments showed a different kind of behavior, weakness of straw and leaves. Orchard grass and turntp tops treatments were beginning to head. Pursley, amaranth, cabbage, and lumbs quarter treatments were green and showing signs of excessive nitrogen. Stooling was in the order of the arrangement from oursley to sweet clover treatments with none beyond. 
TABLE XII A - A rating of barley growth produced from nitrogen evolved from plant tissue listed.

TABLE XII B - Rating from the amonification and nitrification test based on ammonla and nitrate nitrogen produced

from controls.

A

Vegetation Test

1. Tobacco

2. Potato top

3. Seaweed

4. Xanthium

5. Knotweed

6. Ragweed

7. Toinato

8. Pepper

9. Bidens

10. Alfalfa

11. German Millet

12. Amaranth

13. Cabbage

14. Fursley

15. Canadian blue grass

16. Buttercup

17. Onton

18. Snartweed

19. Kentucky blue grass

20. Turnip top

21. Red claver

22. Sweet clover

23. Orchard grass

24. Sudan grass

25. Horsetails

26. Noss hairs cap

27. Lambs auarter

28. Buckwheat hulls

29. Timo thy

30. Corn stover

31. Oat straw

32. Cottonseed hulls

33. Pye straw

34. Club moss

35. Carex luvulinus

36. Sor ghum

37. Buckwheat

38. Pern

39. Pungt

40. Carex stricta

41. Arti choke

42. Glad1011

43. initch grass

44. Red top

45.Juncus of fusus
158.0

122.0

105.0

90.0

83.0

77.0

73.0

69.0

68.0

62.0

62.0

61.0

58.0

55.0

51.0

50.0

59.0

42.0

43.0

41.0

40.0

39.0

38.0

35.0

35.0

33.0

30.0

30.0

27.0

27.0

26.0

25.0

214.0

21.0

21.0

19.0

15.0

14.0

11.0

9.0

8.0

8.0

8.0
B Anmonification and Mitrification Test

1. Tobacco

2. Potato

118.0

3. Pursley

4. Tomato

5. Alfalfa

6. Lambs quarter

7. Amaranth

8. Cabbage

9. Seare ed

10. Xanthium

11. Knotweed

12. Pepper

13. Kentucky blue grass

14. Onion

109.0

107.0

102.0

100.0

100.0

99.0

94.0

82.0

74.0

63.0

59.0

58.0

57.0

57.0

56.0

52.8

52.0

43.0

41.0

40.0

38.0

33.0

27.0

24.0

23.0

20.0

14.0

13.0

13.0

12.0

11.0

9.0

8.0

7.0

7.0

6.0

4.0

4.0

3.0

3.0

3.0

2.0

1.0 
TABLE XIII - Family grouping based on nitrification and anmonification percentages of the control.

$\begin{array}{llrl} & \text { Tobacco } & 1 \% & \mathbb{N}-\mathrm{C} \\ 2 & \text { Potato top } 109 & 1-13 \\ 3 & 1-25 \\ 3 & \text { Tomato top } 102 & 1-12 \\ 12 & \text { Pepper top } 59 & 1-15\end{array}$

\section{Legumino seae}

5 Alfalfa $100 \quad 1-20$

16 Sweet

clover $56 \quad 1-29$

21 Fed clover 41 1-27

Compositae

$\begin{array}{llrl}10 \text { Xanthium } & 74 & 1-21 \\ 15 \text { Ragweed } & 57 & 1-21 \\ 17 \text { Bidens } & 52 & 1-18 \\ 43 \text { Articholce } & 3 & 1-68\end{array}$

\section{Nonocotyledonae - Grasses}

\& $\mathrm{N}-\mathrm{C}$

13 Kentucky blue erass 58 1-19

14 Onion $57 \quad 1-15$

18 Canadian biue grass 52 1-20

19 cerman millet $52 \quad 1-30$

23 Suden Erass $38 \quad 1-34$

24 Orchard grass $33 \quad 1-19$

28 Oat stram 20 1-48

29 Corn stover $\quad 14 \quad 1-45$

30 Timothy $13 \quad 1-58$

31 pye straw 13 1-89

33 Sorghun $11 \quad 1-75$

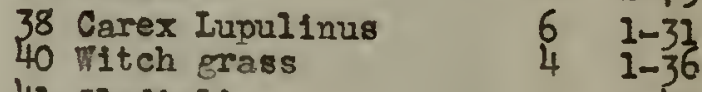

41 Gladioli 3 1-40

42 Red top $\quad 3 \quad 1-55$

44 Juncus effusus $2 \quad 1-33$

45 carex tricta $11-35$

\section{Others}

3 Pursley $107 \quad 1-8$

Lambs

quarter $100 \quad 1-17$

7 Amaranth 99 1-11

30 Tumip top $43 \quad 1-19$

26 Buttercup $24 \quad 1-23$

35 cottonseed

hulls $8 \quad 1-83$
Non Vascular Plants

Seaweed
Moss Hairs cao
Horsetalls
Fern
Fungl
club moss

$\begin{array}{ll}82 & 1-19 \\ 40 & 1-27 \\ 23 & 1-28 \\ 7 & 1-43 \\ 7 & 1-44 \\ 6 & 1=56\end{array}$

\section{Polygonaceae}

11 Knotweed $63 \quad 1-19$

25 smartreed $27 \quad 1-24$

32 Buckwheat i2 $1-29$

3) Buckwheat hulls

$9 \quad 3-96$

In the case of Polygonacea the nitrification fating follows the nitrogen-carbon ratio, this was followed al so in the case of the lower forms of plants. In the majority of cases the nitrogen-carbon ratio was not followed. 
TABLE XIV - Clasgif1cation based on average percenteges of control from vegetation test and armonification test.

1. Tobacco

$$
\&
$$

$\mathbb{N}-\mathrm{C}-\mathrm{B}$

2. Potato

3. Seaweed

4. Tomato

5. Alfalfa

6. Pursley

7. Xanthiun

8. Amaranth

82

9. Cabbage

80

10. Kno treed

11. Lambs quarter

12. 7agweed

13. Pepper

14.B1dens

15. German Millet 16. Onion

17. Kentucky blue grass

76

73

67

67

61

$1-13$

$1-25$

$1-19$

$1-20$

$1-8$

$1-21$

$1-11$

$1-12$

$1-18$

$1-17$

$1-21$

$1-15$

$1-18$

57

54

$1-30$

$1-15$

18. Canada blue grass

19. Sweet clover

52

49

20.0at straw

47

21. Turnis top

22. Red clover

23. Sudan grass

24. Buttercup

25. Smartireed

26. Moss halrs cap

27. Orchard grass

28. Horsetalls

29. Corn stover

30. Timothy

31. Buckwheat hulls

32. Club Moss

33. Sor ghum

34 . Buckwhe at

35. Fire straw

36. Carex lupulinus

37. kern

38. Cottonseed hulls

43

39

$1-20$

$1-29$

$1-48$

$1-19$

$1-27$

$1-34$

$1-23$

38

$1-24$

38

37

$1-27$

31

$1-19$

22

22

21

16

16

$1-28$

$1-45$

$1-58$

16

$1-56$

$1-75$

14

$1-29$

14

$1-89$

13

12

$1-43$

11

40. Carex stricta

41. Artichoke

42. W1 tch grass

43. Gladioli

44. Red top

45. Juncus effusus

Ilst of materials studled arranged in the order of highest percentages of controls from the nitrification and the anmonification test, without regard to family relationship or chemical composition. 
TABLE XV - Pamily grouplng based on regetation and nitriflcation average percentaga.

\begin{tabular}{|c|c|c|c|}
\hline Ronk & Sol.anserac & \& & $3-2-\mathrm{R}$ \\
\hline 1. & Tobacco & 138 & $1-13$ \\
\hline$\frac{2}{4}$ & $\begin{array}{l}\text { Potato tops } \\
\text { Tomato top }\end{array}$ & $\begin{array}{r}115 \\
89\end{array}$ & $\begin{array}{l}1-25 \\
1-12\end{array}$ \\
\hline \multirow[t]{3}{*}{13} & Pepper tops & 65 & $1-15$ \\
\hline & Average & 102 & \\
\hline & Compositao & & \\
\hline \multirow{4}{*}{$\begin{array}{c}7 \\
12 \\
24 \\
41\end{array}$} & Xenthiven & 82 & $1-21$ \\
\hline & $\begin{array}{l}\text { Pagmeed } \\
\text { Bt.dens }\end{array}$ & $\begin{array}{l}67 \\
61\end{array}$ & $\begin{array}{l}1-2 \\
1-i\end{array}$ \\
\hline & Artichoke & 70 & $1-$ \\
\hline & Averago & & \\
\hline
\end{tabular}

L.egnufucrseae

$\begin{array}{rlrr}5 & \text { Alfalfa } & 84 & 1-20 \\ 19 & \text { Sweet clover } & 149 & 1-29 \\ 22 & \text { Red clover } & 42 & 1-27 \\ & \text { Average } & 53 & \end{array}$

\section{Polygonacese}

10 knotweed

25 Snartweed

31 Buclowheat hulls

34 Buckwheat 16 average 37

\section{nthers}

\begin{tabular}{|c|c|c|c|}
\hline \multicolumn{2}{|c|}{ Bank } & & $\mathbb{B}-\mathrm{C}-\mathrm{R}$ \\
\hline 6 & turgley & 83 & $1-8$ \\
\hline $\begin{array}{l}8 \\
9\end{array}$ & $\begin{array}{l}\text { Amarenth } \\
\text { Cabhage }\end{array}$ & $\begin{array}{l}80 \\
76\end{array}$ & $\begin{array}{l}1-11 \\
1-12\end{array}$ \\
\hline 11 & Lanos quarter & 67 & $1-17$ \\
\hline $\begin{array}{l}21 \\
24\end{array}$ & $\begin{array}{l}\text { Tumid fop } \\
\text { Battercup }\end{array}$ & $\begin{array}{l}43 \\
38\end{array}$ & $\begin{array}{l}1-19 \\
1-23\end{array}$ \\
\hline $3 \varepsilon^{\circ}$ & $\begin{array}{r}\text { Cottonseed } \\
\text { malls }\end{array}$ & 12 & $1-83$ \\
\hline & Average & & \\
\hline
\end{tabular}

Uon vascular plante

$\begin{array}{llll}3 & \text { Soewsed } & 98 & 1-19 \\ 26 & \text { Hoss halrs car } & 38 & 1-27 \\ 28 & \text { Iorsetalis } & 31 & 1-28 \\ 32 & \text { Club moss } & 16 & 1-56 \\ 37 & \text { Ferm } & 13 & 1-43 \\ 39 & \text { Fung: } & 11 & 1-44 \\ & \text { Averise } & 34 & \end{array}$

\section{Monocotyleiloneac}

15
16
17
18
20
23
27
29

17 Eentucky blue

\section{7}

$5^{44}$

52

1.30

$1-15$

$1 \cdots 19$

$521-20$

18 Canadian filue

20 oat straw

23 sudan erans

27 Orchard grass

29 Corn stove:

30 Fimothy

33 Sorghum

34 इyo atra

36 Carex lupui inus

40 Carex sticts

42 teh grass

43 QI.d1011
$47 \quad 1.48$

$39 \quad 1-39$

$22 \quad 1-19$

$22.1-58$

$16 \quad 1-75$

I!: $1-39$

$13 \quad 2-31$

$121-30$

$6 \quad 1-35$

$51-55$
Lonocotyledonezo

$\begin{array}{lll}\text { lith led ton } & 5 & 1-55 \\ 45 \text { Juncus ef rusus } & 5 & 1-33\end{array}$

Averace

28 
The nitrate snd aminonia determinations vere carried out in 3 groups as follows: treatments 1 - 12 inclusive under similar conditions of length of day and temperature, treatments 13 to 28 inclusive, and 28 to 45 inclusive.

Under the conditions of the investigation the addition of the following materials need time in excess of the period of the duration of the experiment as can be seen from Tables III, V, and VITI: oat otraw, rye straw, timothy, corn stover, buckwheat hulls, cottonseed hulls, sorghum, club moss, fern, buckwheat, art1chole, carex lupulimus, juncus effrasus, carex stricta. witch grass. gladiolus, and red top. All other nitrates were Formed of ther immalately or during the duration of the exoeriment.

Tobacco, seameed, potato tops, tomato tops, penper, knotweed, alfalfa, pursley, amaranth, lambs quarter, cabbage, bidens, xanthium, ragmeed, decomposed tmediately and nitrates appeared in the soll immediately or at the exolration of I week.

Thers were others such as the clovers, mlliet, sudan grass, the blue grasses, onion, horsetails, smartweed, which were intormediate between the two extremes. The moisture content for the corregoonding nitrate and ammonia ceterminations fluctuated from 17 percent in ragweed treatments to 29 percent in the sorghum treatment.

In the limed soll and sand the addition of limestone reduced the pom. of nitrates produced in conparison to the unlimed soil. The limed soll treatments included 1 to 29. The moisture for this period Iluctuated between 21 percent in bidens and buckwheat mulls to 29 percent in artichoke. whibh was slightly higher than in soil without lime.

The dry weight of barley produced from these various plant tissues 
as nitrogen sources was reduced in treatments 13 to 29 , but in treatments 1 to 12 there was an increase in dry reight produced from the addition of lime.

In the Solenaceae, Compositro, and Leguntnoseae the rank in the family grounings are the same in the vegetation test and the nitrification test. The nitrogen-carbon ratio, however, ranges from 1 to 12 in tomato tops to 1 to 29 in sweet clover (artichoke eliminated as a misnomer as tt rrer broadcast and ras woody and had lost three-fourthe of its leaves when collected.) In tile Poljgonaceae vegutation test buckwheat hulls showed up better than did buckwheat, but the order was rem versed in the nitrification test. A nitroesen carbon-ratio of 1 to 96 was better then a nitrogen carbon ratio of 1 to 29 . Ne1ther was the car bon-n1trogen ratio nor the total nitrogen content followed in elther case.

In the dicotyledonous plents with a total nitrogen content of 2 percent or more the nitrogen-carbon ratio or the total nitrogen content aifect but jititio as nitrates reappear in from 1 week to $l^{\text {li }}$ davs, wher finely ground and incorporated in the soil. In the case of potato tops with a nitrogen content of 1.48 percent nitrates were avallable the first week but in the case of the monocotyledonous plants. orchard grass with a total nitrogon content of 2.54 percent, the nitrates did not exceed that of the originnl soll until the 4 th week. These results are shown by the reekiy Pluctuatious of amnonification and nitrification in Tables III, $\nabla$ and VII, and in figure 1 to 7 acpendix showing the weekly fluctuations in parts per miliun of nitrogen in individual plants listed.

The results are suggestive of the 1dea of the structure of the nlent and their protective maxes and rosins as controling factors in decomosition associatod with the rater soluble materials in the olant. 


\section{DISCUSSION}

The following questions were in mind when this experiment was planned.

Is there a relationship between the characteristica of plant: (such as reproductive mechanisms) by which thes are at prosent olisalIled Into familes, and the rate of their decomposition when they are Incorporated in the soll?

Is there a relationship between the total nitrogen-content of plants and the rate of decomposition?

Is there a relationship between the carbon-nitrogen ratio and the rate of decomposition?

Is there a relationship between the Iignic-acid content of plants and the rate of decomposition?

Is there a relationship between the content of pentosans and the rate of decompostion?

Is there a relationship between the rate of decomposition and the characterlstics of plants (such as their position in the erolutionary series) by wich they are sometimes classifled into "natural" families?

The results of this experiment al so opon up many other interestIng questions for the solution of which the data obtained is insafficient.

Tables XIII and XV (11sting family groupings) show how under the conditions of moleture, temperature, and preparation in this experiment plants of the same family tend to group theneelves with respect to 
readiness of decomposition. Flgure I to Appendi $x$ VII shows in a $11 t-$ tie more detall the veekly fluctuations in the amounts of nitrate and ammon1a Iiberated by these Individual members. (Individuals of the same famiIy observed under the conditions of this experiment and cut dorn under similar conditions by srowth and at similar stages of developmant break down simflarly.) The smaller the number of representatives used the narrower 1s the range of Fluctuations: and as a study of the monocotyledonous group shows, the larger the number, the wider is the range of fluctuations. There 1s, consequently, a narrover range of fluctuations anong members of families in the dicotyledonous group than among member of the monocotyledonous group of plants. This relative uniformity may be the result of the fact that fewer representatives of the alcotyledons were observed, or that the conditions under which the members of this family grew were more nearly similar, or that, because they decayed more rapidy, their decomposition was elther less complex or less accurately recorded. There are also similarities in the behavior of certain menbers within families. Thus the blue grasses, sudan grass, orchard grass, and onfons, all of which are calciphiles, all broke down very rapidy. But there are, to be sure, other calciphlles such as sorghum and timothy, that required more than elght reaks for complete disintegration.

There is a positive correlation of $.81 \pm .035$ betreen amonification tests and total nitrogen-content of the plants studied. The larger the percentage of total nitrogen, the sooner the plant (when finely ground and incorporated in the so11) begins to Iiberate and add Its 
nitrates to those of the origlnal soll: and the more rapid thereafter is tho rate of liberation. But when the percentage of total nitrogen is more than 1.50 percent in dicotyledonous plants, or 2 percent in monocotyledonous plants, nitrates should appear from them in the soll within approximately 14 days. There was, however, little if any correlation between the total nitrogen-content of the members of families of plants and their position in the usual classification. There was, however, a surprisingly close (probably fortultious) relationship between the three members of the Compositae studied with respect to total nitrogen-content.

There was some relationship between the groupings of plants into fanllies and the carbon-content of the separate members: this relationahip was closest among the dicotyledons, but appeared to be a more or $168 \mathrm{~s}$ conotant factor for all the plant: studied. (The largest percentages of carbon Fere found in the monocotyledonous plants.) But it seens cloar to the writer that a high nitrogen-content is seldom associated wth a high carbon-content (there was found, Indeed, to be a negative correlation of $.53 \pm .07$ between the two): and as the carbon-content increased, the nitrogen content usually decreased. The larger the carbon-content, the slower was the rate of decomposition: for a large content of carbon was usually to be found wth a $10 \pi$ content of nitrogen, and a low content of nitrogen in an organle fertilizer always results in a nitrogen depression in the soll. and, of course a consequent falling off in the fleld of crops.

Onder the conditions of this experiment the carbon-nitrogen ratio cannot be relled upon to predict which of two plant-materlal or organic mubstances wil be nitrifled the more readily. The writer found that plant-tisue with a nitrogen-carbon ratio of 1 to 25 - 30 was very readily 
decomposed to gleld up 1 ts aftrates. As the ratio docreased from 1 to 25 - 30 to 1:to 8 (the normal ratio of nitrogen to carbon in the so11s) the balance of organl sms in the soll is less violently disturbed, and the nitrate given wo in decomposition soon appear. The nitrogen-carbon ratio can be used, however, to predict the relative raplalty at which nitrates given up in decomposition may be expected to appear in the s011: or, vice-versa the relative nitrogen depression, generally opeaking. of crops. Table XII and XIV show these relationships.

It w11l have been observed by the reader of the Revlew of the Ilterature that the IIgnin-content in plants is a large contributor to humus. Now in 1ts process of decay, humal at first noticeably deteriorates: but it soon reaches an oquilibrium, after phich decomoosition is so slow that Iignic materials tend to accumulate, and the proportion of Iignic-content in the soll to increase. Thus, there was a negative correlation of $.357 \pm .08$ between the I1gnic content of plants and the parts per mililon of nitrates formed. The higher the IIgnic-content, too, the slower the rate of deconposition: for the lignin as ligno-cellulose tends to shield the cellulose from decomosition by soll organisms. (Faksman has shom that plant tissue from which the 11 gnic content has been remover. decays readily.)

So $f a r$ as the rate of decomposition is concerned, there was also a negative correlation of $.474 \pm .02$ between the results of the nitrifieation-test and the percentage of pentosans in plants: in other words as the pontosans increased, nitrification decreased. The results are remarkably and sienificantly similar to those of the carbon and nitrogen tests. There was, on the other hand a nositive correlation of $.450 \pm .08$ betreen 
the content of pentoran end the contert of lignic ndid: as one increased, so did the other. These are vrecisely the results one would expact, and the two tests seem to substatiate each other. In short, as the total nitrogeumcontent decrensed, the percentage of vontosans inereased. How, In order to maks clear still further applications of the rasults of this experiment to the "natural" elassification of plants, It will be necessary to state one assumction on which all such claselfications depend. It is assumed by stadents of botanics I (and other) evolution that various forms have developed on the esth at different rates over the same pertod of time: for only br euch an assurrotion, apparently, is it possible to explain the contemoraneou nresence of aimple, unadapted form on the one hand. and complex, highly soectelized forms on the other. Thus, certain plants were at some older enoch forced so to adapt themselve to their environment as to evolve a. very high tolerance for nitrogen: while others, Iiving in the same epodi but pre sumaily under other conditions, escaned this necessity altogether. Today. therefore, the one species contains a relatively largo vroportion of nitrogen. and tho others a relatively small poportion: and it seems evident (granting the original assumotion) that a corrollary of it must be al go true: that the very existence of the f1sst mpecies proves the existence at an earlier opoch of an environment which somehow forced nitrogen upon plants in musual amounts. If this original assweption and 1 ts corollary be admitted, then this experiment shows that as the dicotyledon were developing as a distinct order, there mist hare been what ray be called for the seke of brevity a nitrogenous enviromment: that that this nitrogenous environment mat have faded bofore the 
-volution of the monocotyledons, which contaln less nitrogen. It may we Inquired, Indeed, whether there was not some sort of correlation botween the "n1trogenous onvironment" and the vrolution of the two seed leaves of the dicotyledons.) Thas, such lon forms as the 11 cheme. the horectalls, and the club moss contain 11ttle nitrogen and (at least the last two) wrach silica: but a dicotyledon like portralace is Flch in nitrogen. Fith a monocotyledon, like rye, however, the total nitroger content is exceedingly wall.

The mention of the proportion of silica in plants leads to a st11l further development of the theory of enviromments at older epoch. which were characterized by a predominance of one or a few elements or comoounds. It has just been remarked that the "nitrogenous environment" in which the dicotgledons appear to have erolved had faded before the monocotyledons were developed: 1 will be recalled, too, that as the content of nitrogen decreased, that of the pentosans roughly increased. Iow.1t seens to follow conversely that if a steady increase in the proportion of the pentosans in the higher members of the evolutionary ser1es can be showa. 1t 1 s safe to assume (even whout apalytical proof) that the proportion of altrogen mast be steadily declining: Indeed, that the "nitrogenous onvironment" is waning. The ratio of percentage: of silice to nitrogon indicate (as the accompanying tablo show) exactly the same recesalon of nitrogen before the adrance of another, opposed constituent of plint-t1soue. If, then (as seems I1kely from the foregoing comparison of nitrogenous content with position in the evolutionary 
cories) "nitrogenous environments" come and go in egcles, the oteady increace of the proportione of sllica Indicate that the botanical world is nor in the downard curre of a cyclo. Thus, the proportion of allica in the plants at the bottom of the evolutionary series is negligible: it inereasen in the higher order of Pteridophrtes (such as the horwetalle): 1 t decreases, however, in the still higher ordor of dicotyledons: but galne once more in the monocotyledons, the highent of the orders included. In the experiment.

\section{Table of Proportions of Silica and Iimo in Monocotylodon: and Dicotolydon.}

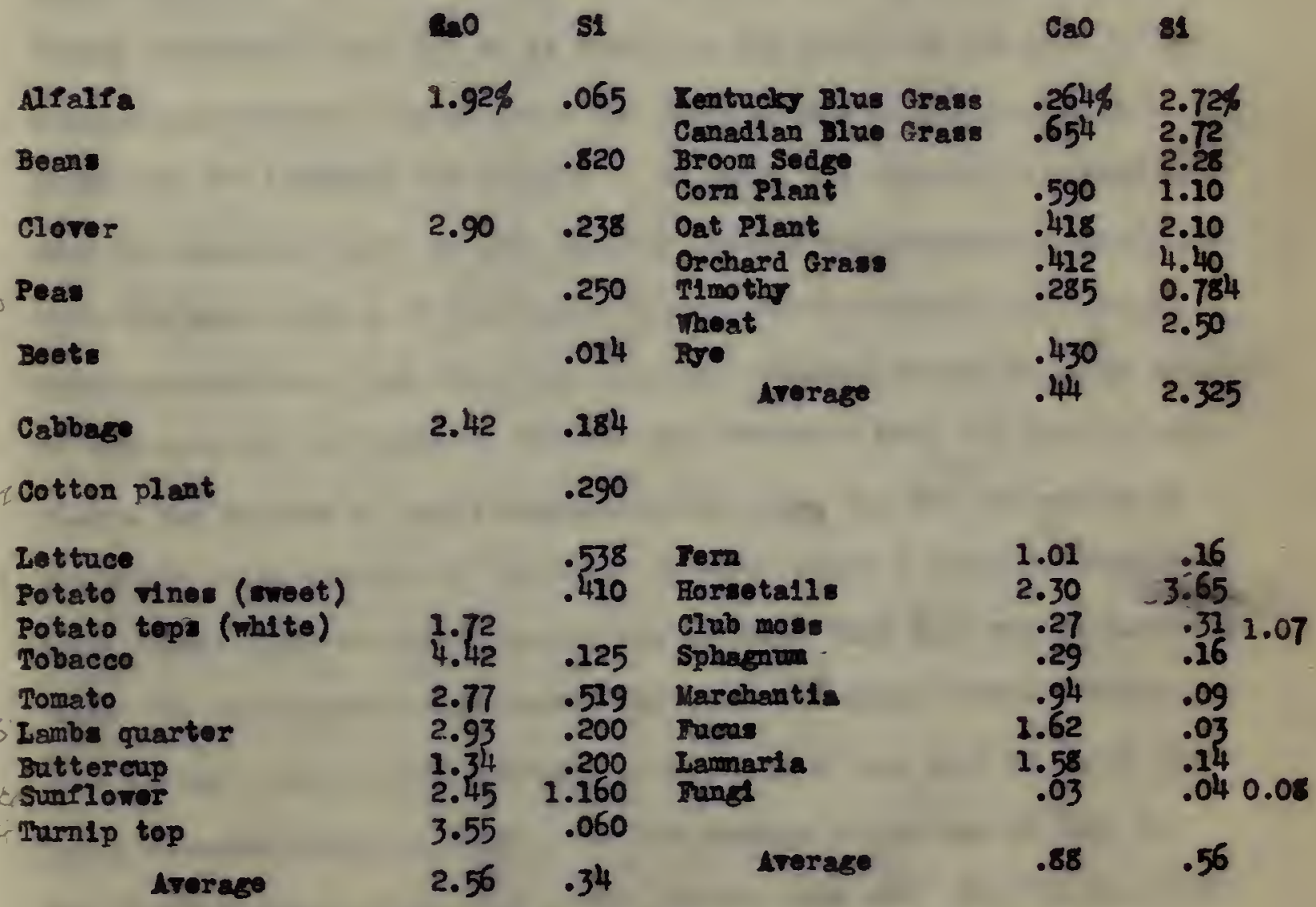

(Comptled from analyees made upon ashes of the plants by Boncaup (19), wolff $(66)$, and Roblason (43). 


\section{$-65-$}

In the same table it is clear that there is a positive (though rough) correlation between the proportions in plants of Iims and nitrogen. Iow wile no Information bat yet been collected to show precisely to tell what the eircumstances are that force plants to tolerate more nitrogen (vhether the cause relates to climatic condstions, nature or the soll. apecies of plants or stage of gronth. or a combination of these, got tentative data have been submitted regarding the elrcumstances which faror the incorporation of Ilme in plants. It may be assumed that there is some correlation between the two: that condition which favor a large tolerance of nitrogen are not unlike those which are falrly certain to favor a largo telorence of 11me. The conditions which favor a large tolerance of $11 \mathrm{mo}$ relate principally (so far as is lmown) to the nature of the 8011 or to Climatic conditions: for at leest the lower orders of marine plants -- the fucres and the lamarla for example - of which the abeorptive organ subsist in wbmarine vo11. 15 any) usually contain proportionately more lime than the lower orders of terraneous plants: hoary rainfall (bscause it Asolves'much I1me from Ilmestone deposts) Ienders unuxually large anount: of the compound avallable to plents: and excessive heat (by forcing upon plents the dofence of rapid transpiration) makes for the aboorption of unumally largo amounte of the vater in which alone a plant can recelve 11me. From these tentative principles at least thie much may be hasarded about the "nitrogenous environment" in wich the dicotyledone ovolved: that it vas a more mo1et, probably warmer period then that in which the later monocotyledons developed: for the arerage percentage of $11 \mathrm{me}$ in the former order 1: 2.56 , and in the latter, only .44. It will be clear. too, that an analyuls of the relative proportions of IIme in plants aleo 
substantiate the "natural" classification.

Mthough the witer feels that the method which he used to determine the lignic content of plants has not jot been perfocted (rould not serve, for example, In the analyals of a wide rango of spectes), Jet the II gures for 11 gnic content obtained by the Imperfect method used are of considerable use, adding st121 further substantiations to the varlous "natural" classifleations of plonts. For the lignic content of the monocotyledons $1 \mathrm{~g}$ higher on the average ( 4 percent) than that of the dicotyledon: (2:50 percoit): and, correspondingly, the former stand higher In the evolutionary series than the latter.

But the correlations botween proportion of pentoeans in plants and their membership in famities are not so definite. To be sure, the propor tion of pentosans in the grasses range from 12 percont in orchard grass to 27 percent in rye straw: and in the night shade family the proportion of pentosans in three out of four epecimens vere very close (7 - 8 ipercent). But tobacco (also a member of the night shade group) contalns 23 percont of pentosans. In the polygonum (without seeds and hulls) the percontage of pentosans ranges from 9 to 15 percent. In the 1 guminosal, the range 1s from 11 to 17 percont. Iot the dicotyledons are, as a rule, poor in pentosans, the average for the group belng but 12 percent: and the monocotyledons wre the riches of all the plants tested, their average being 22 percent.

Now, jungthe from the percentages of pentosans in their make-up alone, one could assume that the monocotyledons are higher than the dicotyledon in the evolutionary series of plants. Indeed, a family 
tree could be worked out on the bast of the proportions of pentosans in plants: and on such a tree, the plants would appear in the following order (from the highest to the lowest): The Yonocotyledong: In this order rye-straw, oat straw, and corn stover would stand at the top, followed by the careces, Jrancaces, sorghum, red top, and the blue grasses, whlch werve as a link connecting the monocotyledons with dicotyledons that fol10w. Next rould como, then the Dicotrledons: Bere the Composita stand highest. Wh th 12 percent of pentosans: next come the leguminosea (11 percent). the poljgonacsee ( 9 percent), and the solanum ( 8 percent). Intermediate in the arrangement of the dicotyledons rould fall the crucifera. amaranthaceav, portulacaceae, and chenopodiaceae: since only one or two specimens of the fanlles were studied, these groups can be placed only by confecture and approximately. The lower forms of terraneous plants would fall beneath the solanacea on the family tree, and would lead at their lower extremity to the aegae.

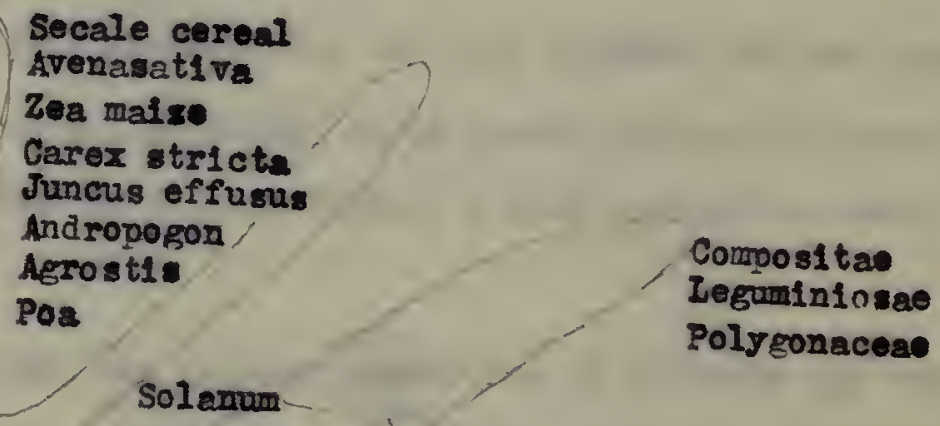

Solenum

Gymospermae

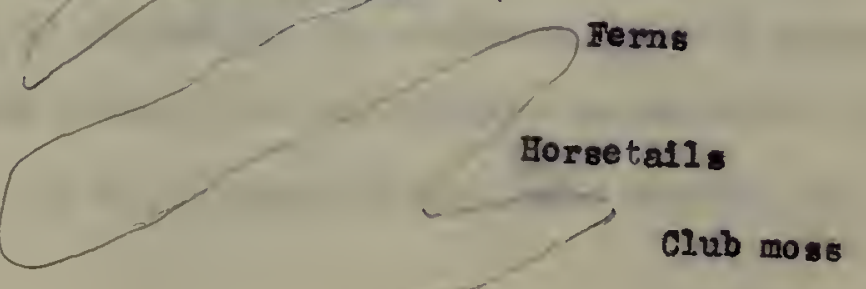

Polytrichum

Tungt 
SUMMART

The revien of the ilterature on decomposition in the soll hes Included studies on the various components of the tissue of plants that serve as sources of energy for organt gms in the voll, and papers on the fortilizing value of reeds.

A partial chemical analysis (Including doterminations of the proportions of nitrogen, carbon. 11 gnin, and pentosans) has been made of 43 different plaute and two seed parts, the majority of which plants are common weeds or widely cultivated crops.

The decompoition of these plants has been studied in the greenhouve in cultures of four different lands: soll whout 11me, soll with 11me, (and for treatments I through 12) sand whout 11 me and sand -1 th 11me. The criteria for the rate of decomposition were the amounts of amonia and nitrates formed.

The plant- tissue incorporated in these cultures for the purposo of the experiment were all collected in as nearly comparable stages of growth as posstble, but were obtalned from a wide varlety of solls and locations.

It wqs found that the arerage proportion of nitrogen was greater in the dicotyledonous than in the monocotyledonous group. ranging in the former from 0.87 percent in the artichoke, to 4.48 percont in parsley, and in the latter from 0.53 percent in rye tren to 2.54 percent In orchard grass. As the nitrogen-carbon rat10 wldened, the content of 
carbon and the pentosan increased, and the rate of decomposition decreased.

This content of pentosans ranged in the dicotyledon from 5 percent in cabbage to 23 percent in tobacco, and in tho monocotyledons from 12 percent in orchard exass to 27 percent in rye straw. As the n1trogenous content decreased, the content of pentosens increased.

The proportion of carbon was hifhest in the monocotylodonous group, ranging from 42 percent in the onlon to 50 percent in witch erass. In the dicotyledonous group it ranged from 36 percent in potato tops to 48 percent in alfalfa. Increasing $w$ th the content of pentosans.

As the proportion of carbon and pentosans content decreased, the rate of decomposition ( 28 shown by the emounts of ammonis and nitrates formed, and by increased plant-growth) increased.

Thire 1s not, apparently, a strict correlation between the rato of decompostion and the total nitrogen content of plant or the nitrogencarbon ratio. Iot the experiment shows rery clearly that on the whole the plants containing most nitrogen decompose more readily than thoze contalning less. The structure of plants and their content of such carbohydrates as 11 ghtn and pextosan (which resist both grinding and decomposition), were al so factors in the rate of decomposition: for plant. of the dicotyledonous group were more easily ground than plants of the monocotyledonous group, and were less resistant to decomposition. If the ratio of nitrogen to carbon is no more than 1 to 25 - 30 the plants decompose easily: but if the rat10 1s wider the incorporation of natural fertilizers in the soll results in a depression of the nitrates. 


\section{BIBLIOGRAPHI}

1. Aso K. and Yoshida R. Promoting the decomposition of organic matter In soils by phosphat1c fert1lizors. Proc. 2nd Int.Cong. So1l Scl.. 3:106. 1932.

2. Bear T.X. So11 Management, p. $45,1924$.

3. Boruff C.S. Buwell A.M. Anaeroble fementation of I1gnin.Journ. Aner. Chern. Soc. 561: 886-889, 1934.

4. Brenchley T.E. The Feeds of arable land in relation to the solls on which they grow. Anr. of Bot. (London( 25: 155-165, 1911.

5. Campbell E.G. Mitrogen content of weeds. Bot. Gaz. 78: 103-115. i924.

6. Clements F.I. * W.J. Shomaltex, The family tree of the slowers. Nat11. L Geographic. vas 1927.

7. Collison R.C. and Conn. 8. J. Iffect of straw on plant growth. N.I. (Geneva) Sta. Tech. Bul. 114, 1925.

8. Conrad H.S. Fossil Plants and Classification and Botanlst 27:95-101-1921.

9. Cooper E.P. Ash constituents of pasture grasses, their standard eleotrode potentials and ecological significance. Plant. Phys. 2:193-214, 19.3.

10. Crulckshank X.M.Report on the seasonal variation in the mineral content $r$ of pastures. Jour. Agric.Sci. 16: 89-97, 1926.

11. Doryland C.J.T. The influence of energy materlal upon the relation of so1l mtero-organt ams to soluble plant food. N.Lal.Hxp.Sta.Bul.116- 1916.

12. Traps G.S. Organic constituents of the soll. Texas Agr.Bup.Sta.Bul. 300 , 1922.

13. O1lbert. B.I. and Pember F.ב. Influence of rye and oat atraws upin the Growth and jteld of certain regetables. Soll Sc1.35: 115-122, 1933. 
14. Greenh111 1. F. and Page H.J. The mineral content of intensively treated pastures and a relationshlp betreen the nitrogen and phosphorus cnntents. Jour. Agr1. Sc1. (England) 21: \#2 p.220-232.233-240. 1931.

15. Harper E.J. The determination of ammonia in solls. Soll Sc1.18: L 409-418. 1924.

16. Dalel H.A. and durphy H.P. The total nitrogen, phos- $L$ phorus and calcium content of comon reeds and native grasses in Oal ahoma. Proc. of the 0kala. Acadeny of Set. 14:37-44, 1934. 17. - Chemical composition of cortain quatic plants. $L$ Bot.Caz. 96: 186-189, 193\%.

18. Heak A.T. A study of the nature of the nitrogenous cornpounds in fung L ous tissue and their decomposition in the 011 . Soll Sc1.27+1-14, 1929.

19. स111. R.R. Decouposition of organle matter in so1ls, Jour.Agri. Res. - f 33: 77-99, 1926.

20. Hepner V.F.E. Fyoming forage plants and their chemical composition. L Wyoming Sta. Fept.1918- p.117, Also Ixp.Sta.Rec. 41-333.

202. Hoagland D.R. Absorption of mineral elements by plants in relation to $L$ so11 problems. Plant Plys 6:373-378.

21. Honcanp F. Handbuch DerPflanzenenernahrung Und Dungerlehre. p.180-220, ᄂ 1931.

2la. \#utchinson C.M. and S. Milligan, Green manuring expertments, Mgr.Res. L Inst. Pur. Bulletin $0-1914$.

22. IIjIn W.S. Composition of the ash components of plants growing in different habitats: Calciphiles. Batan centr. Belheste 50: 95-137. 1932. 23. Ince J.W. Fort1l1ty and weed, N.Dak. Agr. Bxp.Stat.Bul.112, 1915. L 24. Iranoff N.N. and Zwetkoff z.S. The blochemitry of fungt. Blochem Reviow p.521 - 540. 1933. 
25. Jensen C.A. Lefect of decomposing organic matter on the solubilw

Ity of certain Inorganic constituents of the soil. Jour. Agr.Res.

918 p.253-268, 1917 .

26. Jensen H.I. On the influence of carbon nitrogen ratios of organle material on the mineralization of nitrogen. Jour. Afrlc.st. 19: 71-82. 1929.

27. King. M. Uber die Chemische sumensetzung einigar Unlcrauter sowle deren Fert als Hutter and Dugenmittell Landw. Vers. Stat.85: 433-470, 1914. C1ted from the rork of Harper H.J.

28. Iyon T.I. and Buchman H.O. The nature and propert1es of solIs, 1926 p. $99-126$.

29. Meschaupt J.G. Verslag Iandbouwk. Onderzoek. RIJkslandbouwproefstat (Netherlands) 22:25, 144, 1918. Also Exp.Sta.Rec.41-422.

30. Nartin T.I. Influence of chenical composition of organic matter on rate of decomposition. Jour. Am. Soc. aspi.25: 3'1-346. 1933.

31. The effect of clover and alfalfa on fungl. Soll

Sc1. 27: 399-406. 1929.

32. Hehta M.M. Blochemical and histological studies on Ilquefaction.

Part I the nature of $11 \mathrm{gnin}$. its phrslologlcal significauce and $1 \mathrm{ts}$ estimation in timbers. Blochem.Journal 19: 958-978. 1925.

33. M111 spaugh C.F. Feeds as fert111zers. M.Va.Agx.Ixp.Sta.Bul. 19. 1891. 33a.M1tchell J.H. A tudy of the relat1onship between the mineral content of the so11 and plants erorm on the so11. Sc.Sta.Report 1931 p.106. 34. The effect of straw on biological soll Processes.

So11 Sc.12: 233-259, 1921.

35. Melier J.R. Studies on the correlation between the production of carbon dioxide and the accumalation of amoonla by soll organtams. So11 Sc1.5: 225-242, 1918. 
36. Werton G.A and Daniloff I.B. The influence of mamre and organle residues on plant growth. So1l Sc1.24: 95-99, 1927.

37. Woman A.G. The nature of the residual homicelluloses of rotted atraw. B10chen. Journ.26: 573-577. 1932.

38. n:r J.3. Minerals in pastures. 1921.

$\sqrt{39 a .0 f f 1 c i a l}$ Methods of the Assoclation of officlal Agrlcultiral Chemists. 2nd edition.

39. Patrick 1.L. Influence of crop residue decuy on soll ax retes. Soll L Scl. $35: 335-354,1933$.

40. F1cke1I J.1. Lnalysis of some Forta weeds and grasses. Mla. AgP. Exp. Sta.BuI.11, 1890 .

41. Pool R.d. Forers and flowering plants. 1929 p.157-169.

42. Ranker t.R. Dotermination of totel nitrogen in plants and plant solutions: A comparison of methods with modlfications. Annale of the Ho. Botanical Garden. 12: 367-380, 1925.

43. Rege R.D. Blochemical decompostion of cellulosic materials. Annals of Applled B101. 14: 1-45, 1927.

$\sqrt{ }$ 44. Robinson m.0. Steinkoning I.A and MIIIer C.F. The relation of some of the rarer elemente in golls and in plants. U.S.D.A. Bur. of Solls Br21.

45. Fudolf $G$. The Importance of soll algae. Irnahr Fflanze 30: 413-414, $193^{\text {I. }}$

47. Pussell E.J. Soll condltions and plant Grorth. 6 th Edition 1933. p. 312.

48. Salter R.M. and Creen T.C. Jactors affecting the accumulation and loss of nitrogen and organic carbon in cropped solls. Jowr. Am. Soc.Agrt.25: 622-630, 1933. 
49. Schm1dt E.G. Peterson \%.H. and Fred E.B. The destruction of pentosane by molds and other microorganism. Soll Sc1.15: 479-488, 1923.

50. Schreiner O. and Fallyer G.B. Colorimetric turbidity and titration methods used in so11s and investigations U.S.D.A.Bur. of So1Is Bul. 31. 1906.

51. S horey B.C. and Sk1nner J.J.Cheralcal nature of soll organ1c matter. U.S.D.A.Bur. of Solls Bul.74, 1910. 52. organtic compounds and fertilizer action. U.S.D.A.

Bur. of Solls Bul.77, 1911.

53. Hitrogenous soll constituents and their bearing on so11 fert111ty. U.S.D.A. Bur.of So11s Bul. \$87, 1912.

54. Scott H. Influence of wheat straw on the accumulation of nitrates in $V$ so118. Jour.Am. Soc.Agr1. 13: 233-258, 1921.

55. Shunk I.V. Microblologlcal activities in the solls of an upland bog In North Carolina. So11 Sc.27: 283-303. 1929.

56. Smolik I. Bumas from alfalfa.Vetsnik Ceskoslov. Akad. Zemedelske 10: 14-17, 1934. In Chemc Abst.28 $\neq 20$, p. 6506, $193^{4}$.

57. Snyder H. Forage crops of high and Iow proteln conten. Minn. Afx. Ixp. Sta.Bul. 101, 1907.

58. Stutger A. and Seldler L. The content of Important plant food ingredients In some common reeds. Fuhlige Landw. 2tg. 57: 429-430, 1908, Also. Bx. Sta.Rec. 20: 750, 1909.

59. Thow C. and Smith N.R The relation of soll acidity to the decompostion $V V$ of organlc residues. Jour.Am.Soc.Agr. 25: 392-396, 1933.

60. 71 ityon J.A. and Fred E.B. The effect of different linds of wood and $V$ wood palp cellulose on plant growth. Jour.Am.Soc.Agr.17: 199-208. 1924. 61. Tenny F.G. and Waksman S.A. Composition of natural organic materials and their decomposition. IV. The nature and rapidity of decomposition 
of the various organic complexes in difforent plant material s under aeroble conditions. Soll Sc1.28-55-84, 1929.

62. Wakmen S.A. and Tenny J.G. Composition of natural organic materials and their decomposition in the soll. III The influence of the nature of the plant upon the rapidity of 1ts decomposition. Soll Sc1.26:15517. 1928.

63. The origin and nature of soll organic matter or so11 "hums". III The nature of the substances contributing to the formation of "huras". So11 Sc1.22:323-333. 1926.

64. The orfgin and mature of soll organic matter or so11 "huma". IV. Decomposition of various ingredients in straw, alfalfe meal. by mixed cultures and by pure cultures. Soll Sc1.22:395-406, 1926.

65. and Teany F.C. The cormosition of natural organic materials and their decomposition in the soil. II. Influence of ago of plant upon the rapidsty and n-ture of 1 ts decomposition - Rye plants. So11 Sc1.24: 317-333, 1927

66. Thiting A.I. and Schoonover F.R. Comparative rate of decomposition of green and cured clover tops in so1ls. So11 Sc1.9: 137-149, 1920. $6 థ a$. and Richmond. The relative sate of nitrification of different parts of the sweet clover plant. Soll Sc1. 24:31-37. 1927. 67. $\$ 11$ son B.J. and $\$ 11$ son J.K. An explanation for the relative effects of timothy and clover residue in the soll on nitrate depression. CornelI Memolr 95. 1925.

68. Wolfe E.Ashchen Analysen. 1871 


\section{ZIST OF FIOURES IN APPEINDIX}

Flgure I. Weekly fluctuations in ppm. of amonie and il trate nitrogen prodiced in solls $w$ th and whout ilme from 41 grame of nitrogen from Leguminoseae Ilsted.

Flgure II. Feekly Iuctuationg in p.p.m. of ammonla and nitrate nitrogen producod in so11 from .41 grams of nitrogen from Solanoceae shom.

Flgure III. Same as Figure II except the equivalent of 2 tons of 11 me per acre adred.

Figure IV. Feekly Iluctuations in p.p.m. of ammonia and altrate nitrogen produced in 3011 from the additoon of .41 gxams of nitrogen from Gramineav 11sted.

Mgure V. Teekly iluetuations in p.p.m. of axmonia and nitrate nitrogen produced in soll from .41 grams of nitrogen from Compositae 11 eted.

F1gure VI. Sqmo as Fyre $V$ except from Polygonaceas 118ted.

F1gure VI. Same as $\nabla$ except from 211 other plantg representing different familss. 
TABCE I - Parts per million of amonia and nitrate nitrogen produced in soll with and without l1me ilgo the correspondIng percentage molsture for these determination are listed.

Nitrogen as p.p.t. of $\mathrm{NB}_{3} \& \mathrm{NO}_{3} \mathrm{Alfalla}$ as check.

Molsture as of Dryit.

1. Sudan Grass

2. German millet

3. Oat strar

4. Pye stren

5. Mimothy

6. Corn stover

7. Red clover

8. Alfalfa

9. Bucksheat hulls

10. Cottonseed hul?s

11. So r ghrum

12. Tobacco

13. Fungt

14. Seameed

15. club moss

16. Horsetais

17. Ferm

18. Butter cup

19. Bucknbeat

20. Inotwee?

21. inartweed

22. Penper ton

23. Potato tops

24. Tometn tops

25. Art1 chole

26. Bidens

27. Ragneed

28. Tantalum

29. Pursl ey

30. Amaranth

32. Cabbage

32.001 on

33. Orchard grass

34. Lambe quarter

35. Xentucky Blue gra

36. Turnip top

37. Canadian Blue grem

38. Sweet clover

40.Juncus of fusus - $\quad-18$

41. Moss(hairs cap) 219

42. Carer tricta

43. 11 tch grass

44. Gladiolus

45. Red top
$-19$

218

$-21$

So11 Soll \&IINE: OSO11

\# $\mathrm{H}_{2} \mathrm{O}$ \# $\mathrm{H}_{2} \mathrm{O}: \mathrm{N} \mathrm{B}_{2} \mathrm{O}$

1322

2518

$-18$

- 19

T 22

- 25

3320

61
$-\quad 17$

- 20

- 31

$77 \quad 19$

234

233

226

229

226

233

$3 \quad 32$

5625

229

121

131

$\begin{array}{lll}9 & 52 & 29\end{array}$

423
-425

223

127

- 23

- 24

- 24

$11 \quad 26$

- 27

- 22

$\begin{array}{ll}33 & 27 \\ 31 & 25\end{array}$

122

3
1525

$21 \quad 22$

4920

2619

2420

1520

1921

1819

$-19$
:17 21

2919

127
-25

120

227

2621

8123

$-21$

222

- 33

9724

6321

6217

226

325

23

320

219

8017

422

2621

5522

4920

123

2920

3017

5320
10120

8920

8319

4018

1421

$98 \quad 23$

$36 \quad 24$

2820

3219

2822

321

521

3522

322

321

324

118
14 deys

Sol1 \& Iime: Soll

N $\mathrm{H}_{2} \mathrm{O}$

4

23

1625

2

19

17

324

128

426

100

123

- 20

130

8119

$\begin{array}{rr}6 & 25 \\ 33 & 27\end{array}$

$12 \quad 26$

$13 \quad 28$

223

222

3

25.

17 .

430

322

$46 \quad 24$

$53 \quad 24$

127

$\begin{array}{rr}2 & 25 \\ 20 & 24\end{array}$

$31 \quad 23$
$:$ स्त

:31 23

6522

- 28

227

- 24

- 29

222

11825

324

124

132

23924

424

6023

331

1930

230

1126

224

6121

1426

9024

6329

7625

- 29

3524

5122

4024

10124

9023

8026

4922

1427

7729

4230

2326

2926

3827

227

326

3627

129

$-26$

129

- 26
21 days Soll \& IIme

I $\mathbb{I}_{2} \mathrm{O}$

$10 \quad 25$

$36 \quad 26$

$\begin{array}{ll}6 & 25 \\ 2 & 28\end{array}$

$6 \quad 27$

332

$23 \quad 29$

$50 \quad 24$

- 25

722

8833

$88 \quad 25$

4421

$2 \quad 22$

$3 \quad 14$

$\begin{array}{ll}3 & 17 \\ 3 & 19\end{array}$

$38 \quad 19$

$26 \quad 22$

$\begin{array}{ll}63 & 19 \\ 63 & 18\end{array}$

323

21 18

$26 \quad 17$

5. 17 


\section{APPINDIX I}

TABLE I - Parts per million of ammonia and nitrate nitrogen pro-

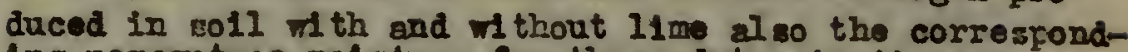
ing percentage molsture for the se determinations are 11 sted.

Nitrogen as p.p.m.of $\mathrm{NB}_{3}$ \& $\mathrm{NO}_{3}$ Alfelfa as check Mo1sture es of Dry

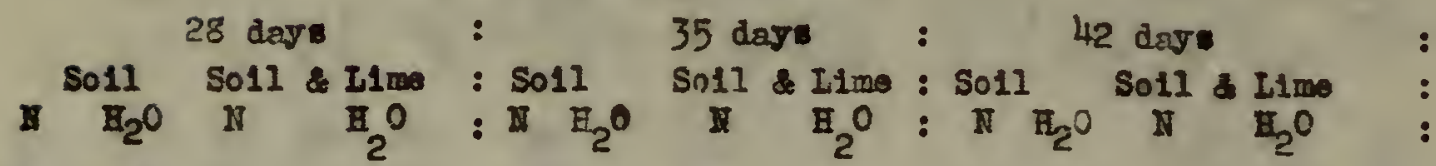

1. $23 \quad 24$

3. 125

4. - 22

5. -23

7. $8 \overline{4} 25$

8. 11522

9. $=25$

11. - 33

12.137 22

13. 818

14. $61 \quad 16$

15. $\frac{1}{5} 2$

16. 26

17. 4

18. 18

19. 5 ?

21. 22

22. 51

23. 72

24. 70

25. 2

26. 46

27. 44

28. 63

29. 85

30. 87

31. 79

32. 56

33. 22

34.106

35. 50

36.33

37.43

38. 47

39. 4

41. 38

42. -

43. 2

44.3
$44 \quad 24$

4420

1122

720

$\begin{array}{rr}3 & 2 \\ 12 & 2 \\ 12 & 21\end{array}$

19 2.

$\begin{array}{lll}78 & 21 & 82\end{array}$

$\begin{array}{llll}2 & 23 & -18 \\ - & 20 & 1 & 18\end{array}$

$\begin{array}{rrrr}2 & 33 & 1 & 24 \\ 123 & 23 & 100 & 18\end{array}$

$\begin{array}{llll}4 & 23 & 7 & 31\end{array}$

$\begin{array}{rrrr}65 & 17 & 49 & 31 \\ 1 & 27 & 2 & 34\end{array}$

$\begin{array}{llll}25 & 24 & 1 & 26 \\ 12 & 22 & 2 & 36\end{array}$

$\begin{array}{llll}38 & 24 & 2 & 33\end{array}$

$\begin{array}{llll}16 & 23 & 3 & 33 \\ 48 & 22 & 42 & 24\end{array}$

$38 \quad 21-31$

4918

$86 \quad 23$

$84 \quad 18$

$2 \geqslant 0$

4220

6117

$\begin{array}{ll}56 & 20\end{array}$

9023

9123

$83 \quad 28$

5126

$33 \quad 27$

9528

6126

4126

6225

$\begin{array}{ll}46 & 27\end{array}$

227

- 29

$40 \quad 28$

128

329

$\begin{array}{ll}3 & 27 \\ 2 & 30\end{array}$ $\begin{array}{ll}57 & 21 \\ 18 & 18\end{array}$

$15 \quad 24$

$19-21$

$19-22$

$\begin{array}{lll}21 & 28 & 23 \\ 19 & 92 & 19\end{array}$

$23 \quad 141 \quad 20$

$18-21$

- 22

$-28$

21322

- $25 \quad 5 \quad 29$

$\begin{array}{llll}89 & 17 & 83 & 26\end{array}$

$\begin{array}{llll}47 & 27 & 4 & 23 \\ 16 & 21 & 2 & 29\end{array}$

$\begin{array}{llll}31 & 27 & 26 & 26\end{array}$

$\begin{array}{llll}22 & 26 & 3 & 28\end{array}$

$\begin{array}{llll}74 & 17 & 49 & 27\end{array}$

$\begin{array}{llll}35 & 19 & 2 & 24\end{array}$

$\begin{array}{llll}50 & 17 & 54 & 22\end{array}$

$\begin{array}{llllll}81 & 28 & 127 & 22 & 98 & 24\end{array}$

$\begin{array}{lllll}86 & 29 & 94 & 19 & 97 \\ 4 & 42\end{array}$

$\begin{array}{lllll}4 & 4 & 25 & 1 & 23\end{array}$

$\begin{array}{lllll}23 & 56 & 21 & 47 & 19\end{array}$

$\begin{array}{llllll}33 & 25 & 56 & 17 & 68 & 20\end{array}$

$\begin{array}{llll}86 & 21 & 79 & 27\end{array}$

7923

$\begin{array}{ll}96 & 31 \\ 80 & 24\end{array}$

$49 \quad 22$

$30 \quad 23$

9125

$70 \quad 25$

$\begin{array}{ll}40 & 25 \\ 59 & 27\end{array}$

$59 \quad 27$

$\begin{array}{ll}2 & 33 \\ 2 & 31\end{array}$

4128

$2 \quad 24$

$\begin{array}{ll}- & 23 \\ 4 & 23 \\ 3 & 28\end{array}$ 


\section{APPENDIX 1}

TABLE I - Parts per million of amonia and nitrate nitrogen pro(cont.3) duced in soli with and without lime also the corresponaing percentage molsture for these determinations are ilsted.

Nitrogen as p.p.m. of $\mathrm{NH}_{3}$ \& $\mathrm{NO}_{3}$ Mfalfa as check Molsture as of Dry Vt.

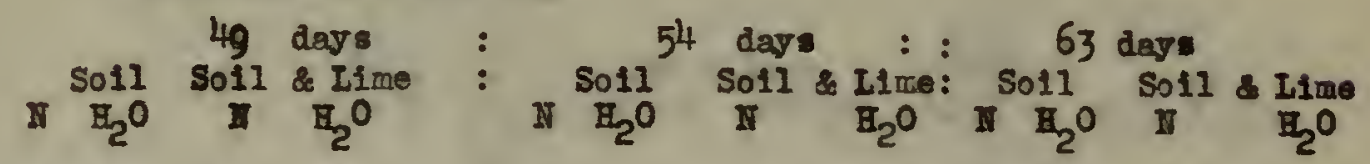

1. $\quad 37 \quad 20 \quad 44 \quad 19$

2. $\quad 70 \quad 18 \quad 46 \quad 18$

3. $\quad 922 \quad 3 \quad 21$

$\begin{array}{lllll}4 . & 21 & 3 & 21 \\ 5 . & 8 & 22 & 3 & 17\end{array}$

6. 222 9 19

7. $6519 \quad 4 \quad 15$

$\begin{array}{lllll}8 . & 78 & 19 & 78 & 16\end{array}$

9. $\quad-20316$

10. - $20 \quad 2 \quad 19$

11. $227 \quad 123$

$\begin{array}{lllll}\text { 12. } & 117 & 18 & 77 & 17 \\ \text { 13. } & 5 & 25 & \frac{1}{3} & 28\end{array}$

14. $\quad 88 \quad 17 \quad 88 \quad 24$

15. $522 \quad 3 \quad 26$

16. $45 \quad 24 \quad 24 \quad 24$

17. $18 \quad 20 \quad 2 \quad 28$

18. $\begin{array}{llll}48 & 24 & 32 & 21\end{array}$

19. $\quad \begin{array}{llll}23 & 25 & 17 & 27\end{array}$

21. $4917 \quad 34 \quad 29$

22. 76 IE $57 \quad 19$

23. $143 \quad 22 \quad 145 \quad 20$

24. $9918 \quad 133 \quad 17$

$\begin{array}{lllll}25 . & 5 & 24 & 2 & 25 \\ 26 . & 86 & 17 & 49 & 17\end{array}$

27. $\quad 65 \quad 16 \quad 68 \quad 22$

28. $10319 \quad 56 \quad 18$

29. 13818

30. $\quad 12920$

32. $86 \quad 21$

33. 4121

34. $\quad 134 \quad 22$

35. $46 \quad 23$

36. $\quad 54 \quad 25$

37. $\quad 7521$

38. $\quad 10120$

39. $\quad-21$

40. 121

41. $53 \quad 22$

42. - 21

43. $\quad 2 \quad 26$

44. 1224

45. $\begin{array}{llll}37 & 27 & 27 & 16\end{array}$

$\begin{array}{llll}47 & 25 & 67 & 22\end{array}$

$\begin{array}{llll}24 & 27 & 3 & 24\end{array}$

$\begin{array}{llll}1 & 25 & 2 & 26\end{array}$

$\begin{array}{llll}13 & 24 & 2 & 24\end{array}$

$\begin{array}{llll}34 & 25 & 16 & 30 \\ 61 & 22 & 49 & 24\end{array}$

$\begin{array}{llll}60 & 22 & 76 & 17\end{array}$

$\begin{array}{llll}1 & 23 & 3 & 19 \\ -23 & 2 & 21\end{array}$

56 days

11313

29

$\begin{array}{lll}97 & 24 & 124\end{array}$

$\begin{array}{lll}18 & 34 & 1\end{array}$

$\begin{array}{lll}51 & 28 & 25 \\ 21 & 21 & 1\end{array}$

25

$\begin{array}{rrr}2 & 25 & 2 \\ 85 & 21 & 125\end{array}$

25
17

$\begin{array}{llll}21 & 21 & 1 & 32\end{array}$

$\begin{array}{llll}43 & 24 & 42 & 24\end{array}$

$37 \quad 25 \quad 20 \quad 28$

$\begin{array}{llll}62 & 17 & 59 & 22\end{array}$

$\begin{array}{llll}61 & 21 & 52 & 27\end{array}$

88 21. 82 2?

$\begin{array}{llll}136 & 30 & 151 & 31\end{array}$

$\begin{array}{rrrr}106 & 27 & 1 & 27 \\ 18 & 54 & 18\end{array}$

$\begin{array}{llll}63 & 17 & 63 & 26\end{array}$

$\begin{array}{llll}108 & 19 & 59 & 19\end{array}$

$\begin{array}{rr}93 & 24 \\ 109 & 25\end{array}$

$\begin{array}{ll}79 & 18\end{array}$

6221

11020

8221

$\begin{array}{ll}71 & 22\end{array}$

$\begin{array}{ll}66 & 23\end{array}$

8723

$10 \quad 22$

120

5121

- 22

1320

$\begin{array}{rr}13 & 24 \\ 4 & 23\end{array}$ 


\section{APPINDIX I}

TABLE I - Parts per million of ammonia and nitrate nitrogen pro(cont.4) auced In soll 1 th and without Ilme also the corresponding percentage molsture for these determinations are 1isted. Hitrogen as p.p.m. of $\mathrm{NH}_{3}$ \& $\mathrm{NO}_{3}$ Alfalla as check. Molsture as of Dry $\mathrm{Wt}$.

1. Sudan grass

2. German millot

3. Oat stram

4. Iave stram

5. Timothy

6. Corn stover

7. Red clover

8. Nleara

9. Buclawheat "hulds

10. Cottonseed halls

11. Sorghum

12. Tobacco

13. Tung1

14. Seareed

15. Club moss

16. Horeetalls

17. Fern

18. But tercup

19. Buckrheat

20. Kno tweed

21. Smartweel

22. Pepper top

23. Potato tops

24 . Tomato tope

25. Arti choke

25. Bldons

27. Pagresd

28. Ianthium

29. Pursloy

30. Amaranth

31. Cabbago

32. Onion

33. Orchiprd grass

34. Iambs quarter

35. Kentucly blue grass

36. Turnip top

37. Canarian blue grass

38. Swe clover

39. Carax lupulinus

40. Juncu's effusus

H. HoEs (hatrs cap)

42. Carex tricta

43. 11 tch grass

44. Gladiolus

45. Red top

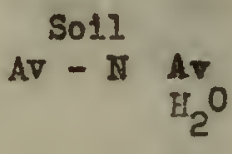

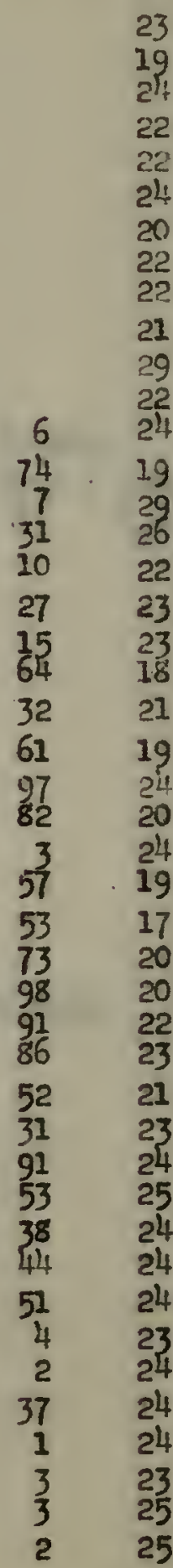

3

19

22

22

24

20

22

21

29

22

19

29

22

23

23

21

19

24
19

$$
\text { Soll Lime check check }
$$
Av. $-\mathrm{II}$ Av $\mathrm{B}_{2} \mathrm{O}$ Soll SolI \& fino

(9) 37

$20 \quad 83$

31

41

50

$\begin{array}{ll}22 & 3 \\ 23 & 5 \\ 22 & 1 \\ 24 & \\ 22 & \\ 27 & 1 \\ 24 & 5 \\ 20 & 10 \\ 21 & \\ 20 & \\ 27 & \\ 20 & 14 \\ 28 & 10\end{array}$

$25 \quad 91$

2781

24

27

24

26

23

28

23

25

23
29
21

24

22

67

63
58

30

27

12
7

7
$39 \quad 24$

$55 \quad 50$

28

544

$52 \quad 31$

$100 \quad 100$

23

14

1

$149 \quad 118$

$91 \quad 83$

79

70

35

34

107

99

57

53

100

58

42

48

56

4

40

1

4 
TABt II - Parta por al111 on of axworia and nltrato altrogen produced in and 1 th and 1 thout $11 \mathrm{me}$ al so the parallel mol ctures for those doterminations.

Jitrogen o p.p.w. of $\mathrm{sk}_{3}+2.83$

voleture on percentage of ary wt.

7 dars

Sand sasd in

1. Sodan crase

2. Germen alilet

5. Tinotho

6. Cosn stover

7. Red clover

8. Alealea

9. Buckinuse bul 11

10. Cottonueed thall:- 7

12. Tobacco

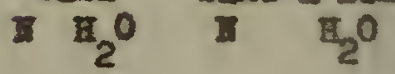

3. Oat otran

4. Rove straw

11. Soretrom

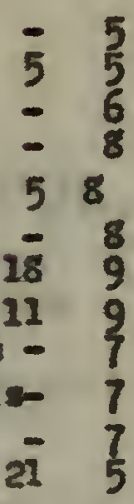

5
$5 \quad 5$
$-\quad 6$

58

$-8$

9
14 days Sand घ $\mathrm{E}_{2} \mathrm{O}$

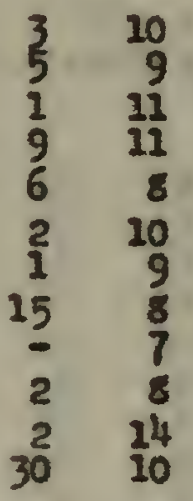

28 daye

21 day:

Sand Sand of II

I $\mathrm{H}_{2} \mathrm{O}$

2. Suden gases $\frac{1}{4}$ ?

3. Dat strat 111

4. Doe straw

116

5. Tinotly

112

110

7. Red clover

111

8. Mlatea

289

9. Buclahoat hal I: 113

10. Cottonneed hull 113

11. Sorghu

112

12. Tobacco

$48 \div 9$

1. Sudan Ease 48

3. Oat otsac

4. Pye otra

5. Timotho

27

6. Corn tover

17

7. Bed elover

8. Aralfa

$-5$

86

9. Buckmats bull - 5

10. Cottonaced " -

11. Sorgin

12. Tobacco

$40 \begin{array}{rr}12 \\ 5\end{array}$
42 dago

\section{ह 20}

299
49
-10
$=11$
$=11$
$=10$
$=11$
199
$=98$
-118
2511

67

49 days

Sand Find \& Ifwe Sand Sand a IImo

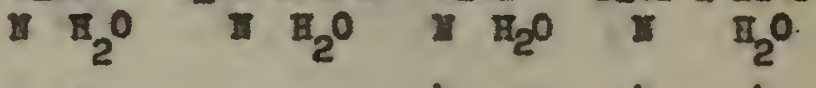

$-9$

$-11$

120

28

238

110

- 10

$40^{2} 15$
35 das:

$\begin{array}{rrrr}4 & 10 & 4 & 4 \\ 8 & 7 & 5 & 5\end{array}$

394

$\begin{array}{lr}3 & 12 \\ 4 & 9\end{array}$

$\begin{array}{ll}4 & 9 \\ 4 & 10\end{array}$

$\begin{array}{lrl}4 & 10 & 8\end{array}$

2978

$316=11$

$678=4$

63 das:

$\begin{array}{rrrrrr}2 & 8 & 5 & 11 & 2 & 12 \\ 5 & 6 & 7 & 11 & 3 & 9 \\ 3 & 8 & 1 & 14 & 1 & 12 \\ 2 & 9 & 2 & 15 & 1 & 18 \\ 2 & 9 & 1 & 10 & 2 & 15 \\ 2 & 7 & 1 & 12 & - & 17 \\ 3 & 5 & 9 & 9 & 2 & 7 \\ 4 & 5 & 42 & 10 & 1 & 7 \\ 2 & 6 & 2 & 11 & - & 11 \\ 2 & 13 & - & 11 & 2 & 12 \\ 1 & 11 & 2 & 22 & 2 & 14 \\ 3 & 4 & 35 & 10 & 1 & 10\end{array}$
381
19 das:

Sand ${ }_{\text {II }} \mathrm{O}$

$\begin{array}{rr}6 & 8 \\ 1 & 6 \\ 3 & 8 \\ 2 & 10 \\ 1 & 8 \\ 2 & 7 \\ 2 & 6 \\ 6 & 7 \\ 1 & 9 \\ 1 & 7 \\ 2 & 10 \\ 3 & 5\end{array}$ 
TABLI II - Parta per mill1on of amonla and nitrate nitrogan (Cont.2) produced in sand $w 1$ th and without IIme also tho parallel molatures for those determinations.

Nitrogen as p.p.m. of $\mathrm{Mg}_{3} \& \mathrm{NO}_{3}$

Molisture on percentage of dry $3 t$.

1. Sudan grass

2. German millet

3. Dat stran

4. Rye stren

5. Timo thy

6. Corn stover

7. Red clover

8. Alfalra

9. Buckwheat halls 10. Cottonseed halls

Sand

AT. $\%$ or $A$

p.p.m. control $\mathrm{K}_{2} \mathrm{O}$

11. Sorghum

12. Tobacco

$\begin{array}{rrr}4 & 16 & 8 \\ 6 & 25 & 7 \\ 2 & 7 & 9 \\ 3 & 14 & 11 \\ 3 & 13 & 10 \\ 1 & 6 & 10 \\ 7 & 29 & 6 \\ 23 & 100 & 6 \\ 1 & 6 & 8 \\ 2 & 7 & 10 \\ 3 & 14 & 12 \\ 38 & 166 & 6\end{array}$

Sand \& Ime

A7. $\quad$ of

p.p.m. control

I.

$\begin{array}{ll}4 & 74 \\ 4 & 77\end{array}$

$3 \quad 58$

129

131

122

252

$4 \quad 100$

127

122

$\begin{array}{ll}1 & 24 \\ 2 & 37\end{array}$ 

plant source 11sted.

So11

Chect:

1. Sod in grase

2. Geraes miliet

3. Oat etraw

4. Iye atraw

V5. Fimothey

6. Corn stover

7. Red clover

8. Alfalfa

9. Buchuteat bull.

20. Cottonseed hulla

11. Sor foren

12. Tobacco

13. Pungt

14. Suanned

15. Club nos:

16. For sotalle

17. Tैera

18. Buttercup

19. Bucknateat

20. Inotraed

21. Snartweed.

22. Pepper

23. Fotato tops

24. Tomato

25. Asticholc

26. 31 dens

27. Premoed

28. Tanthium

29. Purviluy

30. Rmarantb

31. Cabbage

32.0 . 10 a

33.0rehard cres

34. Lambe guartor

35. Bentuder blue

36. Tumip top

37. Canadian blue gamis:5

38. 5 wot clover

39. Carex Iupulinus

40. Jrmers efrusta

41. Hos: (hatrs cap)

42. Carex stricta

43. 1 tch grass

4P. Cladiol1

45. Red top
15.5

17.0

18.0

17.0

21.0

Plant:

26.0

27.5

22.5

20.5

25.0

32.0

26.5

27.0

25.0

25.5

18.0

17.0

16.5

17.5

18.5

17.5

18.5

11.5

18.0

17.0

13.5

16.5

17.5

18.5

16.0

16.5

19.0

18.5

17.0

16.0

15.5

30.0

18.0
Av.dry

vt.

15. 62

2.56

1.51

1.44

2.13

3.38

9.01

1.48

1.93

12.37
0.62

5.99

1.73

3.03

1.37

3.05

1.52

5.64

2.86

5.02

6.13

6.145

0.76

4.85

5.31

5.77

8.77

9.35

9.25

7.61

6.10

5.26

7.11

6.68

8.58

6.23

3.70

1.15

5.36

2.10

1.27

1.37

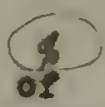

Control

$100 \%$

16.46

30.19

9.74

9.28

13.69

8.77

21.11

58.08

9.53

12.41

8.34

79.90

87.00

24.0

4.1

19.9

22.0

82.0

41.50

73.0

88.9

93.6

11.0

70.4

77.0

83.7

57.0

61.55

60.90

49.93

16.03

31.51

45.65

43.83

54.99

40.88

$2 \% .28$

7.55

35.17

1.3 .78

8.33

8. 99 
TABLE III - Grans of dry wolght of barley produced in 8011 with and without 1ime from .41 gram of nitrogen from the plant source listed.

Cheak

1. Sudan grass

2. German millet

3. Ogt tran

4. Fỹe straw

5. Timothy

6. corn stover

7. Red clover

8. Alfalfa

9. Buckwheat hull.

10. Cottonseed hull.

11. Sorghum

12. Tobacco

13. Wungl

14. Seameod

15. Club moss

16. Eorsetalls

17. Ferm

18. Buttercup

19. Buckmheat

20. Knotweed

21. Smartweed

22.Pepper

23. Potato tops

24. Toma to

25. Artichoko

26. Bidens

28. Ragweed

28. Kanthium

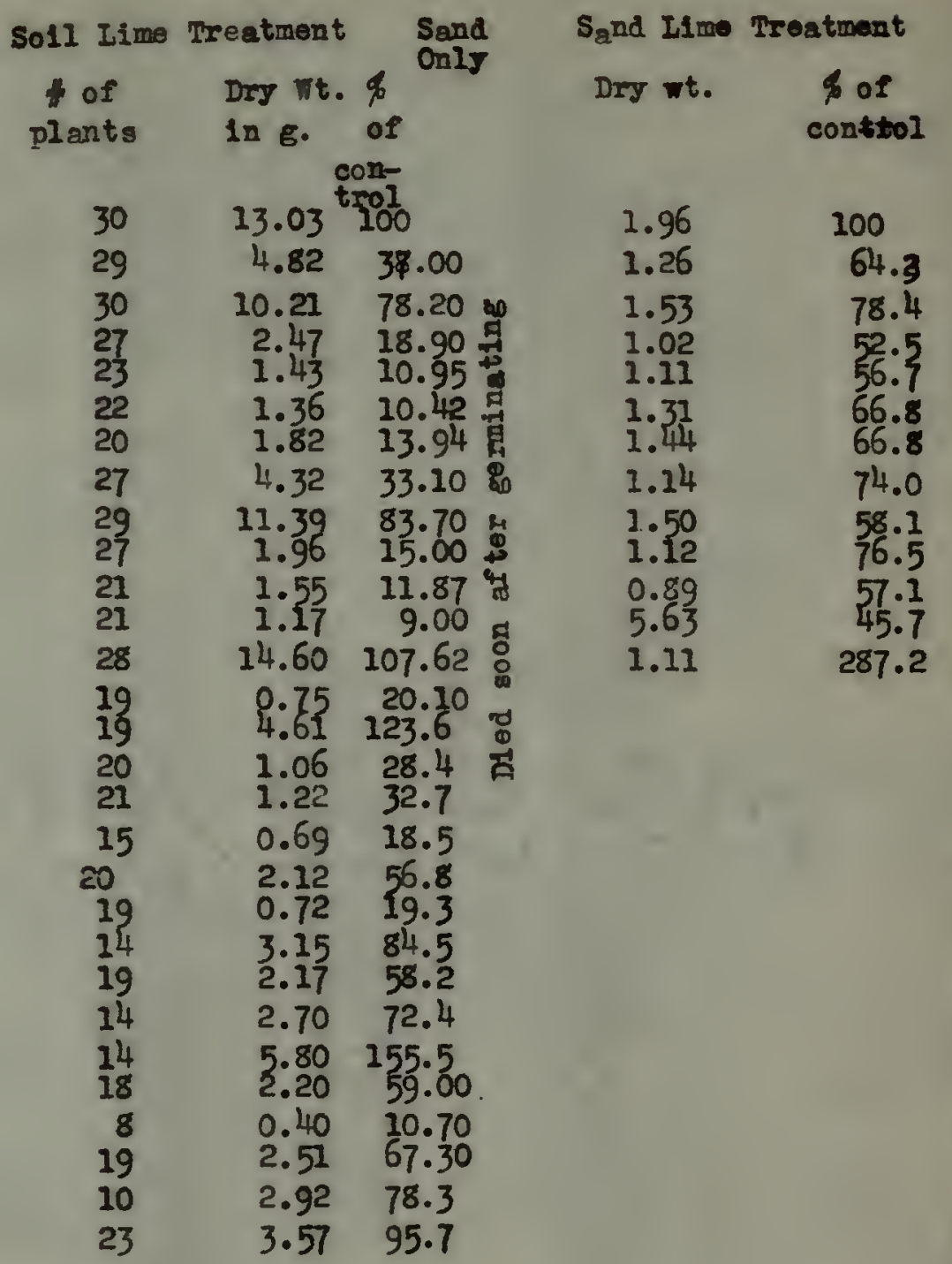



Fig. II

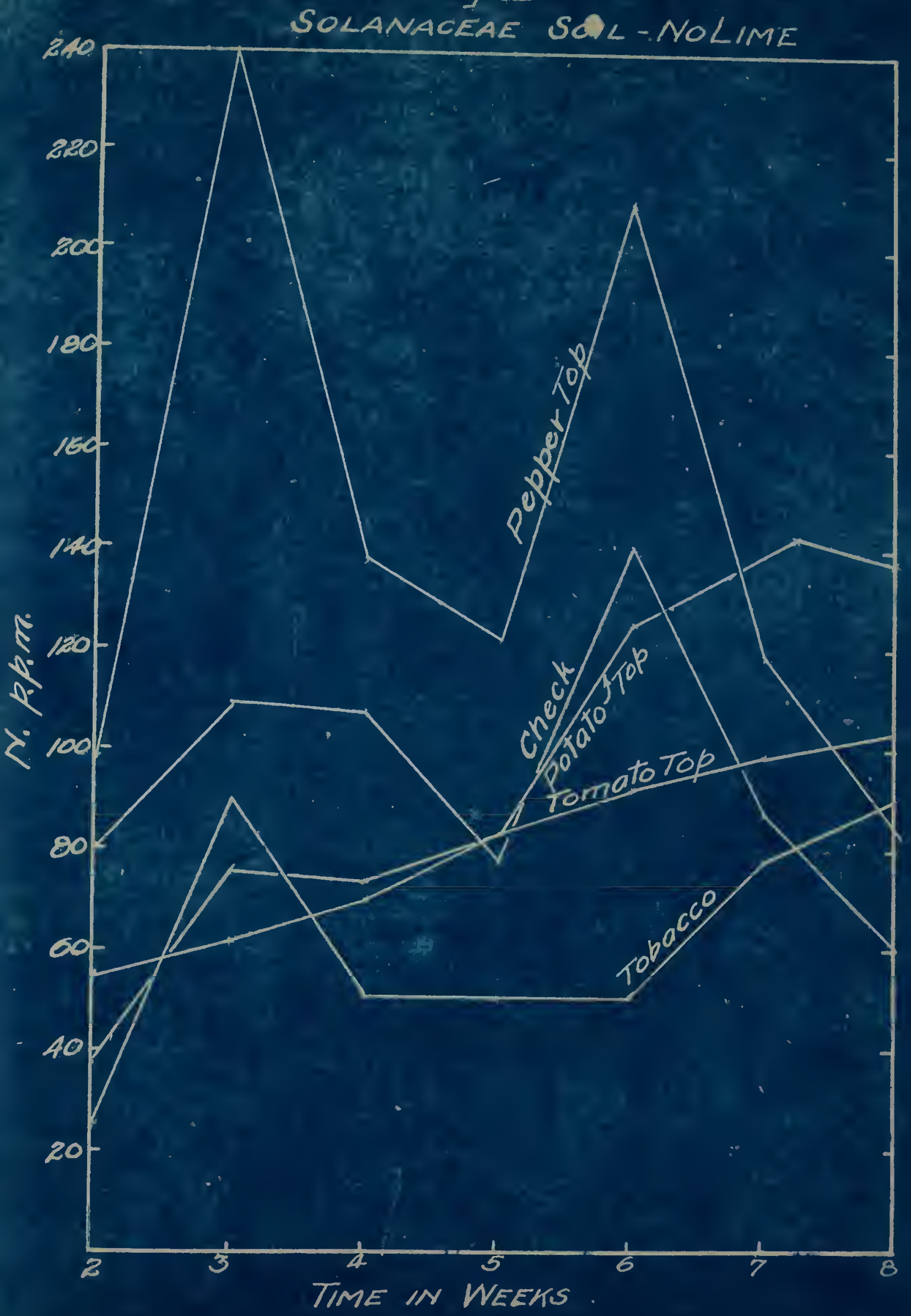


Fig.III

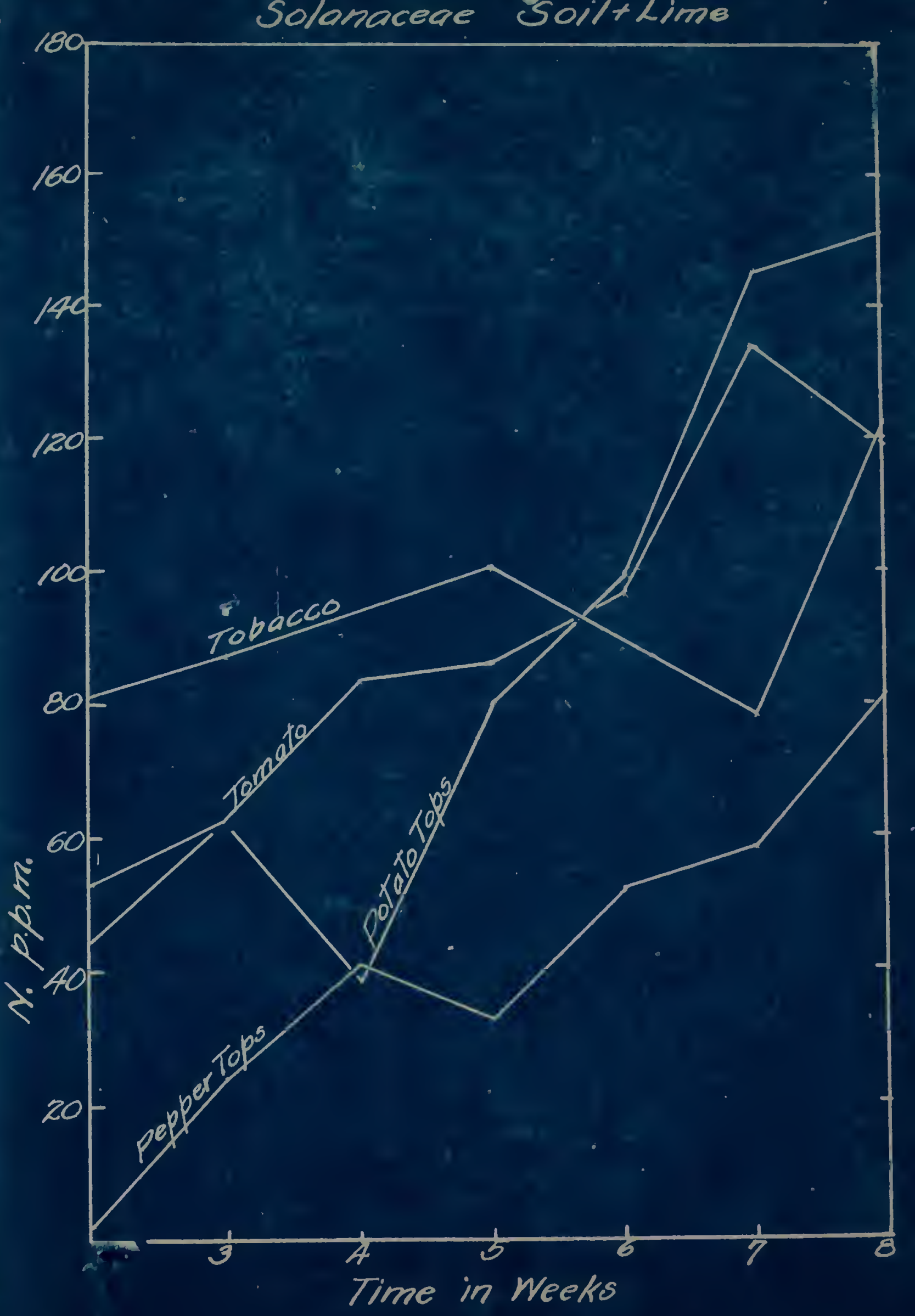




$$
\begin{aligned}
& \text { Fig. IV } \\
& \text { Gramineae Soil-nolime }
\end{aligned}
$$

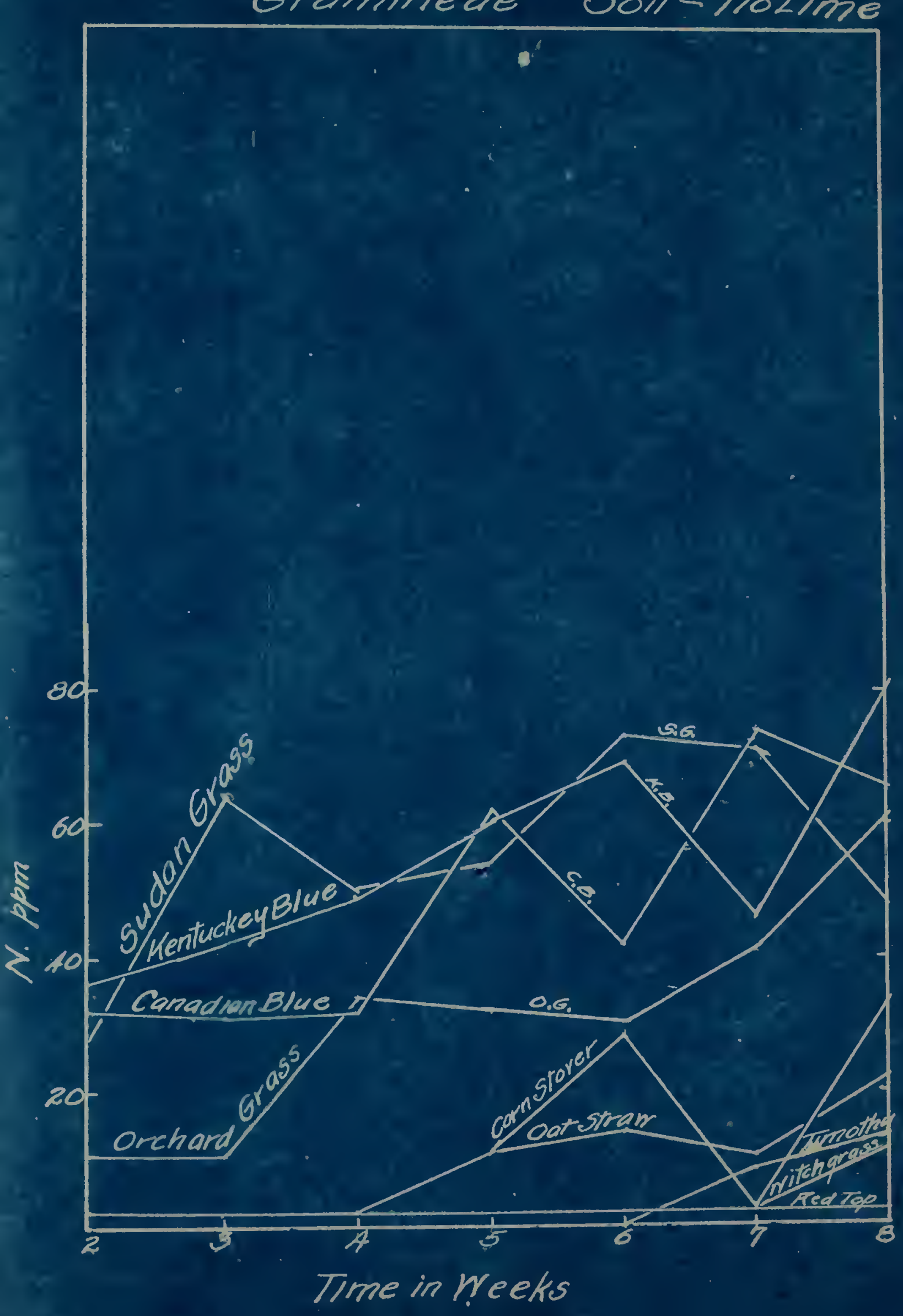


Fig. II

Compositae Soll-no Lime

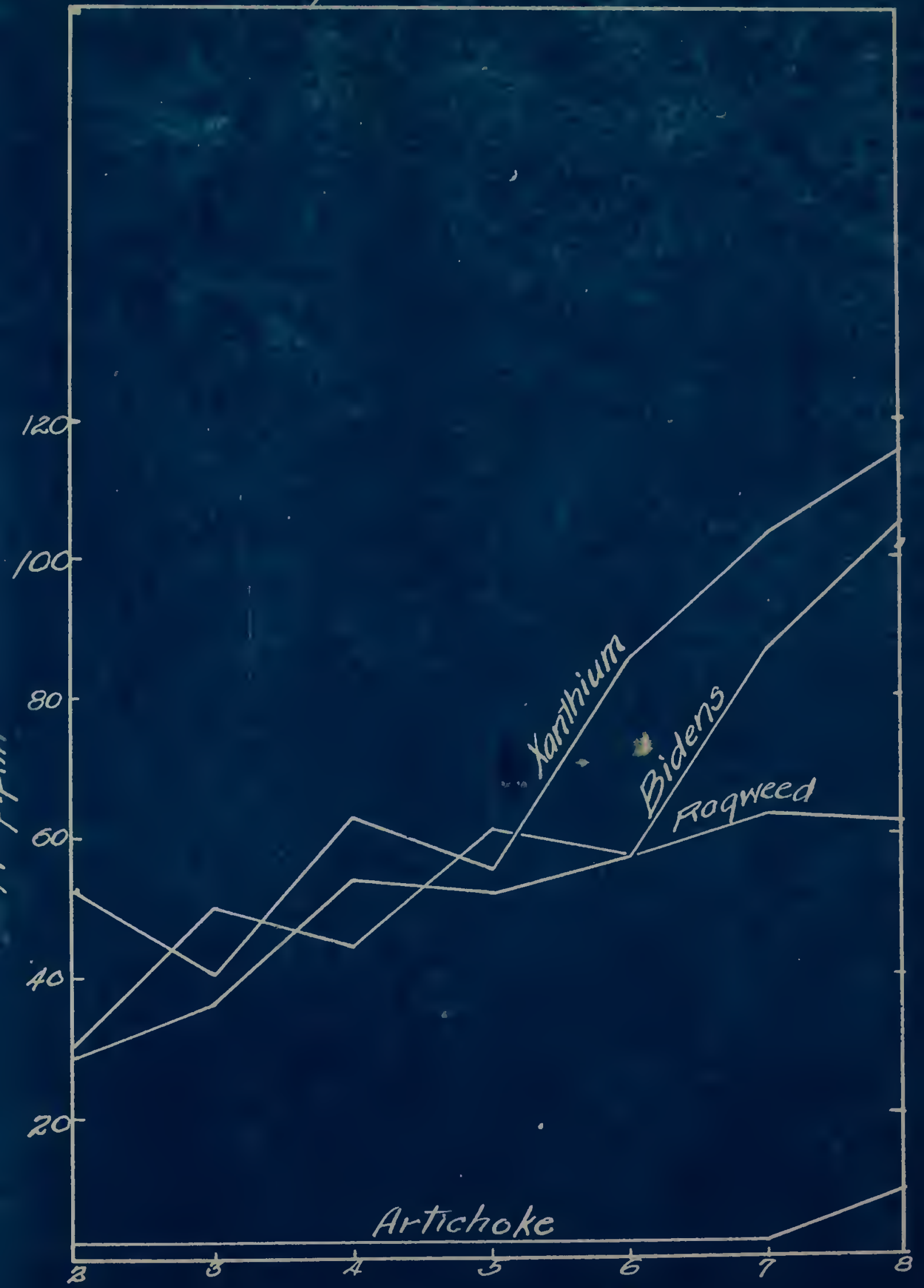

Time in Weeks 


\section{Fig. II}

Polygonaceae Soil-NoLime

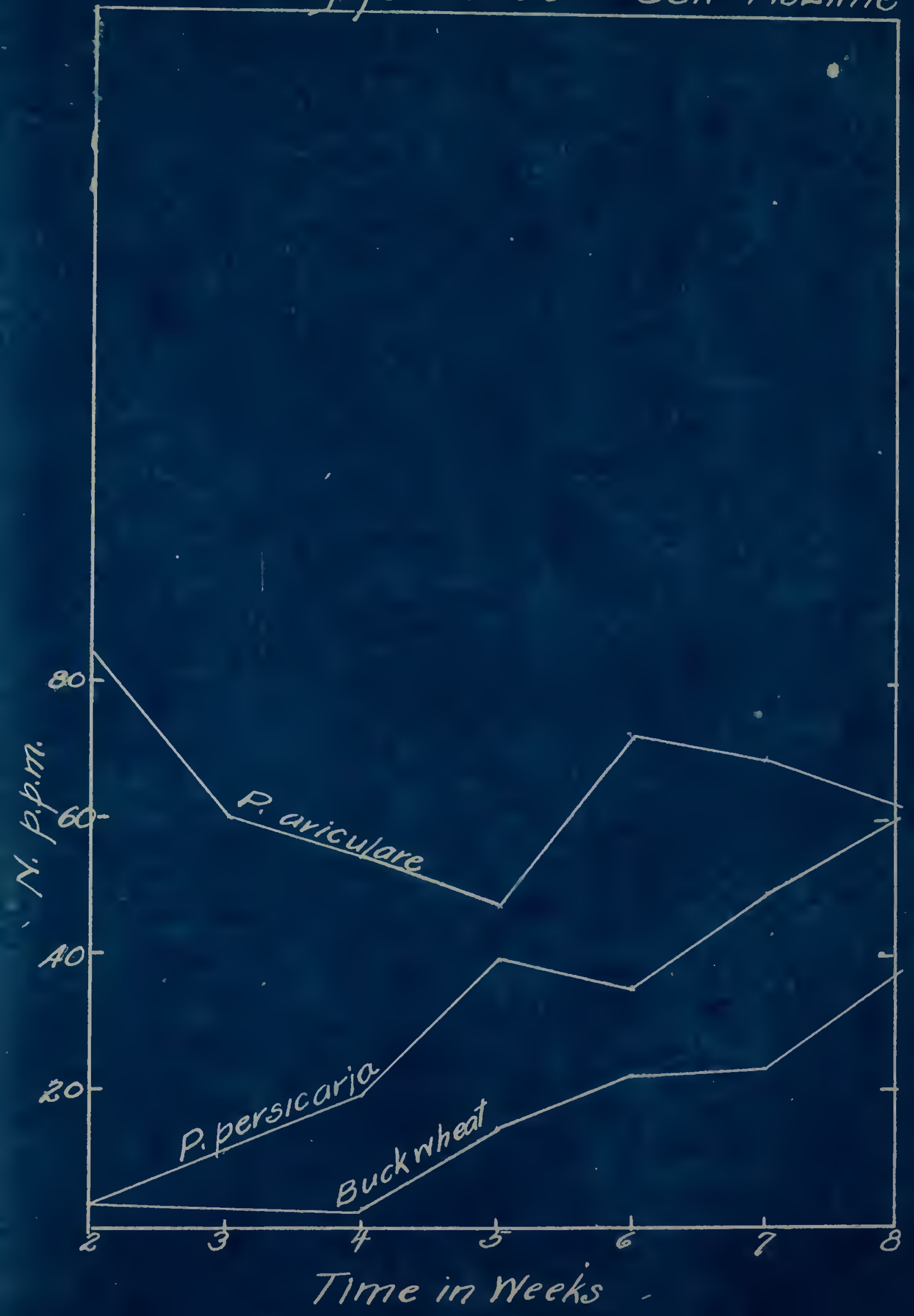




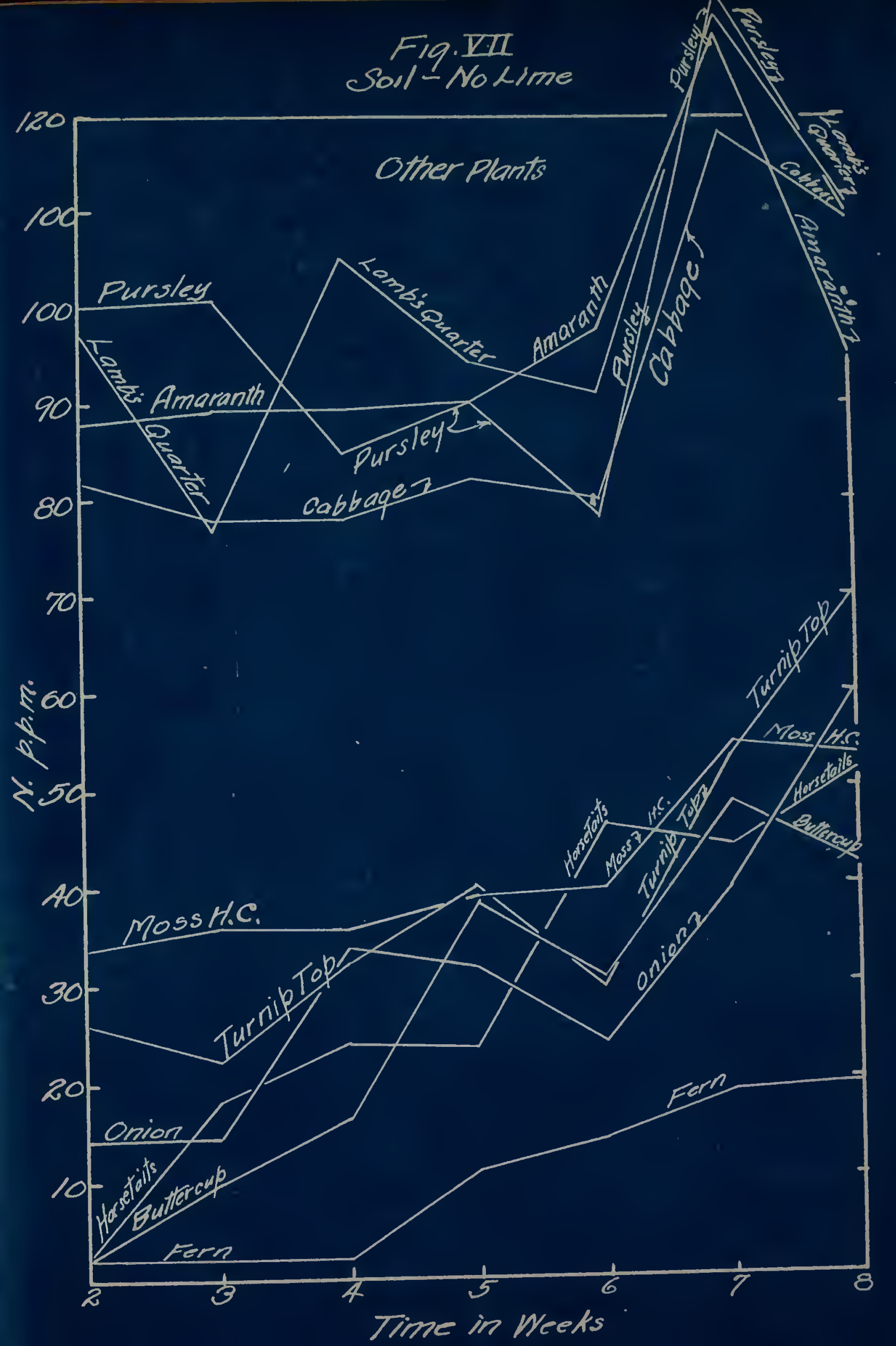


Approved by

Ildeltevs. Exiownengen

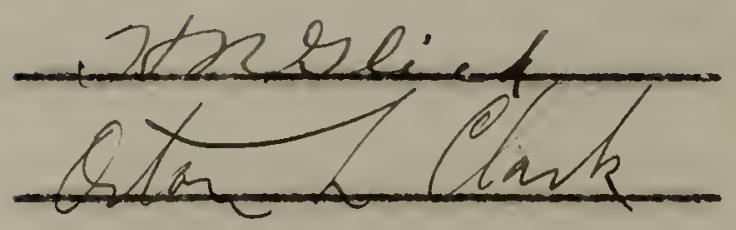

Gradusto comalsro.

Dat. Ingy 311935 


$$
\begin{aligned}
& \text { है पू山 फ़ } \\
& \because \text { แ } \\
& \text { ถู } \\
& \text { ล 式営 }
\end{aligned}
$$

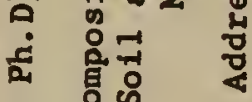

$$
\begin{aligned}
& \text { คิ } \\
& \text { को } 5 . \\
& \text { 㝴 } 0 \text { 焉 } \\
& \text { د } \\
& \text { द स्ष }
\end{aligned}
$$

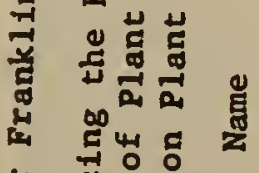

$$
\begin{aligned}
& \text { म औ } 0 \text { 。 } \\
& \text { ㅇํㅇ⿺ㄹ } \\
& \text { I }
\end{aligned}
$$

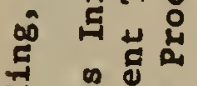

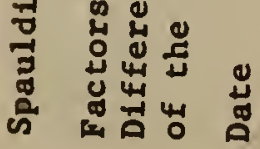




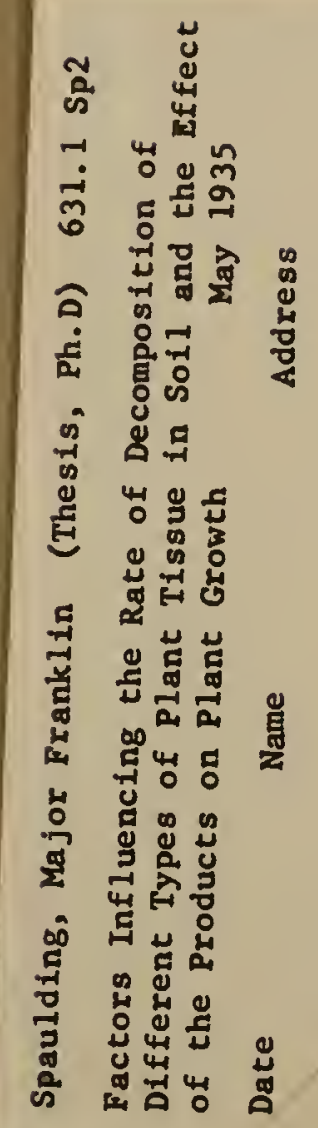


